\title{
Terpenoids, Cannabimimetic Ligands, beyond the Cannabis Plant
}

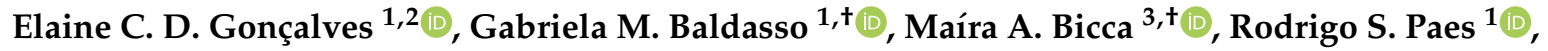 \\ Raffaele Capasso ${ }^{4, *}$ (i) and Rafael C. Dutra ${ }^{1,2, * \mathbb{C}}$ \\ 1 Laboratory of Autoimmunity and Immunopharmacology (LAIF), Department of Health Sciences, \\ Campus Araranguá, Universidade Federal de Santa Catarina, Araranguá 88906-072, Brazil; \\ elainecdalazen@gmail.com (E.C.D.G.); baldasso.gabriela@gmail.com (G.M.B.); \\ rodrigosebbenp@gmail.com (R.S.P.) \\ 2 Graduate Program of Neuroscience, Center of Biological Sciences, Campus Florianópolis, \\ Universidade Federal de Santa Catarina, Florianópolis 88040-900, Brazil \\ 3 Neurosurgery Department, Neurosurgery Pain Research institute, Johns Hopkins School of Medicine, \\ Baltimore, MD 21287, USA; bicca.ma@jhmi.edu \\ 4 Department of Agricultural Sciences, University of Naples Federico II, 80,055 Portici, Italy \\ * Correspondence: rafcapas@unina.it (R.C.); rafaelcdutra@gmail.com or rafael.dutra@ufsc.br (R.C.D.); \\ Tel.: +39-081-678664 (R.C.); +55-48-3721-21678 (R.C.D.); Fax: +55-48-3721-6448 (R.C. \& R.C.D.) \\ + These authors contributed equally to this work.
}

Academic Editor: Derek J. McPhee

Received: 29 February 2020; Accepted: 27 March 2020; Published: 29 March 2020

\begin{abstract}
Medicinal use of Cannabis sativa L. has an extensive history and it was essential in the discovery of phytocannabinoids, including the Cannabis major psychoactive compound- $\Delta$ 9-tetrahydrocannabinol $(\Delta 9-\mathrm{THC})$-as well as the G-protein-coupled cannabinoid receptors (CBR), named cannabinoid receptor type-1 (CB1R) and cannabinoid receptor type-2 (CB2R), both part of the now known endocannabinoid system (ECS). Cannabinoids is a vast term that defines several compounds that have been characterized in three categories: (i) endogenous, (ii) synthetic, and (iii) phytocannabinoids, and are able to modulate the CBR and ECS. Particularly, phytocannabinoids are natural terpenoids or phenolic compounds derived from Cannabis sativa. However, these terpenoids and phenolic compounds can also be derived from other plants (non-cannabinoids) and still induce cannabinoid-like properties. Cannabimimetic ligands, beyond the Cannabis plant, can act as CBR agonists or antagonists, or ECS enzyme inhibitors, besides being able of playing a role in immune-mediated inflammatory and infectious diseases, neuroinflammatory, neurological, and neurodegenerative diseases, as well as in cancer, and autoimmunity by itself. In this review, we summarize and critically highlight past, present, and future progress on the understanding of the role of cannabinoid-like molecules, mainly terpenes, as prospective therapeutics for different pathological conditions.
\end{abstract}

Keywords: phytocannabinoid; terpenoids; cannabinoid receptors; Cannabis plant; endocannabinoids; inflammation.

\section{The Era of Cannabis sativa, Cannabinoids, and the Endocannabinoid System: A Long Journey Traveled}

The Cannabis sativa era has a long and remarkable history dating from prehistoric Xinjiang, an ancient Chinese place, where users consumed Cannabis not only for religious/spiritual or hedonic purposes but also for its medicinal effects [1-3]. The first report of hemp medicinal use comes from Chinese medicine, around 2300 B.C. In India, Cannabis became part of the Hindu religion, being subsequently introduced to Europe between 1000 and 2000 B.C. Long after Cannabis reached 
the Americas, South America (mainly Chile) in 1545, and over 60 years later (1606), its cultivation was introduced to North America. Western medicine slowly progressed from the understanding and moderate use in the early and mid-19th century, to its wider use, based on its medicinal properties in the $20^{\text {th }}$ century. Nevertheless, due to prejudice and misinformation, the use of this plant has been marginalized, which has hindered research progress regarding its medicinal beneficial effects [1,2].

Currently, Cannabis is the most commonly cultivated, trafficked, and abused drug worldwide, potentially causing a substantial public health impact since it can alter sensory perception and induce elation and euphoria $[4,5]$. Recent use rates among the population in general show a concentration to adolescents and young adults (20 to 24 years-old), ranging from $2 \%-5 \%$ of the global population (an estimated 13 million cannabis-dependent individuals in 2010$)$; yet, the highest numbers $(\sim 10 \%-13 \%)$ are reported in North America [5-7]. A study published by Hasin and colleagues revealed a significant rise in marijuana use prevalence in 2001-2002 and 2012-2013, accompanied by a large increase of marijuana-induced disorders in this same time period [8,9]. Conversely, another study showed that Cannabis-induced disorders declined among young users during 2013-2014, in the USA [10,11]. According to United States Code, "marijuana/cannabis" comprises "all parts" of the plant Cannabis sativa L. and every compound derivative of such plant. By the year 2016, 28 states in the USA have voted to authorize or implement medicinal cannabis programs. Among these, eight states and the district of Columbia have legalized the recreational use of Cannabis [12]. In other countries, including the United Kingdom (UK), Denmark, Czech Republic, Austria, Sweden, Germany, and Spain, it is formally approved; thus, decriminalizing the therapeutic use of Cannabis and cannabis-based products [13,14]. Pioneering in Latin America, Uruguay, became the first country to legalize the sale, cultivation, and distribution of Cannabis $[15,16]$. Wilkinson and D'Souza have previously described that the medicalization and/or incorporation of Cannabis into a medicine is complex for a number of reasons, including that (i) it is a plant rather than a pharmaceutical product, and (ii) knowledge of its properties and effects is still limited [17]. However, in light of the recently and largely reported pharmacological discoveries and therapeutic benefits of Cannabis, the controlled and medicinal use of Cannabis for some pathological conditions have been enforced.

Era of cannabinoids started when Mechoulam and Gaoni isolated and characterized the main psychoactive component of Cannabis sativa, the $\Delta 9$ - tetrahydrocannabinol ( $\Delta 9$-THC). Subsequently, in 1988, Howlett's group established the presence of a specific cannabinoid receptor in the rat brain by using a tritium labeled cannabinoid [18], followed by the cloning of the cannabinoid receptor type-1 (CB1R) [19]. Then, Matsuda and coworkers (1990) described a second receptor, named the cannabinoid receptor type-2 (CB2R), which was cloned by Munro and coworkers in 1993 [18,19]. These receptors can be activated by endogenous molecules produced normally by our bodies, and likewise by external synthetic and natural molecules. The number of natural compounds identified or isolated from Cannabis sativa has been increasing in the last decade, with 565 identified substances between cannabinoids and non-cannabinoid constituents [20]. The genus Cannabis comprises closely related species, mainly, Cannabis indica, Cannabis ruderalis (identified in 1924), Cannabis sativa L., which is widely known as "hemp" and not psychoactive, as well as Cannabis sativa, which induces psychoactive effects [1]. Cannabinoids are defined as a group of molecules that modulate cannabinoid receptors (CBR) and are characterized by three varieties, such as endogenous or endocannabinoids, synthetic cannabinoids, and phytocannabinoids. The latter variety comprehends natural terpenoids or phenolic compounds derived from Cannabis sativa or other species, and will be further explored later in this review [21]. Altogether, 120 cannabinoids have been isolated from the Cannabis sativa plant and classified into 11 general types, as described below (Table 1) [20]. 
Table 1. Cannabis sativa L. constituents by chemical class.

\begin{tabular}{cc}
\hline Chemical Class & Compounds \\
\hline$\Delta$ 9-THC types & 23 \\
$\Delta 8$-THC types & 5 \\
CBG types & 16 \\
CBC types & 9 \\
CBD types & 7 \\
CBND types & 2 \\
CBE types & 5 \\
CBL types & 3 \\
CBN types & 11 \\
CBT types & 9 \\
Miscellaneous types & 30 \\
Total cannabinoids & 120 \\
Total non-cannabinoids & 445 \\
Grand Total & 565
\end{tabular}

THC, tetrahydrocannabinol; $\mathrm{CBG}$, cannabigerol; $\mathrm{CBC}$, cannabichromene; $\mathrm{CBD}$, cannabidiol; $\mathrm{CBND}$, cannabinodiol; CBE, cannabielsoin; CBL, cannabicyclol; CBN, cannabinol; CBT, cannabitriol, as previously described [20].

Pharmacologically approaching, three compounds have been isolated and identified as the most important, namely the $\Delta$ 9-tetrahydrocannabinol ( $\triangle 9$-THC), cannabidiol (CBD), and cannabinol (CBN). Relevantly, preclinical and clinical research has shown that cannabinoids, especially CBD, play key a role in different pathological conditions (Table 2).

When we talk about the era of the "endocannabinoid system", we have to keep in mind that this biological system was named over the response of its receptors to cannabinoid drugs, such as the previously mentioned and well-studied $\triangle 9$-THC and biologically active synthetic analogs, just like it has happened with the opioids in the past. In addition to its receptors, the system is highly modulated by the enzymes involved in the endogenous cannabinoids synthesis and inactivation (endocannabinoid metabolism). Furthermore, some other receptors have been reported to be activated by cannabinoid drugs and related molecules, including GPR55, GPR18, and GPR119 [40-42]. CB1R is a key component of the endocannabinoid system (ECS), since it interacts with endogenous and exogenous cannabinoids, including $\triangle 9$-THC, and it is considered the most abundant metabotropic receptor in the brain [43]. It has been cloned from humans and it is accountable for the Cannabis effects on mood, as well as negative psychotomimetic effects, including anxiety, paranoia, and dysphoria [4,44]. While CB1R plays a role as a neurotransmission regulator in different brain regions and for this reason mediates the Cannabis psychoactive effects, CB2R, in particular, mediates anti-inflammatory and immunomodulatory actions [45]. An accumulating body of evidence suggests that both CB1R and CB2R, and their ligands, play a significant role in physiologic and pathologic processes [46]. In this context, both receptors have been widely studied regarding their relevance in the modulation of immune-mediated inflammatory diseases, neuroinflammation, neurological and neurodegenerative diseases, cancer, and autoimmunity.

Beyond the CBR, mammalian tissues can both synthesize and release cannabinoid receptor ligands [44,47,48]. The era of ECS started when Devane and colleagues (1992) described for the first time, the $\mathrm{N}$-arachidonoylethanolamine molecule, named anandamide from porcine brain. Interestingly, anandamide interact to CBR and induces behavioral actions similar to the ones induced by $\triangle 9$-THC, when administered in rodents $[4,49]$. The mainly endogenous cannabinoids are the anandamide (AEA) and the 2-arachidonoyl glycerol (2-AG). It is now ordinarily accepted that the mammalian tissues contain an ECS composed by: (i) CB1R and CB2R cannabinoid receptors [19,44], (ii) endogenous cannabinoids ligands [49-51], and (iii) enzymes involved in the cannabinoids ligands synthesis and inactivation. Regarding these enzymes, the fatty acid amide hydrolase (FAAH) breaks amide bond and releases arachidonic acid and ethanolamine from AEA, and the monoacylglycerol lipase (MAGL) is responsible for a more efficiently 2-AG degradation [52]. Endocannabinoids are produced on demand from membrane lipids using the machinery of the enzymes responsible for their synthesis, 
transport, and degradation. For instance, the $\mathrm{N}$-arachidonoyl phosphatidylethanolamine (NArPE) originates a phosphatidic acid by a reaction mediated by a specific phospholipase D (NAPE-PLD); most importantly, it is hydrolyzed to AEA, in a reaction catalyzed by N-acyltransferase (NAT). The latter reaction happens out of an acyl group from the arachidonoylphosphatidylcholine (diArPC) sn-1 position converted to a phosphatidylethanolamine (PE) amino group. Following, AEA is degraded by FAAH. Synthesis of 2-AG depends on the phosphatidylinositol (PI) conversion to diacylglycerol (DAG) by the phospholipase C (PLC) enzyme, and subsequent DAG transformation to 2-AG by the action of the diacylglycerol lipase (DAGL) [53]. The ECS is involved with multiple biological functions, such as immune-mediated inflammatory and autoimmune diseases [53], as well as neuroinflammatory and neurodegenerative conditions [54]. Moreover, the ECS participates in the immune control at the CNS [55], maintaining overall "fine-tuning" of immune response balance [56], and influencing the neuroendocrine reaction to inflammation and infection [57].

Importantly, the ECS (i.e., CBR, endogenous cannabinoids, and anabolic/catabolic enzymes) are present in the cardiovascular tissues (myocardium, smooth muscle, and vascular endothelial cells), as well as in the circulating blood cells [58]. CB1R are expressed in the peripheral nervous system, including vagal afferent neurons, while CB2R are expressed in cardiomyocytes, coronary artery endothelial cells, and smooth muscle cells. For this reason, the endocannabinoid signaling exerts complex cardiac and vascular effects ranging from vasodilatation to vasoconstriction, and decreased myocardial contractility [58]. Those are important biological effects, as they could play an essential role in side effects promoted by potential molecules that are able to modulate this system. For instance, in healthy individuals, CB1R activation decreased myocardial contractility and blood pressure, possibly by peripheral inhibition of noradrenaline release from postganglionic sympathetic axons that leads to regulation of cardiac output [59]. In an opposite way, CB2R may exert a cardioprotective role associated to its immunomodulatory properties during tissue inflammation and tissue injury in cardiovascular diseases. The endogenous cannabinoids (2-AG and AEA) also have vascular effects, which are mediated by perivascular transient receptor potential vanilloid 1 (TRPV1) and transient receptor potential vanilloid 4 (TRPV4) activation in smooth muscle cells, promoting dilatory response [60]. Between the common clinical adverse effects associated with the Cannabis plant use, the increased cardiovascular activity and heart rate, as well as decreased blood pressure have been described [60]. In addition, the uses of Cannabis plant or synthetic cannabinoids have been linked to myocardial infarction, cardiomyopathy, arrhythmias, and stroke $[58,61,62]$. It occurs, possibly due to dose-dependent effects of phytocannabinoids and consequent modulation of the autonomic nervous system, at least partly via CB1R activation [60], since the CB1R antagonist Rimonabant ${ }^{\circledR}$ ameliorate the cannabis-induced tachycardia $[63,64]$. It is important to be aware of the harmful consequences that come along with the use of Cannabis plant and/or synthetic cannabinoids, as they could contribute to development of cardiovascular disorders, since the ECS has an essential role in the cardiovascular signaling.

The future, shedding light to a new era, is promising and based on the cloning of CBR associated with the possibility of manipulation of endocannabinoid levels in tissues, by using endocannabinoid enzymes-targeted pharmacology. This represents an opening of a possible gateway to the discovery and/or development of cannabimimetic ligands, beyond the Cannabis plant, which could still show therapeutic effects and possibly rule out many of the important adverse effects. A previous review has already stated that some plants, not belonging to the Cannabis genus, produce molecules chemically similar to the phytocannabinoids, named cannabimimetic ligands [65] (Figure 1). Cannabinoid-like molecules (mainly terpenes) of either plant or synthetic origin that are non-psychotropic have been studied. Terpenes and terpenoids are a widespread group of secondary metabolites found in numerous plant families, including Cannabaceae and others. Herein, we discuss the role of cannabinoid-like molecules, mainly terpenes, as prospective therapeutics for a variety of pathological conditions. 
Table 2. CBD pharmacological actions on pathological conditions.

\begin{tabular}{|c|c|c|}
\hline Research Themes & Main Findings & References \\
\hline Alzheimer's disease (AD) & $\begin{array}{l}\text { CBD prevented expression of proteins involved } \\
\text { with tau phosphorylation and AD progression. } \\
\text { CBD showed therapeutic potential for } \\
\text { AD-associated cognitive impairment. }\end{array}$ & {$[22,23]$} \\
\hline Anti-inflammatory properties & $\begin{array}{c}\text { CBD induced apoptosis and inhibited } \\
\text { lipopolysaccharide-activated NF- } \mathrm{KB} \text { and } \\
\text { interferon- } \beta / \mathrm{STAT} \text { inflammatory pathways in } \\
\text { microglial cells; CBD protected } \\
\text { oligodendrocytes progenitor cells from } \\
\text { inflammatory-induced apoptosis. }\end{array}$ & [24] \\
\hline Anxiety & $\begin{array}{l}\text { CBD modulated anxiety responses partially } \\
\text { through 5-HT }{ }_{1 \mathrm{~A}} \text {-mediated neurotransmission, } \\
\text { and demonstrated anxiolytic effects during a } \\
\text { stimulated public speaking test; CBD action on } \\
\text { limbic and paralimbic regions contributed to } \\
\text { reduced autonomic arousal and subjective } \\
\text { anxiety; CBD blocked anxiety-induced REM } \\
\text { sleep alteration through anxiolytic properties. }\end{array}$ & {$[25,26]$} \\
\hline Diabetes & $\begin{array}{l}\text { CBD showed beneficial effects on glycemic } \\
\text { control and cardiovascular dysfunction } \\
\text { during diabetes. }\end{array}$ & [27] \\
\hline Immunomodulatory effects & $\begin{array}{l}\text { CBD modulated T-cell function and apoptotic } \\
\text { signaling pathway. }\end{array}$ & [28] \\
\hline Inflammatory bowel disease (IBD) & $\begin{array}{l}\text { CBD attenuated intestinal inflammation and } \\
\text { normalized motility in patients with IBD. }\end{array}$ & [29] \\
\hline Cognitive impairments & $\begin{array}{c}\text { CBD interacted with components of emotional } \\
\text { memory processing and memory-rescuing, as } \\
\text { well as attenuated THC-induced memory } \\
\text { impairment effects. }\end{array}$ & [30] \\
\hline Neuropathic pain & $\begin{array}{l}\text { CBD inhibited chemotherapy-induced } \\
\text { neuropathic pain. }\end{array}$ & {$[31,32]$} \\
\hline Parkinson's disease (PD) & $\begin{array}{l}\text { CBD administration showed neuroprotective } \\
\text { effects during PD progression. }\end{array}$ & [33] \\
\hline Schizophrenia & $\begin{array}{l}\text { CBD showed antipsychotic-like properties in } \\
\text { schizophrenia, as well as prevented clinical } \\
\text { social dysfunction, and inhibited } \\
\text { psychomotor agitation. }\end{array}$ & {$[34,35]$} \\
\hline Seizure/Epilepsy & $\begin{array}{l}\text { CBD showed anticonvulsant effects in animal } \\
\text { models of seizure and patients with refractory } \\
\text { epilepsy. CBD was also described as safe and } \\
\text { beneficial for the treatment of } \\
\text { epileptic disorders. }\end{array}$ & [36-39] \\
\hline
\end{tabular}

CBD, cannabidiol; NF- $\mathrm{kB}$, nuclear factor kappa B; STAT, signal transducer and activator of transcription protein family; $5-\mathrm{HT}_{1 \mathrm{~A}}$, serotonin $1 \mathrm{~A}$ receptor; $\mathrm{REM}$, rapid eye movement sleep; $\mathrm{THC}$, tetrahydrocannabinol. 


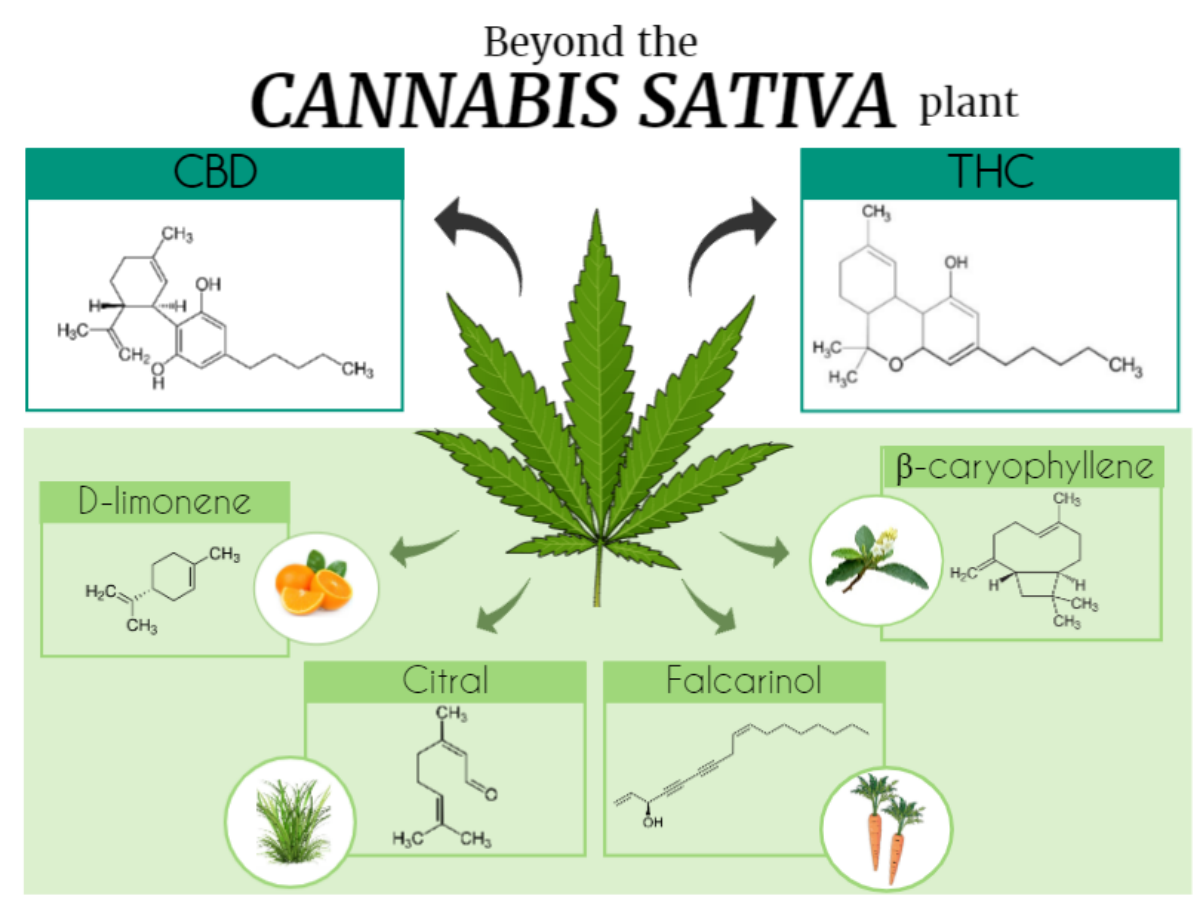

Figure 1. Beyond the Cannabis sativa plant. The Era of cannabinoids started with the description and isolation of the main Cannabis sativa psychoactive component, $\Delta 9$-tetrahydrocannabinol (THC). However, many other natural compounds were also identified, totalizing 565 substances among cannabinoids and non-cannabinoids constituents. This figure illustrates some of the Cannabis sativa compounds ( $\mathrm{D}$-limonene, $\beta$-caryophyllene, citral, and falcarinol) and its molecular structures that can be also found in other plants, such as Cordia verbenacea, lemon, Cymbopogon citratus, and carrot. CBD, cannabidiol. Figure created using the Mind the Graph platform.

\section{Cannabis Phytocannabinoids: Focus on Tetrahydrocannabinol and Cannabidiol}

The phytocannabinoid class includes more than a 100 compounds that are present in the Cannabis sativa plant [66], which interact with components of the human ECS, briefly addressed in this section. Phytocannabinoids production is dependent on plant internal factors (synthesized hormone levels, plant kind, and parts of the plant) and on external factors (humidity, light, type of soil, and temperature). The most elucidated compounds among the main phytocannabinoids are CBN, CBD, $\triangle 8$ - e $\triangle 9$-THC, cannabigerol, and cannabivarin. The $\triangle 9-T H C$ is the major psychotropic compound found in high concentrations in the Cannabis sativa plants. It is classified as a CB1R and CB2R partial agonist, showing preference for the CB1R. The agonist activity on CBR triggers adenylyl cyclase (AC) inhibition and, thereby, the ability of modulating different neurotransmitters release as dopamine, acetylcholine, glutamate, and gamma-aminobutyric acid (GABA) [66]. Of note, phytocannabinoids not only bind to CBR, but also show potential actions on different kinds of receptors, such as peroxisome proliferator-activated receptors (PPAR), glycine receptors, and the transient receptor potential (TRP) cation channels. The CBD, unlike the tetrahydrocannabinol (THC), is a non-psychotropic cannabinoid that has been widely investigated regarding its potential therapeutic use. It has been already established in the literature that CBD shows anti-inflammatory, anti-epileptic, analgesic, anxiolytic, and neuroprotective properties, as well as it can be used to mitigate Parkinson's disease (PD) symptoms [67-69]-Table 2. CBD acts as a negative allosteric modulator of CB1R [65] and as an inverse agonist in CB2R, besides being a FAAH enzyme inhibitor.

To briefly highlight, many other phytocannabinoids (e.g., cannabigerol, cannabichromene, and cannabinol) showed significant therapeutic value. The cannabigerol (CBG) showed agonist and antagonist activity on TRP channels and it was also able to produce $5-\mathrm{HT}_{1}$ and CB1R antagonism [70]. Additionally, CBG is an AEA reuptake inhibitor [71], and it showed colon anti-tumor activity by 
inhibiting transient receptor potential melastatin 8 (TRPM8) channels [72]. Relevantly, when associated with CBD, it demonstrated anti-inflammatory activity reducing tumor necrosis factor (TNF) expression and upregulating Interleukin-10 (IL-10) and Interleukin-37 (IL-37) levels [70]. Cannabichromene (CBC) showed agonist activity on CB2R [73]. Besides, it interacts with TRP channels, being suggested as a potential therapeutic resource for the treatment of pain and inflammation [71]. Lastly, CBN showed similar therapeutic properties to other phytocannabinoids, such as anticonvulsant, anti-inflammatory, and antibacterial [71]. In addition, CBN showed inhibitory activity on cyclooxygenase (COX), lipoxygenase (LOX), and P450 cytochrome enzymes [71], as well as on keratinocyte proliferation, supporting a possible potential therapeutic for psoriasis cases [74]. As it can be appreciated with the major phytocannabinoids, the wide ranges of possible interactions of these molecules with multiple targets in our body, demonstrates the magnitude and the complexity of phytocannabinoids acting in living organisms.

We just established that phytocannabinoids demonstrate different pharmacological effects, and it can get even more intriguing and complex when we focus on previous data describing that the combined use of some phytocannabinoids can possibly increase the positive effects proportionate by them. For instance, the use of CBD associated with $\triangle 9$-THC promoted downregulation of the neuroinflammatory process in animal models of multiple sclerosis (MS) [75], besides, reducing pain [76] and muscle spasticity in MS patients [75]. Importantly, CBD attenuated the psychotropic effects of THC when used in a combined form [75]. This last piece of data supports the hypothesis that CBD binds to an allosteric site on CB1R that is functionally distinct from the active site for 2-AG and THC [77]. In this same context, a recent study reported that a botanical drug preparation (BDP) was more potent than pure THC to produce antitumor responses in cell culture and animal models of breast cancer. While pure THC mainly activated CB2R and generated reactive oxygen species (ROS), the BDP modulated different targets and mechanisms of action [78]. This combined effect, observed with the association of phytocannabinoids and other compounds present in the Cannabis sativa plant, such as terpenoids, is known as the entourage effect [79] (Figure 2).

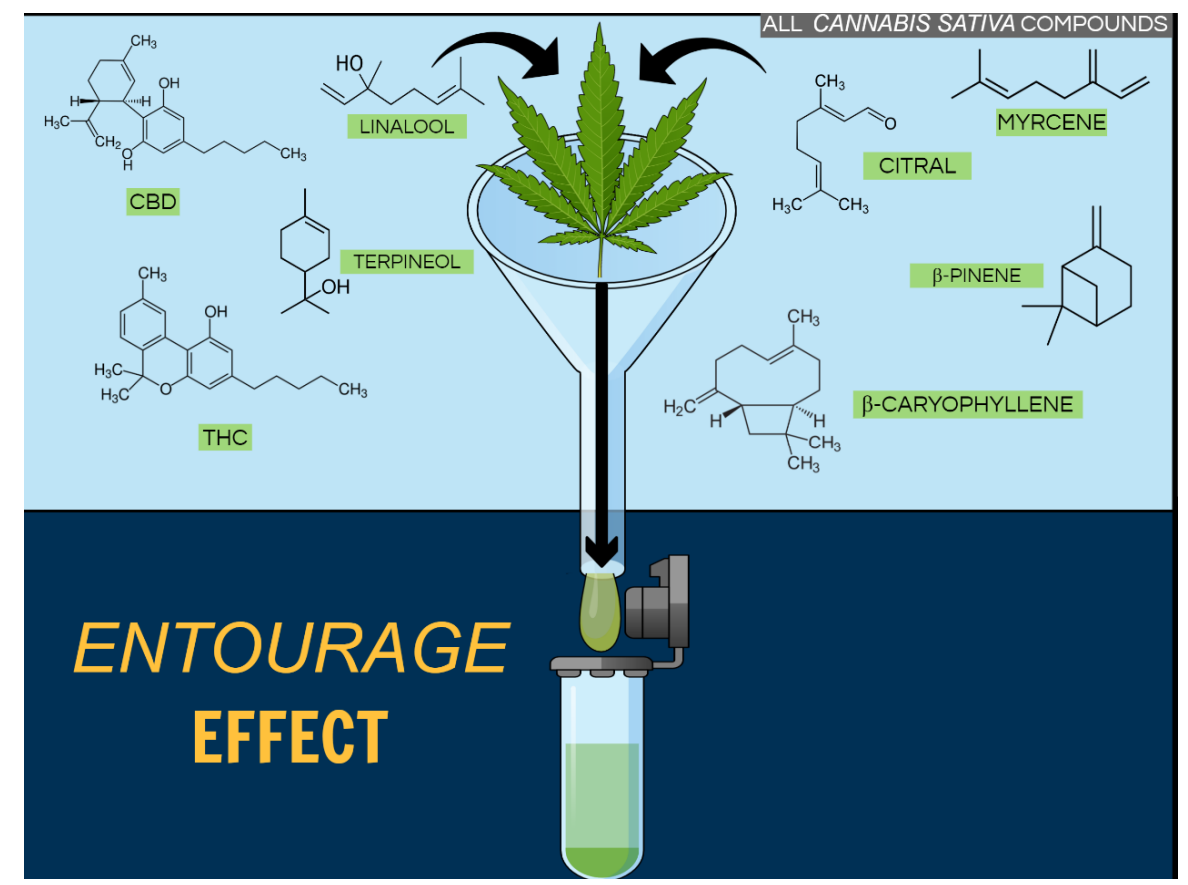

Figure 2. Entourage effect. Beyond the $\Delta 9$ - tetrahydrocannabinol ( $\triangle 9$-THC) and cannabidiol (CBD), there are many compounds present in Cannabis sativa, including terpenoids (such as linalool, terpineol, and citral), which could contribute to beneficial effects related to this plant. However, the underlying mechanism of these medicinal effects is largely unknown when molecules are associated. Figure created using the Mind the Graph platform. 


\section{Cannabis Terpenoids}

Beyond the phytocannabinoids, the Cannabis plant is able to produce a diversity of compounds. Thirty-one-years ago, Mechoulam and Ben-Shabat described what they named the "entourage effect", suggesting interactions between Cannabis "inactive" metabolites and closely related molecules could markedly increase the activity of the "primary" cannabinoids (Figure 2). From this, it was possible to hypothesize that could be a contribution of "minor cannabinoids" and Cannabis terpenoids to the plant overall pharmacological effect. Therefore, a recent study evaluated the effect of common terpenoids, by themselves and in combination with THC, in AtT20 cells expressing CB1R or CB2R. Surprisingly, none of the analyzed terpenoids modulated the THC phytocannabinoid agonist signaling. Thus, the authors suggested that if the phytocannabinoids-terpenoids entourage effect exists, it is not at the CB1R or CB2R receptor level [80]. Corroborating, when rats were submitted to an abdominal writhing model and treated only with terpenoids they demonstrated increased abdominal writhing, while the animals treated with THC showed robust analgesia, even better than the rats that received the Cannabis full extract. In this case, Cannabis antinociceptive property was linked to $\triangle 9$-THC, since terpenes alone do not alter the nociceptive behavior [81]. Using a different approach, Nandal and co-authors exposed cancerous cell lines to treatment with phytocannabinoids combined with low concentrations of co-related terpenoids. They observed increased cell mortality at ratios similar to the ones obtained with the natural plant extracts [82]. According to the authors, their results differed from Santiago et al. findings because they evaluated terpenoids without statistical correlation to THC, meaning that terpenoids concentrations in their preparations where higher than the natural-occurred in the plants $[80,82]$. Thus, the possible "entourage effect" and the positive contribution derived from the addition of terpenoids to cannabinoids could be interpreted as uncertain. However, the study of terpenoids represents an open window that goes beyond its actions (i) in the endocannabinoid system solely, or (ii) as mere phytocannabinoids passive co-authors, and even beyond the Cannabis plant.

\section{Terpenoids in and beyond the Cannabis Plant}

Cannabis contains a large number of monoterpene and sesquiterpene compounds, together called terpenoids or terpenes, which are aromatic compounds synthesized in trichomes [71]. In the plant, these compounds (i.e., more than 120 terpenes) synthesized alongside phytocannabinoids are important volatile constituents that are responsible for the plant's characteristic smell and also serve for different organic functions, such as insect repellent, repellent to herbivore attack, and attractive to pollinators [71]. Booth and Bohlmann described the terpenes- and cannabinoid-rich resin as the most valuable cannabis products, with different psychoactive and medicinal properties [83]. Studies regarding terpenoid compounds (i.e., D-limonene, $\beta$-myrcene, $\alpha$-pinene, $\alpha$-terpineol, $\beta$-pinene, $\beta$-caryophyllene, and others) have been growing in the last decades due to their large number and extensive employability $[71,84]$. However, the presence of terpenoids has not been restricted to the Cannabis sativa plant. These compounds normally occur in several other plant species, such as Mirabilis jalapa, Lithophragm glabrum, Cordia verbenacea, Eucalyptus globus, Syzygium aromaticum, Senna didymobotrya, Cymbopogon citratus, and in some Citrus genus plants, as Citrus limon and others. To date, there are more than 10,000 articles versing about phytocannabinoids or cannabimimetics, and its actions described in the literature. There are many Cannabis terpenoid compounds that are not majorly found in the Cannabis plant but are highly expressed in other plants. Its actions are varied and complex, being many compounds studied deep down to the mechanisms of action, pharmacokinetics, toxicity, and pharmacodynamics, whereas others are still to be addressed regarding these aspects. The study about terpenoids beyond the Cannabis plant has been earning ground in the research field due to the fact that they can be utilized as tools for the improvement of therapeutic research for several diseases. Herein, we can have a sense of how literature stands at this end regarding some of these compounds, and we discuss the role of terpenoids as prospective therapeutics of different pathological conditions. 


\subsection{Beta ( $\beta$ )- and $\alpha$-Caryophyllene}

Beta and alpha-Caryophyllene are the major sesquiterpenes encountered in the Cannabis plant [85]. Importantly, a comparative study showed that regardless the type of extraction used supercritical fluid extraction, steam distillation, or hydrodistillation, the major sesquiterpene compound to be extracted was $\beta$-Caryophyllene (BCP) [86]. Caryophyllenes are considered phytocannabinoids with strong affinity to CB2R but not CB1R [87], and are produced not only by Cannabis but also by a number of plants, as a mechanism of defense to insects, for instance. The vast literature describes a number of plants that contain this compounds such as Cordia verbenacea, Pterodon emarginatus, Artemisia campestris, Lantana camara, Centella asiatica, Cyanthillium cinereum, and Croton bonplandianus, just to name a few of the more than 30 species previously described. Heretofore published original articles described seven main actions to caryophyllenes. These actions are reported to be repellent, antimicrobial or antibacterial, anticancer or antiproliferative, antifungal, AChE inhibitor, antioxidant, and anti-inflammatory. Regarding the antifungal and antimicrobial action, Sabulal and co-workers showed that Zingiber nimmonii rhizome oil, which is a unique isomeric caryophyllene-rich natural source, has inhibitory activity against fungi (e.g., Candida glabrata, Candida albicans, and Aspergillus niger) as well as against both Bacillus subtilis and Pseudomonas aeruginosa bacteria [88]. More recently, a study has shown that Phoebe formosana leaf extract has antifungal activity as well; BCP being one of the active compounds identified [89]. In this same study, authors have reported that the oil exhibited cytotoxic activity against human lung, liver, and oral cancer cells while the major active compound was BCP. Corroborating, BCP was the major compound found in the tree bark essential oil from Pinus eldarica, which showed antiproliferative activity in a concentration dependent manner against MCF-7 breast cancer cell line [90]. Likewise, anticancer activity against MCF-7 cells was also reported for the essential oil of Cyperus longus mainly constituted of $\beta$ - and $\alpha$ - caryophyllenes [91]. Regarding analgesic effects, BCP has been demonstrated to attenuate paclitaxel (PTX)-induced peripheral neuropathy in mice by a mechanism dependent on mitogen-activated protein kinase (MAPK) inhibition [92]. Recently, a review has summarized, very well, the anticancer and analgesic properties of this compound [87].

The anti-inflammatory properties of BCP have been extensively shown in different mouse models of disease. Bento and co-workers have demonstrated the beneficial effect of BCP treatment in an inflammatory bowel disease mouse model, in which BCP oral treatment mitigated TNF and Interleukin-1 $\beta$ (IL-1 $\beta$ ) expression, reduced colon damage, and ameliorated disease score. To a mechanistic level, they showed these effects were at some degree dependent on peroxisome proliferator-activated receptor gamma (PPAR- $\gamma$ ) and CB2R activation [93]. In a very interesting study, Gertsch and co-workers reported that BCP selectively binds to CB2R acting as a full agonist, highlighting its potential therapeutic effects for inflammatory and painful states [94]. In an experimental autoimmune encephalomyelitis (EAE) mouse model, Alberti and co-workers have reported anti-inflammatory actions (i.e., reduced microglial activation and inducible nitric oxide synthase (iNOS) expression) of Pterodon emarginatus essential oil that is mainly enriched with BCP. Anti-inflammatory actions, in this case, contributed to attenuate neurological score and disease progression, being dependent on the control of T helper 1 (Th1) and Treg activity [95]. Later, the same authors demonstrated the effect of BCP in the experimental model of multiple sclerosis [96]. In fact, BCP extracted from Cordia verbenacea essential oil induced a markedly anti-inflammatory effect in panoply models in rats involving the attenuation of the abovementioned inflammatory molecules iNOS, TNF, and IL-2, as well as prostaglandin E2 (PGE2), and COX-2 [97]. Likewise, through anti-inflammatory pathways, BCP demonstrated a neuroprotective effect in a rat model of PD [98]. These are few very important examples of the beneficial and useful properties of caryophyllene. We agree with Sut and co-workers' point-of-view that some of the considered old molecules, as sesquiterpenes, could possibly play an important role in drug discovery towards new discoveries [99]. 


\subsection{D-Limonene}

Limonene, (4R)-1-methyl-4-prop-1-en-2-ylcyclohexene, is the most common monoterpene found in nature; for instance, in Cannabis sativa oilseed hemp named Finola and also in citrus oils, from orange, lemon, and tangerine [84]. Despite being found in Cannabis sativa, limonene does not interact with CB1R or CB2R [100]. Interestingly, D-limonene absorption and metabolism in animals is accelerated, and consequently it has a high rate of distribution and excretion. D-limonene metabolites have been detected in adipose tissue and mammary glands in a high concentration, although it has low toxicity [101]. This compound shows different pharmacological properties, which include anti-inflammatory, gastro-protective, anti-nociceptive, anti-tumor, and neuroprotective [102-104]. A recent study has demonstrated D-limonene anti-tumor activity (i.e., tumor cells decreased in proliferation and growth) in an animal model of chronic myeloid leukemia [102]. Moreover, D-limonene also showed anti-inflammatory activity by inhibiting pro-inflammatory mediators, leukocyte migration, and vascular permeability [105]. Regarding its activity on the gastrointestinal tract, there are different articles described in the literature. For instance, the same group described a gastric protection effect in rats with colon inflammation [103], and in an animal model of an ulcer induced by ethanol and indomethacin [106]. In addition, D-limonene-induced mucus production and IL-6, IL-1 $\beta$, and TNF inhibition has been previously described [107]. Corroborating this data, Wang and colleagues demonstrated that limonene affected the intestinal microbiota of mice and enhanced the relative abundance of Lactobacillus, suggesting limonene direct effects on intestinal bacteria [108].

Limonene also inhibited nociceptive behavior induced by intraperitoneal acetic acid injection and plantar formalin [109]. In a complementary way, combined administration of limonene and $\beta$-ciclodextrin inhibited hyperalgesia in a chronic musculoskeletal pain model by downregulation c-FOS expression in the spinal cord [84]. Reinforcing this information, treatment with Schinus terebinthifolius essential oil-which is highly-concentrated in limonene-showed anti-hyperalgesic and anti-depressive effects in a neuropathic pain animal model [110]. At a different point-of-view, Smeriglio and colleagues reported the antioxidant and free radical scavenging properties of Citrus lumia oil, which is highly-concentrated in monoterpenes (e.g., $48.9 \%$ D-limonene and 18.2\% linalool), suggesting an important preventive role in the genesis of oxidative stress-related pathologies [111]. In this context, a study conducted by Shin et al. showed that limonene decreased cell death, ROS levels, extracellular signal-regulated kinase phosphorylation, and overall inflammation in the brains and eyes of drosophila during A $\beta 42$-induced neurotoxicity, a model of Alzheimer's disease (AD) [104]. These and other authors have been studying limonene effects in the context of its impacts in the CNS. For instance, limonene has shown to exhibit anxiolytic effect increasing hippocampal dopamine levels and serotonin in the prefrontal cortex [75]. Considering the information above exposed, this is just one of the many compounds to be still addressed in this review that are natural and abundant in different plants, which could be used as potential therapeutics for diseases dependent on the inflammatory and oxidative-stress processes.

\subsection{Linalool}

Similar to limonene, linalool, 3,7-dimethylocta-1,6-dien-3-ol, is a monoterpene compound present in several medicinal plants and fruits, including Cannabis sativa, which has been widely used in the cosmetics and flavoring ingredients [112]. Linalool showed anti-inflammatory, anti-cancer, and anxiolytic effects [113-115]. The use of aromatherapy for the treatment of anxiety is disseminated among folk medicine. Accordingly, a study showed that linalool induced anxiolytic effects in mice by modulating GABAergic synaptic transmission [115]. Similarly to others terpenes, linalool showed anti-inflammatory activity, it prevented eosinophil migration, Th2-cytokines profile, and IgE concentration, in an asthma animal model. In addition, linalool inhibited iNOS expression, NF-kB (Nuclear factor kappa B) activation, inflammatory cells infiltration, and mucus hyper production during asthma progression [113]. Inflammation as well as oxidative stress are processes closely related to the progression of different CNS diseases, such as $\mathrm{AD}$. In this context, a recent study demonstrated that 
linalool decreased ROS and lipid peroxidation levels, as well as improved mitochondrial morphology, membrane potential, and respiration, directly reducing the cell death rate due to oxidative stress [114]. Additionally, linalool showed neuroprotective effects on A $\beta 1-40$-induced cognitive impairment in mice, which it was suggested to be mediated by inhibition of apoptosis and oxidative stress induced by A $\beta$-dependent Nrf2/HO-1 pathway activation [116].

Regarding to its potential anti-tumor activity, linalool induced apoptosis of cancer cells in vitro following the cancer-specific induction of oxidative stress, which was measured based on spontaneous hydroxyl radical production and delayed lipid peroxidation. Besides, mice in the high-dose linalool group exhibited a 55\% reduction in average xenograft tumor weight compared to the control group [117]. Linalool has also reported to be protective against ultraviolet B (UVB)-induced tumor through inhibition of inflammation and angiogenesis signaling, as well as induction of apoptosis in the mouse skin [118]. Finally, a study showed that linalool reduced paclitaxel-induced acute pain in mice, which was antagonized by the direct injection of naloxone hydrochloride, suggesting opioid signaling modulation [119]. What can be appreciated so far, and will continue to be addressed, is the general ability of different terpenes to modulate inflammation and oxidative stress through different pathways, which in turn could be very useful to shed light to novel treatments for pain, cancer, autoimmune diseases, and CNS diseases that rely greatly on the impact of these processes.

\subsection{Terpineol}

Terpineol (2-(4-methylcyclohex-3-en-1-yl)propan-2-ol) is a volatile monoterpene alcohol present in the essential oil of Cannabis sativa [120], but also in several medicinal plants, such as Punica granatum L., Rosmarinus officinalis L., and Psidium guajava L. Until this moment, there is no evidence in the literature about the interaction of terpineol with CBR. Nonetheless, this compound shows different pharmacological properties that include antinociceptive [121], antifungal [122], anti-inflammatory [123], and antidiarrheal [124]. Likewise, terpineol analgesic activity has been investigated in different animal models of pain. In this context, Oliveira and colleagues evaluated the effect of terpineol combined to $\beta$-cyclodextrin $(\beta C D)$ (family of cyclic oligosaccharides with a wide variety of practical applications, including pharmacy, medicine, and foods) in an animal model of fibromyalgia. According to the authors, $\alpha$-terpineol- $\beta C D$ complex reduced nociceptive behavior induced by a chronic muscle pain model [121]. Still, this effect was mediated by activation of descending inhibitory pain system, since analgesic effect was reversed by systemic administration of naloxone (opioid antagonist), or ondansetron (5-HT3 antagonist) [121]. Additionally, terpineol has also been demonstrated to be a safe and effective drug for control of sarcoma-induced cancer pain in mice [125]. In a complementary way, terpineol could be investigated as preventive treatment for the development of dependence and of tolerance to opioid analgesics, since it attenuated the analgesic effect of morphine [126]. Thus, it is possible to suggest that terpineol alone, or combined to other drugs, could be an interesting target for development of new analgesics to control chronic pain symptoms. Besides, it could work as adjunctive therapy to morphine in order to reduce side effects related to treatment with opioid drugs.

Terpineol showed not only antinociceptive but also neuroprotective properties, since improved memory impairment in rats exposed to transient bilateral common carotid artery occlusion. The underlying mechanisms described comprise the facilitation of LTP and suppression of lipid peroxidation, in the hippocampus [127]. In accordance, Abies koreana essential oil (terpenoids-rich oil, including terpineol) enhanced memory of mice submitted to scopolamine-induced amnesia [128]. Regarding it anti-inflammatory properties, terpineol has also been investigated for the treatment of allergic inflammation and asthma because decreased leucocyte migration and TNF levels. Furthermore, terpinen-4-ol and $\alpha$-terpineol were found to suppress the production of inflammatory mediators (e.g., NF-kB, p38, ERK, and MAPK signaling pathways) in lipopolysaccharide (LPS)-stimulated human macrophages [129]. Altogether, data supports that terpineol should be better investigated in order to characterize its neuroprotective effects found in cerebral ischemia-related memory impairment and 
possibly be extended to other neurological conditions, such as seizures, migraine, Parkinson's disease, as well as to clarify its anti-inflammatory potential.

Terpineol properties go beyond, it has previously been shown antifungal properties against Penicillium digitatum because it disrupts fungi cell wall allowing the leakage of intracellular components [130]. In agreement with this, tea tree oil's antibacterial and antifungal properties were attributed mainly to 1,8-cineol, methyl eugenol, and terpinen-4-ol [131]. Recently, Chaudhari and co-authors reported the efficacy of $\alpha$-terpineol loaded chitosan nanoemulsion ( $\alpha$-TCsNe) to control AFB1, a secondary metabolite produced by Aspergillus flavus and Aspergillus parasiticus fungi [122]. Included in miscellaneous actions, in addition to bactericidal and antifungal activities, terpineol has been recognized as algaecide [132] and by its natural repellent activity against Tribolium castaneum (H.) [133]. Finally, this monoterpenoid exhibited strong anti-proliferative activity on cancer cell lines [134], as well as it inhibited growth of tumor cells trough modulation of NF- $\mathrm{kB}$ signaling pathway [135]. Thus, it is possible hypothesize that terpineol as a versatile compound with a wide variety of beneficial effects could be a possible venue for the development of new antibiotics, antifungal, and anticancer agents.

\subsection{Terpinene}

Gamma-terpinene, 1-methyl-4-propan-2-ylcyclohexa-1,4-diene, is a monoterpene structurally similar to 1.8-cineol, being both found in the essential oils of Cannabis sativa and several other plants including the Eucalyptus genus (Myrtaceae), Cupressus cashmeriana, Lippia microphylla, Lavandula angustifolia, and Citrus myrtifolia [136-141]. Gamma-terpinene is very well described in the literature as an anti-inflammatory, antimicrobial, analgesic, and anticancer agent [136,137,142-144]. A recent study demonstrated that $\gamma$-terpinene reduced some inflammatory parameters, such as edema and inflammatory cell infiltration during tests in experimental models of inflammation, namely phlogistic agent-induced paw edema, acetic acid-induced microvascular permeability, carrageenan-induced peritonitis, and lipopolysaccharide-induced acute lung injury [145]. In addition, another study assessed the effect of $\gamma$-terpinene on pro- and anti-inflammatory macrophage production of cytokines in an animal model. The authors reported that $\gamma$-terpinene significantly increased the production of IL-10, which was dependent on PGE2 production since effects were reversed by COX-2 inhibitor nimesulide [146].

Besides the anti-inflammatory action, Assmann and colleagues described the anti-tumor activity and some of the possible underlying mechanisms of the Melaleuca alternifolia essential oil, which is composed of three major compounds terpinen-4-ol (41.98\%), $\gamma$-terpinene $(20.15 \%)$, and $\alpha$-terpinene $(9.85 \%)$, on MCF-7 breast cancer cells $[147,148]$. Authors reported $\gamma$-terpinene potential cytotoxic activity by decreasing breast cancer cells viability. Effects were observed in the early stages of apoptosis, such as increased BAX/BCL-2 genes ratio and increased cell arresting to $S$ phase of the cycle [148]. Antimicrobial activity has been tested as well; Melaleuca spp. plants demonstrated effects against a wide range of gram-positive and gram-negative bacteria, fungi, and yeasts. Impressively, Melaleuca thymifolia volatile oil exhibits higher antimicrobial activity than gentamicin and streptomycin against Staphylococcus aureus [131]. Considering the exposed, it is feasible to suggest that $\gamma$-terpinene could server as natural immunomodulatory agent with antioxidant, antimicrobial, and anticancer properties that could be useful therapeutically.

\subsection{Alpha ( $\alpha$ )- and $\beta$-Pinene}

Alpha-pinene is considered a natural compound present not only in Cannabis sativa but also in essential oils of many aromatic plants, such as Lavender angustifolia, Rosmarinus officinalis, and coniferous trees [149]. Alpha-pinene is a bicyclo[3.1.1]hept-2-ene that contains a reactive 4-membered ring structure and exhibits antioxidant, antimicrobial, anti-tumor, hypnotic, and anxiolytic activities [83,120,150-152]. There are different biological properties described to $\alpha$-pinene, as well as essential oils containing this compound have been used to treat several diseases [153], although no affinity towards CBRs 
have been described [154]. Alpha-pinene has been extensively investigated in the last years for its medicinal properties that include sedative, hypnotic, and anxiolytic [152,155]. In this context, Yang and colleagues demonstrated that $\alpha$-pinene interacts with $\mathrm{GABA}_{\mathrm{A}} /$ benzodiazepine receptors prolonging its synaptic transmission, significantly increasing the duration of non-rapid eye movement sleep (NREMS), and reducing sleep latency [151]. The beneficial effects of $\alpha$-pinene are also extended to convulsions [80,81], ischemic stroke [82], and schizophrenia [156]. Besides, $\alpha$-pinene also showed neuroprotective effects that might be related to its antioxidant properties, which include being able to decrease malondialdehyde and hydrogen peroxide levels while increasing catalase and peroxidase activity. A study has reported that rats exposed to pentylenetetrazol (PTZ)-induced convulsions submitted to $\alpha$-pinene intraperitoneal (i.p.) administration presented both initiation time delayed and reduced duration of myoclonic and tonic-clonic seizures, following PTZ injection [81]. Another study suggested that $\alpha$-pinene appears to be devoid of anticonvulsant action, since only $\beta$-pinene affected the intensity of seizures and time of death of PTZ-treated mice [80]. Further, it was suggested that $\alpha$-pinene might serve as potential therapeutics for schizophrenia since it possibly suppresses neuronal activity. However, it has also been demonstrated that inhalation of $\alpha$-pinene inhibits dizocilpine (MK-801)-induced schizophrenia-like behavioral abnormalities in mice [156]. Lastly, $\alpha$-pinene mitigated learning and memory loss induced by scopolamine in mice. The underlying mechanisms reported were increased choline acetyltransferase messenger RNA (mRNA) expression in the cortex and increased antioxidant enzyme levels (e.g., HO-1 and manganese superoxide dismutase (MnSOD)) in the hippocampus through activation of Nrf2 [157].

Beyond neuroprotection, the cytoprotective and antinociceptive properties of $\alpha$-pinene have been previously described. Regarding the former, studies were conducted using peptic ulcer, ultraviolet A radiation (UVA) irradiation, and aspirin-induced cytotoxicity models [158-160]. In details, $\alpha$-pinene was able to prevent UVA-induced loss of mitochondrial membrane potential, lipid peroxidation, DNA damages, and ROS generation [158]. Likewise, $\alpha$-pinene inhibited UVA-induced activation of pro-angiogenesis factors (e.g., iNOS and vascular endothelial growth factor (VEGF)), as well as blocked expression of inflammatory mediators (e.g., TNF, IL-6, and COX-2) and apoptotic mediators (e.g., Bax, Bcl-2, caspase-3, and caspase- 9) in mouse skin submitted to UVA-irradiation at the rate of $10 \mathrm{~J} / \mathrm{cm} 2 / \mathrm{day}$, for 10 days [159]. In contrast, $\alpha$-pinene promoted cytoxicity, and consequently cancer cells apoptosis by increasing activity of caspase-3 in human ovarian cancer cells (PA-1) [161]. In this sense, another study showed that $\alpha$-pinene was also able to inhibit human hepatoma tumor progression by inducing G2/M phase cell cycle arrest [162]. Regarding $\alpha$-pinene antinociceptive effects, it was previously demonstrated its beneficial potential in capsaicin-induced dental pulp nociception [163], xylene-induced ear edema, and formalin-inflamed hind paw models [164]. In this context, $\alpha$-pinene exhibited significantly anti-inflammatory and analgesic effects through inhibition of COX-2. Moreover, the analgesic effect of $\alpha$-pinene on capsaicin-induced pulp nociception was blocked by co-administration with bicuculline or naloxone, thus suggesting that this effect could be mediated, at least in part, by interaction with GABA-A and $\mu$-opioid receptors [163].

Related to $\alpha$-pinene, another important monoterpene present in different Cannabis sativa L. varieties is $\beta$-pinene, which can also be found in many plants essential oils and obtained commercially by distillation or by $\alpha$-pinene conversion $[165,166]$. Literature describes $\beta$-pinene antimicrobial and antioxidant activity [167], as well as its derivatives have been associated to anticancer, anticoagulation, and antimalarial effects. Additionally, $\beta$-pinene showed repellent activity against Tribolium castaneum, which is a beetle species from the Tenebrionidae family that is also a powerful invertebrate system for molecular genetics studies. Looking for the mechanism by which $\beta$-pinene mediated this repellent activity; authors reported that exposition to this compound alters the gene expression, namely Grd (which encodes GABA receptor), Ace1 (which encodes class A acetylcholinesterase) and Hiscl2 (which encodes histamine-gated chloride channel subunit 2) [168]. However, according to Pajaro-Castro and colleagues, $\beta$-pinene showed little ability to dock on proteins associated with neurotransmission process in the Tribolium castaneum [168]. Even though the $\beta$-pinene-induced repellent effect still remains to be 
fully addressed, it seems feasible to be considered that $\beta$-pinene monoterpene could act on different insect and mammalian receptors associated with neurotransmission. For instance, Guzmán-Gutiérrez and co-authors attributed to Litsea glaucescens essential oil (being $\beta$-pinene and linalool the two main active principles) antidepressant-like and sedative-like properties [169]. Posteriorly, the same group evaluated the mechanisms related to antidepressant effect of the essential oil compounds. In brief and focused on $\beta$-pinene, adult male ICR mice were pre-treated with (1S)-(-)- $\beta$-pinene $(100 \mathrm{mg} / \mathrm{kg})$ and exposed to forced swimming test (FST). Results showed that $\beta$-pinene, as well as imipramine (control drug), decreased the immobility time of mice when compared with control in the FST. Furthermore, administration of 5- $\mathrm{HT}_{1 \mathrm{~A}}$ receptor antagonist prevented the antidepressant-like of $\beta$-pinene, demonstrating that this compound could interact with the serotonergic system. Likewise, $\beta$-pinene anti-immobility effects were also prevented by propranolol ( $\beta$-receptor antagonist), neurotoxin DSP-4 (noradrenergic neurotoxin), and SCH23390 (a D1 receptor antagonist), suggesting its possible interactions with the adrenergic and dopaminergic system as well [170].

The use of $\beta$-pinene as an antitumor, as well as antiviral and antifungal agent has also been explored. Regarding the former, $\beta$-pinene-based thiazole derivatives were investigated as antineoplastic agents in vitro. Twenty-four $\beta$-pinene-based thiazole derivatives were synthesized and $5 \mathrm{~g}$ compound showed cytotoxic against three different cancer cell lines (Hela, CT-26, and SMMC-7721). Cytotoxic effect have been described to be mediated by action in the following signaling pathways: i) increased ROS activity, ii) loss of mitochondrial membrane potential, and iii) altered expression of Bax/Bcl-2, ultimately provoking cell injury and even cell death [171]. Concerning its antiviral and antifungal activity, it was shown its beneficial effects against Rhizopus stolonifer (the common bread mold) and Absidia coerulea fungi, as well as against herpes simplex virus type 1 (HSV-1), in vitro [172,173]. In fact, $\beta$-pinene reduced HSV-1 viral infectivity through interaction with free virus particles by $100 \%$ in a dose-dependent manner [174]. Similarly, $\beta$-pinene was able to reduce Candida biofilm adhesion through molecular interaction mainly with delta-14-sterol reductase-enzyme, which is related to metabolic pathway leading to cholesterol biosynthesis; thus, an effective target for antifungal drugs development $[175,176]$. Interestingly, when combined with commercial antimicrobial ciprofloxacin, both $\beta$-pinene and $\alpha$-pinene demonstrated synergistic activity against methicillin-resistant Staphylococcus aureus [177]. Summarizing, here we describe, the antioxidant, anti-inflammatory, and immunomodulatory activity of both pinenes. Importantly, the neuromodulatory role that $\alpha$-pinene and $\beta$-pinene are able to play could be used to shed light on innovative approaches to treat a variety of neurological conditions.

\section{7. $\beta$-Elemene}

$\beta$-elemene (1-methyl-1-vinyl-2,4-diisopropenyl-cyclohexane) is a derivative terpenoid found in Cannabis sativa, which may arise due to oxidation or due to thermal- or UV-induced rearrangements during processing or storage $[85,178,179]$. However, $\beta$-elemene is present not only in Cannabis sativa but also from Curcuma rhizome, and it is commonly used in traditional Chinese medicine due to its anticancer properties with no reported severe side effects [180]. In this way, this compound has been extensively studied as an anticancer agent in vitro and in vivo and has been demonstrated to be a promising drug for the treatment of a wide variety of tumors [181-186]. Among the challenges associated to cancer treatment, it is the development of multidrug resistance (MDR), which negatively impacts the effect of chemotherapy drugs, and consequently treatment success. It was previously proposed that one of the viable solutions to overcome MDR is to combine two chemotherapeutic drugs, acting synergistically to target multiple key pathways to inhibit tumor progression $[187,188]$. In this context, the combination of $\beta$-elemene with other chemotherapeutic agents (i.e., cisplatin and doxorubicin) and other therapeutic adjuvant has demonstrated great potential to inhibit tumor cells and tumor growth. According to $\mathrm{Li}$ and colleagues, $\beta$-elemene and cisplatin combined chemotherapy treatment is one of the most important approaches available for lung cancer therapy in China. Besides, the China Food and Drug Administration has approved it for the treatment of different tumors, such as brain, ovary, prostate, breast, lung, liver, and colon [189-191]. Additionally, when associated to hyperthermia $\beta$-elemene 
significantly inhibited growth of adenocarcinoma human alveolar basal epithelial cells A549 cells in a dose-dependent manner, when compared to $\beta$-elemene treatment alone [182]. Mechanistically, the exposition of A549 cells to hyperthermia plus $\beta$-elemene significantly increased mRNA expression of cyclin-dependent kinase inhibitor p21 that ultimately induced cell apoptosis [182]. Another approach to try overcoming unsuccessful chemotherapy is the nanotechnology-based drug delivery system, which could improve pharmacokinetics of chemotherapeutic agents [192]. These carriers encompass a broad range of dispersion systems (i.e., polymeric micelles, liposomes, and dendrimers) that protect against drug degradation, promote sustained release, and reduce side effects [192]. Thus, different studies evaluated the therapeutic effects of $\beta$-elemene co-loaded with chemotherapy drugs: i) cisplatin in co-loaded liposomes [193]; ii) doxorubicin (DOX) in pH-sensitive nanostructured lipid carriers (DOX/ $\beta$-elemene Hyd NLCs) [194]; iii) cabazitaxel in complex liposome [195]. In summary, these reports described that $\beta$-elemene co-loaded with lower doses of chemotherapy drugs was able to induce toxicity effects against tumor while retaining a similar therapeutic effect of the drug by itself, demonstrating synergistic effect of the compounds. Corroborating, $\beta$-elemene was also described as a radiosensitizer producing DNA damage and inhibition of DNA repair, as well as increased apoptosis. Beta-elemene was also able to inhibit the activation of the Prx1-NFkB-HIF- $1 \alpha$ axis, a key regulator whereby tumor cells adapt to radiation therapy and hypoxia [196]. Beta-elemene was also shown to inhibited monocyte chemoattractant protein-1 (MCP-1) secretion, a macrophage recruitment chemokine that contributes to cancer cells metastasis [197]. Altogether, these reports demonstrate the possible mechanisms behind $\beta$-elemene anticancer activity and suggest different ways to incorporate this compound into current clinical therapies.

Besides the very promising anticancer activity, it has been reported in the literature a variety of other beneficial effects attributed to $\beta$-elemene. $\mathrm{Li}$ and co-authors, for instance, provided evidence of $\beta$-elemene beneficial effects for atherosclerosis treatment [198]. In this study, apoE homozygous deficient mice were fed a high-fat diet during four weeks followed by $\beta$-elemene $(135 \mathrm{mg} / \mathrm{kg})$ oral gavage administration for another 12 weeks. Beta-elemene treatment significantly reduced lipid areas of atherosclerotic plaques and aortic root lesion sizes and necrotic core, basically by boosting antioxidant enzymes while decreasing inflammatory cytokines levels. [198]. In a different study, $\beta$-elemene exerted retino-protective effect by downregulation of hypoxia-inducible factor-1alpha (HIF-1 $\alpha$ ), VEGF, iNOS, and pro-inflammatory mediators during diabetes progression in a streptozotocin (STZ)-induced rat model [199]. Finally, the potential application of $\beta$-elemene in an EAE animal model was tested, in which mice were treated from day one after induction with $\beta$-elemene $(20 \mathrm{mg} / \mathrm{kg}$, i.p.) until the end of experiment. Beta-elemene reduced IFN- $\gamma$ and IL-17 levels and completely blocked EAE onset and the severity of clinical symptoms. Furthermore, $\beta$-elemene inhibited IL-17, IFN- $\gamma$, ROR- $\gamma$ T, and T-bet mRNA expression in the optic nerve of EAE mice [200]. If we start to appreciate the bigger picture, it is possible to note that as the other terpenes here described so far, $\beta$-elemene shows the ability to modulate essential biological functions, such as inflammation, oxidative stress, immunology response, cell division, as well as endothelial regulation. Beneficial properties of this compound have been studied to a mechanistically level highlighting it as a promising tool for the treatment of relevant diseases, but there are many venues that still remain to be explored.

\section{8. $\beta$-Ocimene and Camphene}

Beta-ocimene (3,7-dimethyl-1,3,6-octatriene) is acyclic monoterpene that serves as a chemical cue to attract natural enemies of phytophagous insect in several plant species, including Cannabis sativa [85]. Booth et al. demonstrated using the variety 'Finola' of Cannabis sativa oilseeds that the most abundant monoterpenes found were myrcene, $(+)-\alpha$-pinene, $(-)$-limonene, $(+)-\beta$-pinene, terpinolene, and $(E)$ - $\beta$-ocimene [85]. Farré-Armengol and colleagues demonstrated that the emissions of $\beta$-ocimene in flowers follow marked temporal and spatial patterns of emission, which are typical from floral volatile organic compound (VOC) emissions that are involved in pollinator attraction [201]. Another study reported that a monoecious cultivar (Futura 75) and a dioecious one (Finola) of Cannabis sativa 
tested in a mountain area in Alps, Italy (elevation: 1100 meters above sea level, during the growing season 2018) showed particular phytochemical behavior. For instance, inflorescences from Finola variety were characterized by higher concentrations of $\beta$-ocimene and $\alpha$-terpinolene, while $\alpha$ - and $\beta$-pinene accompanied by extremely high $\beta$-myrcene were found as predominant in Futura variety indicating that geographical provenience should be considered for a specific medicinal use of Cannabis sativa [202]. Currently, at least three beneficial properties have been described in the literature for this compound, such as antitumor, antifungal, and anticonvulsant [203,204], but mechanisms underlying the biological activity of this compound remain poorly explored.

Camphene (2,2-dimethyl-3-methylidenebicyclo(2.2.1)heptane) is a cyclic monoterpene present in Cannabis inflorescence in low titer but abundant in the essential oil of Thymus vulgaris that showed some pharmacological activities, such as expectorant, spasmolytic, and antimicrobial [205]. Camphene showed fumigant and contact toxicity against Liposcelis bostrychophila and Tribolium castaneum insects. Furthermore, it presented moderate repellent effect to T. castaneum while showed attractant effect to Liposcelis bostrychophila, [206]. Extending these observations, Benelli et al. showed that camphene inhibited Helicoverpa armigera and Spodoptera litura-key polyphagous insects pest-with a lethal dose (LC50) of 10.64 and $6.28 \mu \mathrm{g} / \mathrm{mL}$, respectively, confirming the promising potential as a botanical insecticide $[207,208]$. Altogether, these findings strongly support the use of camphene as an eco-friendly and effective insecticidal agent. More recently, Souza and co-authors evaluated the anti-Mycobacterium tuberculosis activity of 17 novel synthesized thiosemicarbazones derived from (-)-camphene, in vitro. Overall, the majority of the tested compounds exhibited significant inhibitory effects on the Mycobacterium tuberculosis growth, with minimal inhibitory concentrations (MIC) values ranged from 3.9 to $>250 \mu \mathrm{g} / \mathrm{mL}$ [209]. Although there are not as much reports about $\beta$-ocimene and camphene as was described to the other compounds here reviewed thus far, their repellent and/or insecticide activity seem to be promising.

\subsection{Nerolidol}

Nerolidol ((6E)-3,7,11-trimethyldodeca-1,6,10-trien-3-ol), also known as peruviol, is a noncyclic sesquiterpene alkene alcohol common to citrus peels, Piper claussenianum, Baccharis dracunculifolia, and Cannabis plant [210]. Previously, it was demonstrated its inhibitory effect on the growth of Leishmania braziliensis promastigotes. Importantly, ultra-structural observation of nerolidol-treated parasites by STM showed mitochondria morphological alterations in the, nuclear chromatin and flagellar pocket along with cell shrinkage. In this same study, authors demonstrated some nerolidol mechanisms of action that included loss of mitochondrial membrane potential, phosphatidylserine exposure, and DNA degradation [211]. These evidences have been further exploited and extended in a study showing that nerolidol also inhibited Leishmania amazonensis amastigotes and promastigotes (with IC50 values between 2.6 and $3.0 \mathrm{M}$ ), indicating substantial accumulation of nerolidol in the cell membrane [212]. What is also relevant to this topic are the findings demonstrating the antiparasitic activity of nerolidol in mice infected with adult stages of Schistosoma mansoni. Authors showed that nerolidol $(100,200$, or $400 \mathrm{mg} / \mathrm{kg}$ oral route) inhibited worm burden and egg production, directly associated with tegumental damage, although nerolidol showed low efficacy in mice harboring juvenile schistosomes. [213]. Substantiating, Baldissera et al. reported that nerolidol-loaded nanospheres mitigated the Trypanosoma evansi-induced cytotoxic and genotoxic effects in the rodent brain tissue during infection by upregulating NO levels; thus, preventing DNA damage and cell death [210]. Such results strongly support that nerolidol (a food additive and safe molecule) is an effective antiparasitic agent and could potentially display anti-inflammatory properties.

Regarding its potential anti-inflammatory and/or immunomodulatory activity, there are a number of studies using different cell-based and rodent models, which here we summarize. A study has shown that nerolidol blocked LPS-induced acute kidney injury by inhibiting the TLR4/NF- $\mathrm{KB}$ signaling pathway. Specifically, nerolidol markedly prevented the rise of nitrogen and creatinine levels in LPS-treated rats, and also inhibited the increase of inflammatory mediators, like TNF, IL-1 $\beta$, and 
NF- $\mathrm{BB}$ in LPS-treated NRK-52E cells [214]. Further, de Souza et al. demonstrated that nerolidol nanoencapsulation improved its anti-inflammatory effect on zymosan-induced arthritis in mice. Importantly, under the conditions assessed the formulation did not demonstrated cytotoxicity in J774 cell line [215]. A study has also shown the immunomodulatory actions of trans-nerolidol on the efficacy of doxorubicin in breast cancer cells and in a breast tumor mouse model. The compound increased doxorubicin accumulation into MDA-MB-231 and MCF7 breast cancer cells while blocked cell migration ability, in vitro [216]. In addition, nerolidol demonstrated positive effects on cyclophosphamide (CYP)-induced neuroinflammation, oxidative stress, and cognitive impairment, as well as prevented structural abnormalities in the hippocampus and cortex regions of rodents [217]. The same authors also showed using in silico approach that nerolidol binds into Nrf2 pocket domain-a key nuclear factor that regulates the expression of antioxidant proteins [217], as previously addressed in this review. In summary, authors concluded that nerolidol could be a prospective therapeutic molecule that can mitigate CYP-induced neurotoxic signs through regulation of Nrf2 and NF-kB pathway [217], although further studies are needed to confirm this neuroprotective hypothesis. Lastly, cardioprotective effects have been suggested to this compound by the same research group. They previously evaluated nerolidol cardioprotective potential as an oral treatment against CYP-induced cardiotoxicity in mice. Nerolidol inhibited cardiac inflammation, oxidative stress, cardiac apoptosis, and cardiac fibrosis, as well as ultra-structural changes leading to cardiac dysfunction induced by cyclophosphamide [218]. Corroborating, Asaikumar et al. showed that nerolidol inhibited isoproterenol-induced myocardial damage in rats [219]. Here we reviewed the most described and better-explored activities of the nerolidol, which are antiparasitic, anti-inflammatory and/or immunomodulatory, and cardioprotective.

\subsection{Euphol}

Euphol is a tetracyclic triterpene usually extracted in alcoholic preparations due to its chemical structure and therefore affinity for this solvent. Even though it is not a major compound of the Cannabis plant, one could find a few chemically structure similarities in between the euphol molecule and a couple of cannabinoids derivate, such as CBD and CBN [220]. In fact, euphol is the major compound found in different plant species from the Euphorbiaceae family [221], including Euphorbia resinifera, Euphorbia nerifolia, Euphorbia bivonae, Euphorbia umbellata, and Euphorbia tirucalli. Regarding the latest cited Euphorbia tirucalli, it is a common plant found in Brazil and by far the most studied species from the Euphorbia family in concern to its major compound: euphol. Studies on euphol chemical structure using x-ray crystallographic, Fourier transform-ion cyclotron resonance mass spectrometry, tandem mass spectrometry, and gas chromatography coupled mass spectrometry, as well as its quantitative determination in the rat plasma by liquid chromatography-tandem mass spectrometry allowed a better understanding of this compound chemical and biological behavior [222-224]. Importantly, ethnopharmacology evidences have lead and contributed to studies on the anticancer and anti-inflammatory effects of this triterpene compound, as by many years the plants from this family have been used as folk phytomedicine to treat tumors and inflammation states [221]. Although, limited studies on antiviral, antiparasitic $[225,226]$, antimicrobial, and antifungal activities of euphol have been recently reported. In our point, the most interesting aspect of a recent study is the finding that euphol can modulate the immune system by inducing cytokine production, namely IL-4, IL-3, and IL-2; thereby, influencing the Th1/Th2 balance [227]. These results could help to explain and support many of the previous described actions of euphol as an anti-inflammatory compound that will be discussed later. That being established, the two most described activities of this compound are the antitumor and the anti-inflammatory. The former is the primary and the most reported activity in the literature, being described for different Euphorbia species as well as cancer cell types while the latter is more recent; however, better studied in terms of mechanism of action. For instance, Euphorbia tirucalli-derived euphol beneficial effects against many cancer cell lines was previously tested and described. These cell lines included tumor cells from breast, head and neck, colon, glioma, prostate, epidermis, lung, bladder, melanoma, esophagus, ovary, and pancreas. Euphol cytotoxicity effect was observed against 
all cancer cell lines being very pronounced in this last cited, in which inhibited proliferation, motility, and colony formation as well [228]. Likewise, Euphorbia umbellata-derived euphol exhibited cytotoxic effects against K-562 leukemia cell line; being suggested that the main mechanism of action was apoptosis induction [229]. Other mechanisms of action proposed to euphol cytotoxic activity against breast and glioblastoma tumor cell lines included CDK2 downregulation whilst upregulates p21and p27-CDK inhibitors and autophagy induction/facilitation, respectively [230,231]. Despite of its beneficial anticancer effect, very recently a study has suggested that euphol, along with sitosterol and lupeol, could cause hepatotoxicity by inducing significant increase in alanine aminotransferase, aspartate aminotransferase, and total bilirubin levels in rats treated sub-chronically with Euphorbia bivonae extract [232]. That consists of one report showing potential toxic actions of this compound in one species while there are many other enlightening reports describing its safety and its beneficial use to treat inflammatory diseases. Reports from a group in the south of Brazil coordinated by Professor Calixto in the early 2010s have described many of this compound uses towards inflammatory diseases management, as well as possible mechanisms of action. The earliest report described its anti-inflammatory actions on a mouse model of colitis, in which this compound inhibited important inflammatory cytokine production in the colon tissue (e.g., IL-1 $\beta$, MCP-1, TNF, and IL-6); besides, the inhibition of adhesion molecules (i.e., selectins and integrins) [233]. A second study reported that euphol also inhibits inflammatory mediators and lymphocyte function-associated antigen-1 (LFA-1) integrin in the CNS, as it did in the periphery. At this time, euphol blocked Th17 myelin-specific cell migration with an overall benefic effect of reducing the severity and development of EAE, a multiple sclerosis model [234]. Later, it was described its beneficial action in a skin-inflammation mouse model induced by 12-O-tetradecanoylphorbol-13-acetate (TPA), corroborating early 2000s findings described by a Japanese group, and further extending the understanding about euphol mechanisms of action by showing that it inhibits TPA-induced protein kinase C (PKC) isoforms $[235,236]$. Later, PKC inhibition was again implicated in mediating euphol anti-inflammatory effects, as well as CB1R and CB2R in mouse models of inflammatory (e.g., PGE2-, carrageenan-, and complete Freund's Adjuvant (CFA)-induced) and neuropathic (e.g., spared nerve injury (SNI)-, paclitaxel-, and B16F10 melanoma cells-induced hypersensitivity) pain $[237,238]$. Notably, cannabinoid-mediated anti-inflammatory actions involve suppression of inflammatory cytokines, MAPKs pathway activation, and modulation of TNF and NF-KB [220], all pathways in which euphol has been demonstrated to effective. Euphol has the potential to be a very attractive anti-inflammatory molecule that works through the cannabinoid system but evidence shows that it definitely can go beyond that.

\subsection{Citral}

Citral, (2E)-3,7-dimethylocta-2,6-dienal, is the main compound of essential oils that have been used mainly in popular medicine in eastern countries. It is the major compound extracted from Cymbopogon citratus, popularly known as lemongrass, but it can also be extracted from different plants including lemon myrtle and Lindera citriodora [239]. This essential oil has been used as ingredient in foods because of its lemon-like fragrance. However, citral has gained attention in the last years due to its antimicrobial properties against Cronobacter sakazakii, a foodborne pathogen clinically associated to neonatal infections such as meningitis, septicemia, and/or necrotizing enteritis [240,241]. Its reported antimicrobial activity also extends to Staphylococcus aureus [242], Candida albicans [243], Enterobacter cloacae [244], Listeria monocytogenes [245], Aeromonas spp. [246], and Streptococcus pyogenes [247]. In this context, Yang and colleagues recently demonstrated that when combined with cinnamaldehyde, citral changed cecal microbiota composition of non-vaccinated and vaccinated broiler chickens, reducing the incidence and severity of necrotic enteritis induced by coccidiosis [239]. This is in accordance with another finding, in which citral was able to affect mouse intestinal microbiota, enhancing the relative abundance of Lactobacillus [108]. From these evidences, it was possible suggest that citral could be an important molecule for development of new antibiotic and antifungal drugs, especially because until the moment there is no evidence of relevant toxicity and side effects related to its accumulation in tissues and 
delayed excretion [248]. However, Sharma and co-authors have well highlighted that strategies are required to increase citral stability, which could facilitate its applications [249].

Citral has also been recognized by its anti-inflammatory actions in animal models of acute lung injury [250], carrageenan-induced paw edema and croton oil-induced ear edema [251], segmental glomerulosclerosis [252], pleurisy [253], and peritonitis [254]. In this context, citral inhibited LPS-induced myeloperoxidase (MPO) activity, TNF, COX-2, and IL-8 expression, as well as NF- $\mathrm{kB}$ activation via PPAR- $\gamma[254,255]$. In accordance, Shen and colleagues demonstrated that GW9662 PPAR- $\gamma$ antagonist reversed the anti-inflammatory response mediated by citral. Additionally, citral showed antioxidant properties linked to inhibition of Nrf2 pathway early activation, oxidative stress, and apoptosis [252]. More recently, Gonçalves and colleagues demonstrated that citral immunomodulatory property appears to be related to its ability to modulate CB2R, TLR4 and TLR2/dectin-1, as well as signaling pathways downstream of CBR and TLRs activation, including ATP-dependent $\mathrm{K}+$ channels [256]. The antioxidant activity of this compound was also shown when co-administrated with aspirin in rat small intestine epithelial cells, in which it regulated superoxide dismutase (SOD) and glutathione (GSH) enzymes, significantly decreasing the aspirin-induced cell death [257]. Importantly, a link between its antioxidant and antinociceptive activity has been shown in an animal model of rheumatoid arthritis. Citral has promoted a decrease in oxidative stress parameters and induced antinociceptive effects through serotonergic communication at spinal the spinal cord level [227]. In fact, the citral antinociceptive activity is among the broad variety of beneficial effects already contemplated in the literature. When combined to other analgesics as naproxen, citral increased their antinociceptive activity as well significantly inhibited naproxen-induced gastric injury [258]. However, citral showed high volatility, low solubility in water, and consequent low bioavailability, which could limit its use. One possible solution could be the combination of citral with $\beta$-cyclodextrin and hydroxypropyl- $\beta$-cyclodextrin, which in turn demonstrated antihyperalgesic and anti-inflammatory activity [253]. Here we could suggest that citral should be better investigated in order to identify its possible clinical application for the treatment of chronic pain conditions, such as peripheral neuropathy, fibromyalgia, complex regional pain syndrome (CRPS) and lumbar chronic pain.

Beyond, citral attracted scientists' attention towards its anticancer properties in a variety of cancer types, such as melanoma [259], colon cancer [260], and breast cancer [261]. Bayala and co-authors provided evidence about Cymbopogon citratus and Cymbopogon gigantescus essential oil cytotoxic activity, which have citral as its major component and significantly decreased prostate and glioblastoma cancer cell survival [262]. In addition, citral showed cytotoxic effect in non-tumoral HaCaT and tumoral A431 cells, inhibiting NO production even at the lowest concentration tested [263]. Regarding the possible mechanisms underlying its antiproliferative effects, it has been reported MARK 4 and a Ser/Thr kinase inhibition. Of note, aberrant expression or dysregulation of these proteins are linked with cancer development, such as hepatocellular carcinoma, glioma, and metastatic breast carcinomas [264,265]. Other mechanisms also comprise apoptosis induction and downregulation of the aldehyde dehydrogenase activity - a reactive protein overexpressed during cancer progression and therapy resistance [266,267]. From this, it was previously suggested that citral could work as aldehyde dehydrogenase inhibitor, and consequently as adjuvant therapy for treatment of some types of cancer [268]. In order to improve citral solubility and delivery without enhancing toxic effects in vivo, Nordin and colleagues incorporated citral into a nanostructured lipid carrier (NLC) and evaluated its in vitro anti-cancer effects. Initially, they showed that NLC as a drug delivery system for citral has the potential to sustain drug release without inducing any toxicity [269]. Then, they showed that NLC-citral regulated apoptosis, cell cycle, and metastasis signaling, all key signaling pathways related to cancer development [261]. In addition, citral was pointed as a potential effective additive to chemotherapeutic treatment $[270,271]$. Thus, when combined with hyperthermia intraperitoneal chemotherapy (HIPEC) and pirarubicin for colorectal cancer, citral increased the HIPEC efficacy by enhancing chemo-drug penetration and consequently its intracellular concentration. Furthermore, it was described a safe alternative that decreased the chemo-drug dose necessary to induce antiproliferative effect reducing 
possible side effects [271]. Still, this natural compound showed chemoprotective actions in hairless (HRS/J) mice exposed to UVB irradiation for 24 weeks, a model of skin carcinogenesis. Mechanisms involved in citral chemoprotective effect not surprisingly included oxidative stress and inflammatory cytokines inhibition and increased skin cell apoptosis [272]. It has been previously described that citral mediated antiproliferative effects through p53activation, ROS- and mitochondrial-mediated apoptosis, as well as by NO depletion and interference with cell proliferation-related signaling pathways $[259,260]$. Collectively, these set of data here gathered suggests that citral represents an important molecule for the management of different types of cancer and highlights the possibility of translational application as a novel treatment alone or in combination with other chemotherapeutic drugs.

\subsection{Celastrol}

Celastrol, 2R,4aS,6aR,6aS,14aS,14bR-10-hydroxy-2,4a,6a,6a,9,14a-hexamethyl-11-oxo-1,3,4,5,6,1 $3,14,14 \mathrm{~b}$-octahydropicene-2-carboxylic acid, is a pentacyclic triterpenoid isolated from Tripterygium wilfordii root extracts and used in traditional Chinese medicine for treatment of chronic diseases, including neurodegenerative disorders (e.g., amyotrophic lateral sclerosis, AD, and PD), type 2 diabetes, obesity, atherosclerosis, cancer, inflammatory and autoimmune diseases (e.g., systemic lupus erythematosus, multiple sclerosis, inflammatory bowel disease (IBD), psoriasis, and rheumatoid arthritis (RA) [273-275]. In fact, this natural compound has been cited in a wide variety of reports describing its antioxidant $[276,277]$, and anti-inflammatory action $[278,279]$ through inhibition of NF- $\mathrm{KB}$ signaling pathway [280]. In details, this last study demonstrated that celastrol significantly blocked COX-2 expression, IL-8 and ICAM-1, as well as IL-1 $\beta$-induced PGE2 through inhibition of NF- $\mathrm{kB}$ in a Graves' ophthalmopathy model using orbital fibroblasts [281]. Here are a few more examples of this extent literature about celastrol anti-inflammatory effects. Kim and co-authors demonstrated that celastrol inhibited LPS-stimulated NO generation, PGE2, iNOS, and COX-2, in RAW264.7 cells. In this same study, authors have reported that celastrol inhibited LPS-induced inflammatory cytokines production and also protected mice from TPA-induced ear edema by inhibiting MPO activity and the production of inflammatory mediators [278]. In addition, celastrol inhibited CFA-induced arthritis rat model via modulation of $i$ ) inflammatory cytokines (i.e., IL-17, IL-6, and IFN- $\gamma$ ) in response to the disease-related antigens, ii) IL-6/IL-17-related transcription factor STAT3, iii) cyclic citrullinatedand Bhsp65-peptides directed antibodies, and iv) MMP-9 and phospho-ERK activity, supporting the use of celastrol as an adjunct (along with conventional drugs) or alternative approach for the RA treatment [279]. Aside from the anti-inflammatory effect, also relevant are the findings demonstrating celastrol antitumor activity in a variety of human tumor cell types. Data previously suggested that celastrol represents a promising agent for the management of human tumor cell lines, such as triple negative breast cancer [282], leukemia [283,284], carcinoma [285] and lung cancer [286]. In terms of mechanisms, a study based on pharmacological and biochemical approaches has shown that celastrol inhibited cell proliferation and induce apoptosis through JNK activation, AKT suppression, and anti-apoptotic proteins downregulation [287].

Celastrol potential beneficial effects on the CNS have also been previously reported. Kiaei et al. described that celastrol improved weight loss, motor performance, and delayed the onset of motor neuron degeneration in the G93A SOD1 transgenic amyotrophic lateral sclerosis (ALS) mouse model. Celastrol increased HSP70 while mitigated iNOS, TNF, cluster of differentiation 40 (CD40), and GFAP proteins expression in the lumbar spinal cord of G93A mice [288]. Celastrol effects on HSPs have also been reported to play a key neuroprotective role in defense against misfolded proteins and aggregation-prone proteins [289]. Speaking of protein aggregation, celastrol was reported to inhibit amyloid beta aggregation, the main toxin to be accounted for AD initiation and progression [276,281]. Based on these facts, we could suggest that celastrol might represent a useful molecule to treat neurodegenerative diseases with an inflammatory background. In spite of that, celastrol use is still limited by its low water solubility, reduced oral bioavailability, and side effects reducing its therapeutic 
potential [290]. Different structure modifications or encapsulation solutions must be studied to overcome this problem.

\subsection{Falcarinol}

Falcarinol-(3R,9Z)-heptadeca-1,9-dien-4,6-diyn-3-ol)—also named panaxynol or carotatoxin is found in carrots, parsley, celery, and Panax ginseng [291]. This natural compound has been cited in a wide variety of reports describing its antineoplastic [292] and anti-inflammatory properties [293]. Besides, falcarinol has been also investigated as pharmacological tool for treatment of cardiovascular and metabolic diseases. Regarding the latter, it is know that serum high molecular weight (HMW) adiponectin values are inversely correlated with the presence of metabolic syndrome, and consequently linked to pathogenesis of insulin resistance, type 2 diabetes, and cardiovascular diseases [294]. In this sense, Takagi and colleagues demonstrated that falcarinol restored FoxO1 and increased C/EBP $\alpha$ levels (transcription factors that positively regulate adiponectin gene transcription), resulting in HMW adiponectin secretion by 3T3-L1 adipocytes treated with palmitic acid, an obesity model in vitro [295]. In addition, falcarinol also reduced endoplasmic reticulum (ER) stress, C/EBP homologous protein (CHOP) protein and ROS levels, as well as decreased inflammatory adipokine-induced MCP-1 [295]. Still in this scenario, the association of chronic inflammatory disorders and/or systemic diseases to microbiota dysbiosis has been gaining attention [296]. Importantly, a study previously showed that the beneficial effects of falcarinol and falcarindiol rely on its ability of changing the composition of low abundant gut-microbiota members. In this study, the ability of falcarinol to regulate microbiota was allied to its ability to reduce the incidence of neoplastic lesions [292]. In this cancer scenario, the mucosa-associated bacterial population as the fecal microbiota plays an important role in colon carcinogenesis, the second most commonly diagnosed cancer with high incidence, morbidity, and mortality [296,297]. That being established, Kobaek-Larson and co-authors have reported that daily diet supplementation with falcarinol and falcarindiol decreased the number of neoplastic lesions and polyps growth rate in the colon of azoxymethane-treated rats [298]. Recently, this same group demonstrated the chemopreventive effect of a special diet supplemented with falcarinol and falcarindiol on colorectal precancerous lesions in a dose-dependent manner; besides, this effect was mainly mediated by inhibition of NF- $\kappa$ B and its downstream inflammatory markers, especially COX-2 [299]. Anticarcinogenic properties of falcarinol were also demonstrated in cancer stem-like cells (CSCs), in which it played an essential role in tumor occurrence, evolution, metastasis, recurrence, and therapeutic resistance [300], as well as in non-small cell lung cancer (NSCLC) [301]. Essentially, falcarinol eliminated CSC population in NSCLC and abolished lung tumor formation in mice via HSP90 (a molecular chaperone of numerous oncoproteins) modulation [302]. Falcarinol anticancer activity also extends to leukemia [303], breast cancer [304], hepatocarcinoma [305], renal carcinoma [306], and glioma [307]. For instance, mechanisms pointed to explain its ability to induce cell cycle arrest, thus, its anticarcinogenic properties on human promyelocytic leukemia cell growth are PKC $\delta$ proteolytic cleavage, caspase-3 activation, and PARP degradation [303].

In a different context, falcarinol has been also reported to be a facilitator of type 1 hypersensitivity and atopic dermatitis [308]. On the other hand, Leonti and colleagues showed that falcarinol is not an allergen itself; however, it facilitates sensitization by other allergens, since it aggravated histamine-induced edema reactions in skin prick tests. In this study, similar effects were obtained with Rimonabant ${ }^{\circledR}$ (a CB1R inverse antagonist), implying that falcarinol-induced dermatitis could be related to CB1R antagonism in keratinocytes [291]. Despite that falcarinol has been related to allergic reactions, it has also been shown to induce anti-inflammatory responses in a couple of different models. Falcarinol promoted a reduced cell infiltration in a LPS-induced reduction in intestinal barrier context [293]. In addition, falcarinol was able to induce Nrf2-mediated resolution of inflamed macrophage-induced cardiomyocyte hypertrophy [309]. Collectively, data here presented provided information about falcarinol crucial positive effects on pathological conditions, such as metabolic diseases, cardiovascular 
diseases, and cancer. However, we consider that for the development of possible therapeutic tools underlying mechanisms as well as toxicity, and bioavailability needs be better investigated.

\subsection{Salvinorin A}

The trans-neoclerodane diterpenoid salvinorin A is a short-acting highly-selective kappa opioid receptor agonist and consequently the primary psychoactive component of Salvia divinorum (psychoactive herb used in magic-ritual contexts by Mazateca Indians in Mexico) [310]. In agreement, eight healthy hallucinogen-using adults exposed to inhalation of 16 doses of Salvia divinorum showed dose-related dissociative effects and impairments in recall/recognition memory tests [311]. Given the fact that salvinorin A highly interacts with opioid receptors, it has been considered an emerging target for next-generation of analgesics. In addition, salvinorin A showed hallucinogen effects similarly to lysergic acid diethylamide (LSD) [312,313]. Walentiny and colleagues demonstrated that salvinorin A administration induced pronounced hypolocomotion and antinociception (and to a lesser extent, hypothermia) effects in the tetrad assay, which were reverted by the administration of kappa opioid receptor (KOR) selective antagonist but not by CB1R antagonist Rimonabant ${ }^{\circledR}$ [310]. Moreover, rats exposed to sciatic nerve ligature neuropathic pain model and treated with salvinorin A directly in the insular cortex showed antinociceptive behavior. However, in contrast with Walentiny and colleagues, the analgesic effect of salvinorin $A$ in this case was reverted by selective KOR and CB1R antagonists [314]. In accordance with this finding, daily treatment with salvinorin A significantly decreased formalin-induced mechanical allodynia at days three and seven in a KOR and CB1R dependent manner, without inducing CB1R-related adverse effects. Electrophysiological experiments in vivo also showed that repeated salvinorin A treatment completely normalized neuronal activity following formalin injection, as well as it reduced formalin-evoked glial and microglial activation at the spinal cord level [315]. Nonetheless, unlike other opioid ligands, salvinorin A showed short duration of action and centrally mediated side-effects limiting its usefulness [316-318], justifying the development of new salvinorin A analogues [319]. In this context, novel analogue $\beta$-tetrahydropyran salvinorin B attenuated acute nociceptive and inflammatory pain, as well as mechanical and cold allodynia in the PTX-induced neuropathic pain model [319]. On the other hand, mesyl salvinorin B (a KOR agonist) showed moderated antinociceptive effect when compared to salvinorin $\mathrm{A}$ in warm-water $\left(50{ }^{\circ} \mathrm{C}\right)$ tail withdrawal and intraplantar formaldehyde (2\%) tests. However, it mitigated cocaine-induced hyperactivity and behavioral sensitization, without affecting aversion, sedation, anxiety, or learning and memory impairment in rats [320]. Additionally, mesyl salvinorin B alone or associated with naltrexone prevented alcohol-induced deprivation effect in mice [321], which could represent an alternative tool for treatment of alcoholism in humans. Other salvinorin A analogues, such as p38, could also be effective for the treatment of gastrointestinal inflammation, since it demonstrated anti-inflammatory and analgesic effects in an experimental model of colitis [322]. Thus, these findings support the use of novel salvinorin A-like compounds and its analogues as possible pharmacological alternatives for pain relief, control of cocaine-seeking behavior, and alcoholism, as it seems to have potent CNS and anti-inflammatory actions.

Regarding these actions, the anti-inflammatory effects associated with salvinorin A also extend to cerebral hypoxia/ischemia [323-326]. Salvinorin A attenuated brain edema and inhibited neuronal death in hippocampal CA1 region, cortex, and striatum during forebrain ischemia model [325]. According to Dong and colleagues, rats submitted to middle cerebral artery occlusion and treated with salvinorin A one hour after reperfusion showed improvement of neurological severity score when compared to control groups. Additionally, salvinorin A reduced infarct volume and effectively protected cerebral vessels after ischemia/reperfusion. Importantly, human brain microvascular endothelial cells exposed to the oxygen glucose deprivation model and treated with salvinorin A were protected against ROS damage and decreased mitochondrial function (i.e., mitochondrial morphological changes and loss of membrane potential). The latter, highly regulated by AMPK and phosphorylation mitofusin-2 expression, both upregulated in response to salvinorin A treatment [327]. Salvinorin A also mitigated 
cerebral vasospasm through endothelial nitric oxide synthase (eNOS) and NO upregulation and ET-1 downregulation. At the same time, salvinorin A inhibited AQP4 protein expression-a member of a family of channel proteins that facilitate water transport and contribute to brain edema and neuro-disorders development [326,328]. Concerning still its actions in the CNS, salvinorin A effects on the mood were also investigated and linked to anxiolytic and antidepressant properties mediated by KOR, as well as the ECS [329]. In lieu of antidepressant properties, another study associated salvinorin A to depressive-like effects through dopamine signaling inhibition in the nucleus accumbens of rats [330]. Extending, dysphoria as well as depressant-like effects of salvinorin A were attributed to KOR-linked ERK activation, which in turn promoted dopamine transporter (DAT) phosphorylation, modulating dopamine neurotransmission [331]. Recently, Keasling and colleagues evaluated the effects of salvinolin, a new semisynthetic analog of salvinorin A, with mu opioid receptor affinity. In summary, salvinolin demonstrated good oral bioavailability and showed antidepressant-like effect that was blocked by the selective $5 \mathrm{HT}_{1 \mathrm{~A}}$ antagonist WAY100635 [332]. Another derivative of salvinorin A, the 22-azido salvinorin A, also promoted an antidepressant-like effect linked to its ability of inhibiting monoamine oxidase (MAO) enzyme, as well as to its affinity for $\alpha 1 \mathrm{~A}, \alpha 1 \mathrm{~B}, \alpha 1 \mathrm{D}$ adrenergic receptors beyond KOR [333]. Here, we could sense the staggering effects of salvinorin $A$ and its analogues to modulate a variety of neurotransmission systems in the CNS.

The pharmacological effects of salvinorin A are not limited to CNS but also related to the respiratory system. Salvinorin A inhibited mast cell degranulation in the lung and consequently blocked airway hyperactivity induced by ovalbumin sensitization. Thus, the authors suggested that salvinorin A could represent a promising tool for the treatment of type 1 hypersensitivity and immune-mediated diseases [334]. Moreover, salvinorin A inhibited leukotriene production in inflammatory exudates, as well as it showed antipruritic effects mediated by KOR on compound 48/80-induced scratching behaviors in mice [335]. Findings here summarized provide evidence about the anti-inflammatory action of salvinorin A, and highlight this natural compound as a possible new tool for the treatment of inflammatory diseases.

\subsection{Pristimerin}

Pristimerin (20 $\alpha$-3-hydroxy-2-oxo-24-nor-friedela-1-10,3,5,7-tetraene-carboxylic acid-29-methyl ester) is a natural quinonoid triterpene isolated from the shrub families Celastraceae and Hippocrateaceae. It is a natural compound with cannabimimetic effects without direct interacting with CBR. For instance, pristimerin inhibited MAGL with high potency through a reversible mechanism [336]. It has been extensively investigated mainly by its inhibitory activity against cancer cell growth. Pristimerin inhibited Wnt/ $\beta$-catenin signaling via GSK3 $\beta$ activation and Wnt gene suppression in colorectal cancer cells [337]. In addition, Yousef and colleagues demonstrated pristimerin anticancer activity on colon tumor cells associated to NF- $\mathrm{B}$ signaling inhibition during the carcinogenic process [338,339]. Corroborating, this triterpenoid has also been shown to attenuated colitis-associated colon cancer by modulating NF-KB positive cells, as well as AKT/FOXO3a signaling pathway [340]. The transcription factor FOXO3 represents important target for cellular homeostasis, since it was able to regulate apoptosis, proliferation, cell cycle progression, and consequently tumorigenesis [341,342]. Pristimerin was also previously demonstrated to downregulate the PI3K/AKT/mTOR pathway playing a critical cytotoxic and anti-metastatic role in the progression of HCT-116 colorectal cancer cells in vitro and in vivo [343]. Finally, another study from Yousef and co-authors suggest that pristimerin downregulates phospho-EGF and -EGRF2 and its downstream signaling pathways, which represent a key mechanism involved in the proliferation of cancer malignant phenotypes [344,345].

The antiproliferative activity of pristimerin goes beyond colon-related cancers, it is extended to breast [346-350], melanomas [351], osteosarcoma [352], pancreatic [353,354], and prostate cancers [355-358]. Herein, we describe a few examples focusing on articles that have demonstrated potential mechanisms of action. Pristimerin anticancer activity against breast cancer cells was associated to ROS production and ASK1/JNK signaling pathway activation [346], as well as AKT 
signaling suppression [349,359]. Additionally, when combined to paclitaxel, pristimerin induced cell autophagy through inhibition of ERK1/2/p90RSK signaling-involved in cancer cell proliferation, differentiation, and migration [347,360]. Pristimerin-induced glioma overgrowth was dependent on AGO2 upregulation (a critical protein for tumorigenesis) and PTPN1 downregulation (a metabolism regulator oncogene reported to be aberrantly expressed in cancer cells) [361-363]. Furthermore, pristimerin induced glioma cell necrosis by promoting mitochondrial dysfunction, c-Jun activation, and consequently ROS overproduction [364]. It also inhibited the epidermal growth factor receptor (EGFR) protein expression during glioma cancer development $[365,366]$. Antiproliferative effects of pristimerin were investigated in oral squamous cell carcinoma cell lines as well. In this way, pristimerin showed more potent antiproliferative activity than chemotherapy drugs cisplatin and 5-fluorouracil. This effect was associated with inhibition of MAPK1/2 and PKB signaling pathways [367]. Pristimerin-induced apoptosis activity was also demonstrated in ovarian cancer cells via inhibition of AKT/NF-KB/mTOR signaling pathway [368]. Besides, few articles have reported pristimerin beneficial effects on prostate cancer. Its progression was reported to be prevented by pristimerin-induced inhibition on HIF- $1 \alpha$ and SPHK-1, which stimulates different cellular processes including cell proliferation, cell survival, and angiogenesis [355,369]. Pristimerin also induced apoptosis of prostate cancer cells through activation of mitochondrial apoptotic pathway [358], ubiquitin-proteasomal degradation [357], and inhibition of proteasomal chymotrypsin-like activity (a complex associated with cell proliferation, apoptosis, and cancer progression) [370,371]. These summarized findings provide evidences regarding pristimerin antiproliferative and cytotoxic activity as well as clinical benefits for treatment of different types of cancer.

Finally, yet importantly, Tong and co-authors showed that pristimerin inhibited arthritic and cartilage inflammation, as well as bone damage in the joints of rats submitted to adjuvant arthritis. Pristimerin inhibited inflammatory cytokines and pSTAT3 and ROR- $\gamma \mathrm{t}$ transcription factors, as well as Th17/Treg ratio favoring immune suppression [372]. In addition, anti-inflammatory properties of pristimerin included inhibition of inflammatory cytokine levels (e.g., IL-6, IL-17, IL-18, and IL-23), increase IL-10 expression, and mitigate NF- $\mathrm{KB}$ and MAPK signaling, showed during rheumatoid arthritis model and murine macrophages exposed to LPS [373]. In this sense, pristimerin seems able to interact with essential targets of the inflammatory and/or immune-mediated processes; and for this reason, it should further investigated regarding its potential ability to serve as a treatment of disorders related to the imbalance in the immune system, including autoimmune diseases.

\section{Conclusions}

The reports here highlighted showed the complex and varied pharmacology of Cannabis sativa, particularly phytocannabinoids-typical terpenophenolic compounds-as well as plenty of non-cannabinoids second metabolites, such as monoterpene, sesquiterpene, and stilbenoids. Interestingly enough, there are an increasing number of studies on cannabimimetic ligands beyond the Cannabis plant, which can act as CBR agonists or antagonist, or ECS enzyme inhibitors. They are mainly terpenes including $\beta$-caryophyllene, D-limonene, terpineol, $\beta$-elemene, euphol, pristimerin, citral, and many others (Figure 3), which can play a key role in the modulation of different pathological conditions. 


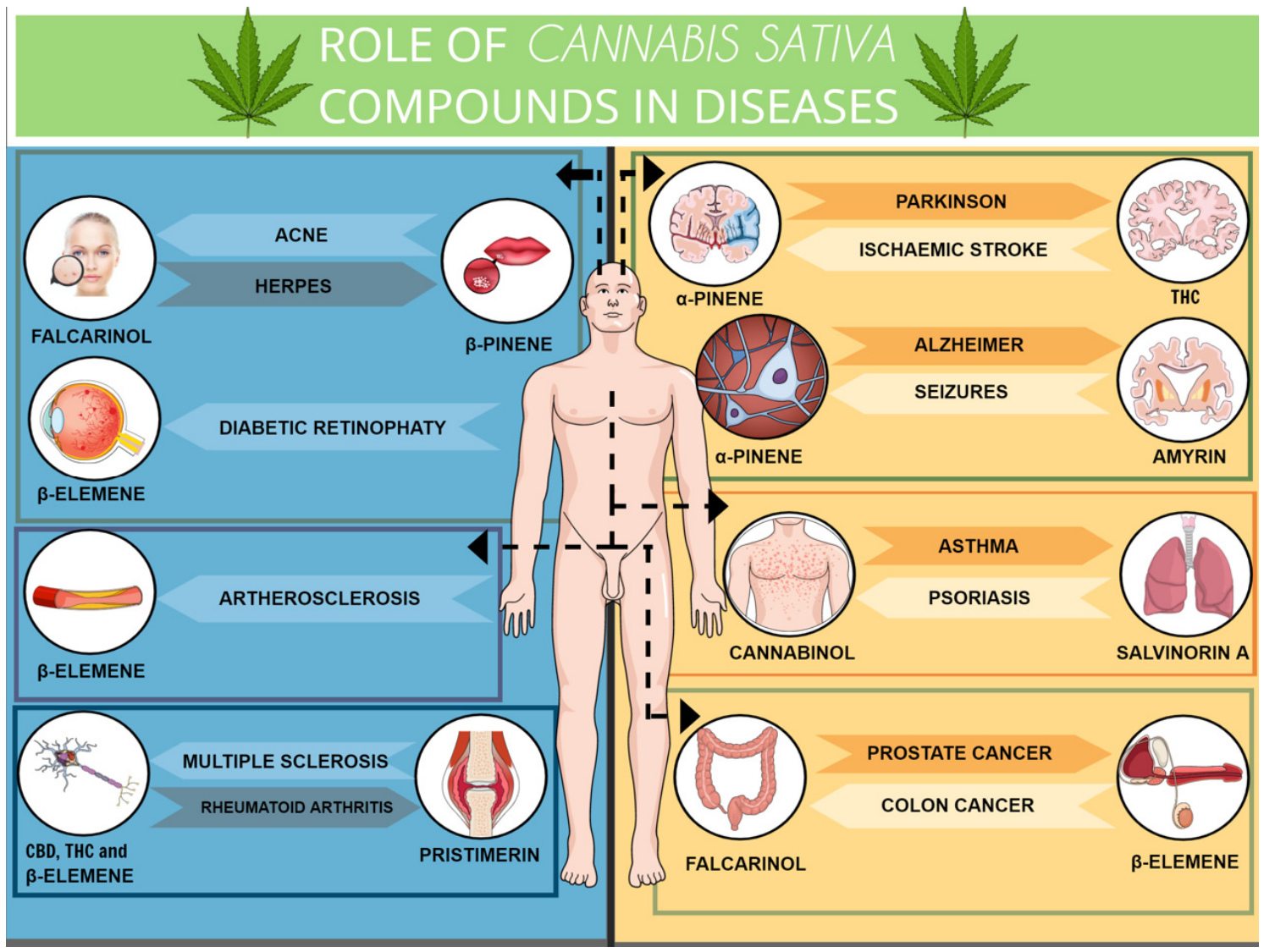

Figure 3. Role of Cannabis sativa compounds in diseases. The Cannabis sativa compounds have been proved useful for treatment of different diseases in the periphery and the CNS, as illustrated above. The CBD and THC actions in the CNS include immunomodulatory, neuroprotective, anxiolytic, and anticonvulsant, in addition to its potential effects on PD and multiple sclerosis control. Anticancer effects can be attributed to almost all Cannabis sativa compounds. This figure further illustrates the effect of terpenoids, cannabimimetic ligands, beyond the Cannabis plant in different pathological conditions, such as Herpes infection, diabetic retinopathy, psoriasis, asthma, AD, seizures, ischemic stroke, and others. Figure created using the Mind the Graph platform.

Herein, we describe that many of them share common properties, namely anti-inflammatory, analgesic, immunomodulatory, antiproliferative, and neuromodulatory. More specifically, the majority of these compounds seem to be acting on the same targets even though if in different pathological contexts (Table 3). We highlight the NF- $\mathrm{kB}$, Nfr2, PPAR, COX-2, and CDKs proteins, just to name a few. Although there are many published preclinical studies demonstrating the beneficial effects of terpenes, there is an urge for detailed pharmacokinetic and pharmacodynamics characterization of these compounds. As the cannabinoids and the Cannabis plant appear to be the most recent great hope for the treatment of uncured diseases, the particular phytocannabinoid-terpenoid interaction-the so-called entourage effect-must be continuously investigated. Besides, clinical studies are sorely needed to confirm its efficacy and safety in humans; thus, we could finally have novel potential treatments for a number of diseases that for the time being remain poorly managed. 
Table 3. The main findings about terpenoid compounds reviewed in the article.

\begin{tabular}{|c|c|}
\hline Compound & Main Findings \\
\hline$\beta$ - and $\alpha$-Caryophyllene & $\begin{array}{c}\text { Antidepressant, anxiolytic, analgesic, anticonvulsant properties. } \\
\text { Acetylcholinesterase (AChE) inhibitor. }\end{array}$ \\
\hline D-Limonene & $\begin{array}{c}\text { Anti-inflammatory, antinociceptive, gastroprotective, and } \\
\text { neuroprotective effects. }\end{array}$ \\
\hline Linalool & Anxiolytic, anticancer properties; neuroprotective effects against AD. \\
\hline Terpineol & $\begin{array}{c}\text { Analgesic activity in chronic pain conditions, such as fibromyalgia } \\
\text { and cancer pain. Adjunctive therapy to morphine adopted in order } \\
\text { to reduce its adverse effects. Preventive treatment for opioid } \\
\text { analgesic dependence and tolerance. }\end{array}$ \\
\hline Terpinene & $\begin{array}{l}\text { Analgesic, antiproliferative, anti-inflammatory, and } \\
\text { antimicrobial properties. }\end{array}$ \\
\hline$\alpha$-Pinene & $\begin{array}{l}\text { Sedative, hypnotic, anti-seizure, anxiolytic, anticancer, and analgesic } \\
\text { activities. Neuroprotective effects against memory loss. }\end{array}$ \\
\hline$\beta$-Pinene & $\begin{array}{l}\text { Antiviral, antifungal, anticancer, antimalarial, } \\
\text { antidepressant properties. }\end{array}$ \\
\hline$\beta$-Elemene & $\begin{array}{l}\text { Anticancer and hypolipidemic compound. Potential treatment for } \\
\text { demyelinating disease. }\end{array}$ \\
\hline$\beta$-Ocimene & Antiproliferative, antifungal, and anticonvulsant properties. \\
\hline Camphene & Eco-friendly botanical insecticide. \\
\hline Nerolidol & $\begin{array}{c}\text { Anti-inflammatory, anticancer, neuroprotective and } \\
\text { antimicrobial effects. }\end{array}$ \\
\hline Euphol & Antiviral, antiparasitic, antimicrobial, and antifungal activities. \\
\hline Citral & $\begin{array}{c}\text { Antimicrobial, anti-inflammatory, antinociceptive, and } \\
\text { anticancer properties. }\end{array}$ \\
\hline Celastrol & Anti-inflammatory and anticancer compound. \\
\hline Falcarinol & $\begin{array}{l}\text { Possible tool for treatment of cardiovascular diseases. } \\
\text { Anticarcinogenic compound. }\end{array}$ \\
\hline Salvinorin A & $\begin{array}{l}\text { Psychoactive herb; anxiolytic, anti-inflammatory, and antidepressant } \\
\text { effects. Alternative treatment for control of cocaine-seeking behavior } \\
\text { and alcoholism. Promising tool for treatment of type } 1 \\
\text { hypersensitivity. }\end{array}$ \\
\hline Pristimerin & MGL inhibitor; anticancer and anti-metastatic effects. \\
\hline
\end{tabular}

AD, Alzheimer's disease; MGL, monoacylglycerol lipase.

Author Contributions: Conceptualization, E.C.D.G., G.M.B., M.A.B., R.S.P., R.C.D.; Writing original draft preparation, E.C.D.G., G.M.B., M.A.B., R.S.P., R.C.D.; Review and Editing, M.A.B., E.C.D.G., G.M.B., R.C., R.C.D. All authors have read and agreed to the published version of the manuscript.

Funding: This research received no external funding.

Acknowledgments: The authors would like to thank the Laboratory of Autoimmunity and Immunopharmacology (LAIF) team member's-Universidade Federal de Santa Catarina-Graduate Program of Neuroscience, who have assisted with the literature analysis. R.C.D. is recipient of a research productivity fellowship supported by the Brazilian funding agency CNPq.

Conflicts of Interest: The authors declare no conflict of interest.

\section{Abbreviations}

AC: Adenylyl Cyclase; AChE, Acetylcholinesterase; AFB1, Aflatoxin B1; Ago2, Argonaute 2; ALS, Amyotrophic lateral sclerosis; AMPK, AMP-activated protein kinase; apoE, Apolipoprotein E; A $\beta$, Amyloid-beta; BAX, BCL2 associated X protein; BCL2, B-cell lymphoma 2 protein; CD40, Cluster of differentiation 40; CHOP, C/EBP 
Homologous Protein; COX, Cyclooxygenase; COX-2, Cyclooxygenase-2; CNS, Central nervous system; CYP, Cyclophosphamide; DAT-1, Dopamine transporter; EAE, Experimental autoimmune encephalomyelitis; EGFR, Epidermal growth factor receptor; eNOS, Endothelial nitric oxide synthase; ET-1, Endothelin-1; FOXO3, Forkhead box O3; GABA, Gamma-aminobutyric acid; GPR18, G protein-coupled receptor 18; GPR55, G protein-coupled receptor 55; GPR119, G protein-coupled receptor 19; GSH, Glutathione; GSK-3 $\beta$, Glycogen synthase kinase-3 beta; HIF-1 $\alpha$, Hypoxia-inducible factor - 1alpha; HMW, High molecular weight; HO1, Heme oxygenase-1; Hsp90, Heat shock protein 90; HSPs, Heat-shock proteins; i.p., Intraperitoneal; IBD, Inflammatory bowel disease; IFN- $\gamma$, Interferon-gamma; IgE, Immunoglobulin E; IL-1 $\beta$, Interleukin -1 $\beta$; IL-2, Interleukin - 2; IL-3, Interleukin - 3; IL-4, Interleukin - 4; IL-6, Interleukin - 6; IL-8, Interleukin - 8; IL-10, Interleukin - 10; IL-12, Interleukin 12; IL-17, Interleukin - 17; IL-37, Interleukin - 37; iNOS, Inducible nitric oxide synthase; LFA-1, Lymphocyte function-associated antigen-1; LPS, Lipopolysaccharide; LOX, Lipoxygenase; LTP, Long term potentiation; MAO, Monoamine oxidase; MAPK, Mitogen-activated protein kinase; MARK4, Microtubule Affinity-Regulating Kinase 4; MCP-1, Monocyte chemoattractant protein-1; MMP-9, Matrix metallopeptidase - 9; MnSOD, Manganese superoxide dismutase; MPO, Myeloperoxidase; mTOR, Mammalian target of rapamycin; NF- $\mathrm{B}$, Nuclear factor kappa B; NO, Nitric oxide; NREMS, Non-rapid eye movement sleep; p90RSK, 90 kDa ribosomal S6 kinase; PARP, Poly ADP-ribose polymerase; PGE2, Prostaglandin E2; PI3K, Phosphoinositide 3-kinase; PKB, Protein kinase B; PKC, Protein kinase C; PPAR, Peroxisome proliferator-activated receptors; PPAR- $\gamma$, Peroxisome proliferator-activated receptor gamma; pSTAT3, Phosphorylated STAT3; PTX, Paclitaxel; PTZ, Pentylenetetrazole; RA, Rheumatoid arthritis; ROR- $\gamma \mathrm{t}$, Retinoid-related orphan receptor- $\gamma \mathrm{t}$; ROS, Reactive oxygen species; SNI, Spared nerve injury; SOD1, Superoxide dismutase - 1; SPHK1, Sphingosinekinase 1; Th1, T helper 1; Th2, T helper 2; TLR4, Toll-Like Receptor 4; TPA, 12-O-tetradecanoylphorbol-13-acetate; TRPM8, Transient receptor potential melastatin 8; TRP, Transient receptor potential; TRPV1, Transient receptor potential vanilloid 1; TRPV4, Transient receptor potential vanilloid 4; TNF, Tumor necrosis factor; UVA, Ultraviolet A radiation; VEGF, Vascular endothelial growth factor.

\section{References}

1. Di Marzo, V.; Bifulco, M.; De Petrocellis, L. The endocannabinoid system and its therapeutic exploitation. Nat. Reviews. Drug Discov. 2004, 3, 771-784. [CrossRef] [PubMed]

2. Rubin, V. Cannabis and Culture; Mouton: The Hague, The Netherlands, 1975.

3. Guy, G.W.; Whittle, B.A.; Robson, P. The Medicinal Uses of Cannabis and Cannabinoids; Pharmaceutical Press: London, UK, 2004.

4. Pacher, P.; Batkai, S.; Kunos, G. The endocannabinoid system as an emerging target of pharmacotherapy. Pharmacol. Rev. 2006, 58, 389-462. [CrossRef] [PubMed]

5. Russell, C.; Rueda, S.; Room, R.; Tyndall, M.; Fischer, B. Routes of administration for cannabis use-Basic prevalence and related health outcomes: A scoping review and synthesis. Int. J. Drug Policy 2018, 52, 87-96. [CrossRef] [PubMed]

6. Azofeifa, A.; Mattson, M.E.; Schauer, G.; McAfee, T.; Grant, A.; Lyerla, R. National Estimates of Marijuana Use and Related Indicators-National Survey on Drug Use and Health, United States, 2002-2014. Morb. Mortal. Wkly. Rep. Surveill. Summ. 2016, 65, 1-28. [CrossRef] [PubMed]

7. Degenhardt, L.; Ferrari, A.J.; Calabria, B.; Hall, W.D.; Norman, R.E.; McGrath, J.; Flaxman, A.D.; Engell, R.E.; Freedman, G.D.; Whiteford, H.A.; et al. The global epidemiology and contribution of cannabis use and dependence to the global burden of disease: Results from the GBD 2010 study. PLoS ONE 2013, 8, e76635. [CrossRef]

8. Hasin, D.S.; Saha, T.D.; Kerridge, B.T.; Goldstein, R.B.; Chou, S.P.; Zhang, H.; Jung, J.; Pickering, R.P.; Ruan, W.J.; Smith, S.M.; et al. Prevalence of Marijuana Use Disorders in the United States between 2001-2002 and 2012-2013. JAMA Psychiatry 2015, 72, 1235-1242. [CrossRef]

9. Hasin, D.S.; Sarvet, A.L.; Cerda, M.; Keyes, K.M.; Stohl, M.; Galea, S.; Wall, M.M. US Adult Illicit Cannabis Use, Cannabis Use Disorder, and Medical Marijuana Laws: 1991-1992 to 2012-2013. JAMA Psychiatry 2017, 74, 579-588. [CrossRef]

10. Han, B.; Compton, W.M.; Blanco, C.; Jones, C.M. Trends in and correlates of medical marijuana use among adults in the United States. Drug Alcohol Depend. 2018, 186, 120-129. [CrossRef]

11. Han, B.; Compton, W.M.; Jones, C.M.; Blanco, C. Cannabis Use and Cannabis Use Disorders among Youth in the United States, 2002-2014. J. Clin. Psychiatry 2017, 78, 1404-1413. [CrossRef]

12. Hill, K.P. Cannabis Use and Risk for Substance Use Disorders and Mood or Anxiety Disorders. JAMA 2017, 317, 1070-1071. [CrossRef] 
13. Belackova, V.; Stefunkova, M. Interpreting the Czech drug decriminalization: The glass is half full-Response to Cerveny, J., Chomynova, P., Mravcik, V., \& van Ours, J.C. (2017). Cannabis decriminalization and the age of onset of cannabis use. Int. J. Drug Policy 2018, 52, 102-105. [PubMed]

14. Belackova, V.; Wilkins, C. Consumer agency in cannabis supply-Exploring auto-regulatory documents of the cannabis social clubs in Spain. Int. J. Drug Policy 2018, 54, 26-34. [CrossRef] [PubMed]

15. Room, R. Legalizing a market for cannabis for pleasure: Colorado, Washington, Uruguay and beyond. Addiction 2014, 109, 345-351. [CrossRef] [PubMed]

16. Room, R. Cannabis legalization and public health: Legal niceties, commercialization and countercultures. Addiction 2014, 109, 358-359. [CrossRef]

17. Wilkinson, S.T.; D'Souza, D.C. Problems with the medicalization of marijuana. JAMA 2014, 311, $2377-2378$. [CrossRef]

18. Devane, W.A.; Dysarz, F.A., 3rd; Johnson, M.R.; Melvin, L.S.; Howlett, A.C. Determination and characterization of a cannabinoid receptor in rat brain. Mol. Pharmacol. 1988, 34, 605-613.

19. Matsuda, L.A.; Lolait, S.J.; Brownstein, M.J.; Young, A.C.; Bonner, T.I. Structure of a cannabinoid receptor and functional expression of the cloned cDNA. Nature 1990, 346, 561-564. [CrossRef]

20. ElSohly, M.A.; Radwan, M.M.; Gul, W.; Chandra, S.; Galal, A. Phytochemistry of Cannabis sativa L. Prog. Chem. Org. Nat. Prod. 2017, 103,1-36.

21. Russo, E.; Guy, G.W. A tale of two cannabinoids: The therapeutic rationale for combining tetrahydrocannabinol and cannabidiol. Med. Hypotheses 2006, 66, 234-246. [CrossRef]

22. Esposito, G.; Scuderi, C.; Valenza, M.; Togna, G.I.; Latina, V.; De Filippis, D.; Cipriano, M.; Carratu, M.R.; Iuvone, T.; Steardo, L. Cannabidiol reduces Abeta-induced neuroinflammation and promotes hippocampal neurogenesis through PPARgamma involvement. PLoS ONE 2011, 6, e28668. [CrossRef]

23. Martin-Moreno, A.M.; Reigada, D.; Ramirez, B.G.; Mechoulam, R.; Innamorato, N.; Cuadrado, A.; de Ceballos, M.L. Cannabidiol and other cannabinoids reduce microglial activation in vitro and in vivo: Relevance to Alzheimer's disease. Mol. Pharmacol. 2011, 79, 964-973. [CrossRef] [PubMed]

24. Mecha, M.; Torrao, A.S.; Mestre, L.; Carrillo-Salinas, F.J.; Mechoulam, R.; Guaza, C. Cannabidiol protects oligodendrocyte progenitor cells from inflammation-induced apoptosis by attenuating endoplasmic reticulum stress. Cell Death Dis. 2012, 3, e331. [CrossRef] [PubMed]

25. Shannon, S.; Opila-Lehman, J. Effectiveness of Cannabidiol Oil for Pediatric Anxiety and Insomnia as Part of Posttraumatic Stress Disorder: A Case Report. Perm. J. 2016, 20, 16-005. [CrossRef] [PubMed]

26. Marinho, A.L.; Vila-Verde, C.; Fogaca, M.V.; Guimaraes, F.S. Effects of intra-infralimbic prefrontal cortex injections of cannabidiol in the modulation of emotional behaviors in rats: Contribution of 5HT(1)A receptors and stressful experiences. Behav. Brain Res. 2015, 286, 49-56. [CrossRef] [PubMed]

27. Jadoon, K.A.; Ratcliffe, S.H.; Barrett, D.A.; Thomas, E.L.; Stott, C.; Bell, J.D.; O'Sullivan, S.E.; Tan, G.D. Efficacy and Safety of Cannabidiol and Tetrahydrocannabivarin on Glycemic and Lipid Parameters in Patients With Type 2 Diabetes: A Randomized, Double-Blind, Placebo-Controlled, Parallel Group Pilot Study. Diabetes Care 2016, 39, 1777-1786. [CrossRef] [PubMed]

28. Dhital, S.; Stokes, J.V.; Park, N.; Seo, K.S.; Kaplan, B.L. Cannabidiol (CBD) induces functional Tregs in response to low-level T cell activation. Cell. Immunol. 2017, 312, 25-34. [CrossRef]

29. Krohn, R.M.; Parsons, S.A.; Fichna, J.; Patel, K.D.; Yates, R.M.; Sharkey, K.A.; Storr, M.A. Abnormal cannabidiol attenuates experimental colitis in mice, promotes wound healing and inhibits neutrophil recruitment. J. Inflamm. 2016, 13, 21. [CrossRef]

30. Norris, C.; Loureiro, M.; Kramar, C.; Zunder, J.; Renard, J.; Rushlow, W.; Laviolette, S.R. Cannabidiol Modulates Fear Memory Formation through Interactions with Serotonergic Transmission in the Mesolimbic System. Neuropsychopharmacol. Off. Publ. Am. Coll. Neuropsychopharmacol. 2016, 41, 2839-2850. [CrossRef]

31. Genaro, K.; Fabris, D.; Arantes, A.L.F.; Zuardi, A.W.; Crippa, J.A.S.; Prado, W.A. Cannabidiol Is a Potential Therapeutic for the Affective-Motivational Dimension of Incision Pain in Rats. Front. Pharmacol. 2017, 8, 391. [CrossRef]

32. Harris, H.M.; Sufka, K.J.; Gul, W.; ElSohly, M.A. Effects of Delta-9-Tetrahydrocannabinol and Cannabidiol on Cisplatin-Induced Neuropathy in Mice. Planta Med. 2016, 82, 1169-1172. [CrossRef]

33. Peres, F.F.; Levin, R.; Suiama, M.A.; Diana, M.C.; Gouvea, D.A.; Almeida, V.; Santos, C.M.; Lungato, L.; Zuardi, A.W.; Hallak, J.E.; et al. Cannabidiol Prevents Motor and Cognitive Impairments Induced by Reserpine in Rats. Front. Pharmacol. 2016, 7, 343. [CrossRef] [PubMed] 
34. Peres, F.F.; Diana, M.C.; Suiama, M.A.; Justi, V.; Almeida, V.; Bressan, R.A.; Zuardi, A.W.; Hallak, J.E.; Crippa, J.A.; Abilio, V.C. Peripubertal treatment with cannabidiol prevents the emergence of psychosis in an animal model of schizophrenia. Schizophr. Res. 2016, 172, 220-221. [CrossRef] [PubMed]

35. Renard, J.; Loureiro, M.; Rosen, L.G.; Zunder, J.; de Oliveira, C.; Schmid, S.; Rushlow, W.J.; Laviolette, S.R. Cannabidiol Counteracts Amphetamine-Induced Neuronal and Behavioral Sensitization of the Mesolimbic Dopamine Pathway through a Novel mTOR/p70S6 Kinase Signaling Pathway. J. Neurosci. Off. J. Soc. Neurosci. 2016, 36, 5160-5169. [CrossRef] [PubMed]

36. Devinsky, O.; Cross, J.H.; Wright, S. Trial of Cannabidiol for Drug-Resistant Seizures in the Dravet Syndrome. N. Engl. J. Med. 2017, 377, 699-700. [CrossRef] [PubMed]

37. Hosseinzadeh, M.; Nikseresht, S.; Khodagholi, F.; Naderi, N.; Maghsoudi, N. Cannabidiol Post-Treatment Alleviates Rat Epileptic-Related Behaviors and Activates Hippocampal Cell Autophagy Pathway Along with Antioxidant Defense in Chronic Phase of Pilocarpine-Induced Seizure. J. Mol. Neurosci. MN 2016, 58, 432-440. [CrossRef] [PubMed]

38. Kaplan, E.H.; Offermann, E.A.; Sievers, J.W.; Comi, A.M. Cannabidiol Treatment for Refractory Seizures in Sturge-Weber Syndrome. Pediatr. Neurol. 2017, 71, 18-23 e2. [CrossRef] [PubMed]

39. Patel, R.R.; Barbosa, C.; Brustovetsky, T.; Brustovetsky, N.; Cummins, T.R. Aberrant epilepsy-associated mutant Nav1.6 sodium channel activity can be targeted with cannabidiol. Brain J. Neurol. 2016, 139 Pt 8 , 2164-2181. [CrossRef]

40. Ibsen, M.S.; Connor, M.; Glass, M. Cannabinoid CB1 and CB2 Receptor Signaling and Bias. Cannabis Cannabinoid Res. 2017, 2, 48-60. [CrossRef]

41. McHugh, D.; Page, J.; Dunn, E.; Bradshaw, H.B. Delta(9) -Tetrahydrocannabinol and N-arachidonyl glycine are full agonists at GPR18 receptors and induce migration in human endometrial HEC-1B cells. Br. J. Pharmacol. 2012, 165, 2414-2424. [CrossRef]

42. Pertwee, R.G.; Howlett, A.C.; Abood, M.E.; Alexander, S.P.; Di Marzo, V.; Elphick, M.R.; Greasley, P.J.; Hansen, H.S.; Kunos, G.; Mackie, K.; et al. International Union of Basic and Clinical Pharmacology. LXXIX. Cannabinoid receptors and their ligands: Beyond $\mathrm{CB}(1)$ and $\mathrm{CB}(2)$. Pharmacol. Rev. 2010, 62, 588-631. [CrossRef]

43. Davis, K.D.; Flor, H.; Greely, H.T.; Iannetti, G.D.; Mackey, S.; Ploner, M.; Pustilnik, A.; Tracey, I.; Treede, R.D.; Wager, T.D. Brain imaging tests for chronic pain: Medical, legal and ethical issues and recommendations. Nat. Rev. Neurol. 2017, 13, 624-638. [CrossRef] [PubMed]

44. Howlett, A.C.; Barth, F.; Bonner, T.I.; Cabral, G.; Casellas, P.; Devane, W.A.; Felder, C.C.; Herkenham, M.; Mackie, K.; Martin, B.R.; et al. International Union of Pharmacology. XXVII. Classification of cannabinoid receptors. Pharmacol. Rev. 2002, 54, 161-202. [CrossRef] [PubMed]

45. Ashton, J.C.; Glass, M. The cannabinoid CB2 receptor as a target for inflammation-dependent neurodegeneration. Curr. Neuropharmacol. 2007, 5, 73-80. [CrossRef] [PubMed]

46. Rom, S.; Persidsky, Y. Cannabinoid receptor 2: Potential role in immunomodulation and neuroinflammation. J. Neuroimmune Pharmacol. Off. J. Soc. Neuroimmune Pharmacol. 2013, 8, 608-620. [CrossRef]

47. Pertwee, R.G. The pharmacology of cannabinoid receptors and their ligands: An overview. Int. J. Obes. 2006, 30 (Suppl. 1), S13-S18. [CrossRef]

48. Pertwee, R.G. Pharmacological actions of cannabinoids. Handb. Exp. Pharmacol. 2005, 168, 1-51. [CrossRef]

49. Devane, W.A.; Hanus, L.; Breuer, A.; Pertwee, R.G.; Stevenson, L.A.; Griffin, G.; Gibson, D.; Mandelbaum, A.; Etinger, A.; Mechoulam, R. Isolation and structure of a brain constituent that binds to the cannabinoid receptor. Science 1992, 258, 1946-1949. [CrossRef]

50. Mechoulam, R.; Ben-Shabat, S.; Hanus, L.; Ligumsky, M.; Kaminski, N.E.; Schatz, A.R.; Gopher, A.; Almog, S.; Martin, B.R.; Compton, D.R.; et al. Identification of an endogenous 2-monoglyceride, present in canine gut, that binds to cannabinoid receptors. Biochem. Pharmacol. 1995, 50, 83-90. [CrossRef]

51. Sugiura, T.; Kondo, S.; Sukagawa, A.; Nakane, S.; Shinoda, A.; Itoh, K.; Yamashita, A.; Waku, K. 2-Arachidonoylglycerol: A possible endogenous cannabinoid receptor ligand in brain. Biochem. Biophys. Res. Commun. 1995, 215, 89-97. [CrossRef]

52. Pertwee, R.G. Receptors and channels targeted by synthetic cannabinoid receptor agonists and antagonists. Curr. Med. Chem. 2010, 17, 1360-1381. [CrossRef]

53. Goncalves, E.D.; Dutra, R.C. Cannabinoid receptors as therapeutic targets for autoimmune diseases: Where do we stand? Drug Discov. Today 2019, 24, 1845-1853. [CrossRef] [PubMed] 
54. Di Iorio, G.; Lupi, M.; Sarchione, F.; Matarazzo, I.; Santacroce, R.; Petruccelli, F.; Martinotti, G.; Di Giannantonio, M. The endocannabinoid system: A putative role in neurodegenerative diseases. Int. J. High Risk Behav. Addict. 2013, 2, 100-106. [CrossRef] [PubMed]

55. Wolf, S.A.; Tauber, S.; Ullrich, O. CNS immune surveillance and neuroinflammation: Endocannabinoids keep control. Curr. Pharm. Des. 2008, 14, 2266-2278. [CrossRef] [PubMed]

56. Cabral, G.A.; Ferreira, G.A.; Jamerson, M.J. Endocannabinoids and the Immune System in Health and Disease. Handb. Exp. Pharmacol. 2015, 231, 185-211. [PubMed]

57. De Laurentiis, A.; Araujo, H.A.; Rettori, V. Role of the endocannabinoid system in the neuroendocrine responses to inflammation. Curr. Pharm. Des. 2014, 20, 4697-4706. [CrossRef]

58. Pacher, P.; Steffens, S.; Hasko, G.; Schindler, T.H.; Kunos, G. Cardiovascular effects of marijuana and synthetic cannabinoids: The good, the bad, and the ugly. Nat. Re. Cardiol. 2018, 15, 151-166. [CrossRef]

59. Ashton, J.C.; Smith, P.F. Cannabinoids and cardiovascular disease: The outlook for clinical treatments. Curr. Vasc. Pharmacol. 2007, 5, 175-185. [CrossRef]

60. Ho, W.S.V.; Kelly, M.E.M. Cannabinoids in the Cardiovascular System. Adv. Pharmacol. 2017, 80, 329-366.

61. Wolff, V.; Jouanjus, E. Strokes are possible complications of cannabinoids use. Epilepsy Behav. EB 2017, 70 Pt $B, 355-363$. [CrossRef]

62. Singh, A.; Saluja, S.; Kumar, A.; Agrawal, S.; Thind, M.; Nanda, S.; Shirani, J. Cardiovascular Complications of Marijuana and Related Substances: A Review. Cardiol. Ther. 2018, 7, 45-59. [CrossRef]

63. Lu, Y.; Anderson, H.D. Cannabinoid signaling in health and disease. Can. J. Physiol. Pharmacol. 2017, 95, 311-327. [CrossRef] [PubMed]

64. Huestis, M.A.; Boyd, S.J.; Heishman, S.J.; Preston, K.L.; Bonnet, D.; Le Fur, G.; Gorelick, D.A. Single and multiple doses of rimonabant antagonize acute effects of smoked cannabis in male cannabis users. Psychopharmacology 2007, 194, 505-515. [CrossRef] [PubMed]

65. Kumar, A.; Premoli, M.; Aria, F.; Bonini, S.A.; Maccarinelli, G.; Gianoncelli, A.; Memo, M.; Mastinu, A. Cannabimimetic plants: Are they new cannabinoidergic modulators? Planta 2019, 249, 1681-1694. [CrossRef] [PubMed]

66. Solymosi, K.; Kofalvi, A. Cannabis: A Treasure Trove or Pandora's Box? Mini Rev. Med. Chem. 2017, 17, 1223-1291. [CrossRef] [PubMed]

67. Morales, P.; Hurst, D.P.; Reggio, P.H. Molecular Targets of the Phytocannabinoids: A Complex Picture. Prog. Chem. Org. Nat. Prod. 2017, 103, 103-131.

68. Campos, A.C.; Fogaca, M.V.; Sonego, A.B.; Guimaraes, F.S. Cannabidiol, neuroprotection and neuropsychiatric disorders. Pharmacol. Res. 2016, 112, 119-127. [CrossRef]

69. Crivelaro do Nascimento, G.; Ferrari, D.P.; Guimaraes, F.S.; Del Bel, E.A.; Bortolanza, M.; Ferreira-Junior, N.C. Cannabidiol increases the nociceptive threshold in a preclinical model of Parkinson's disease. Neuropharmacology 2020, 163, 107808. [CrossRef]

70. Mammana, S.; Cavalli, E.; Gugliandolo, A.; Silvestro, S.; Pollastro, F.; Bramanti, P.; Mazzon, E. Could the Combination of Two Non-Psychotropic Cannabinoids Counteract Neuroinflammation? Effectiveness of Cannabidiol Associated with Cannabigerol. Medicina 2019, 55, 747. [CrossRef]

71. Russo, E.B.; Marcu, J. Cannabis Pharmacology: The Usual Suspects and a Few Promising Leads. Adv. Pharmacol. 2017, 80, 67-134.

72. Borrelli, F.; Pagano, E.; Romano, B.; Panzera, S.; Maiello, F.; Coppola, D.; De Petrocellis, L.; Buono, L.; Orlando, P.; Izzo, A.A. Colon carcinogenesis is inhibited by the TRPM8 antagonist cannabigerol, a Cannabis-derived non-psychotropic cannabinoid. Carcinogenesis 2014, 35, 2787-2797. [CrossRef]

73. Udoh, M.; Santiago, M.; Devenish, S.; McGregor, I.S.; Connor, M. Cannabichromene is a cannabinoid CB2 receptor agonist. Br. J. Pharmacol. 2019, 176, 4537-4547. [CrossRef] [PubMed]

74. Wilkinson, J.D.; Williamson, E.M. Cannabinoids inhibit human keratinocyte proliferation through a non-CB1/CB2 mechanism and have a potential therapeutic value in the treatment of psoriasis. J. Dermatol. Sci. 2007, 45, 87-92. [CrossRef] [PubMed]

75. Al-Ghezi, Z.Z.; Miranda, K.; Nagarkatti, M.; Nagarkatti, P.S. Combination of Cannabinoids, Delta9Tetrahydrocannabinol and Cannabidiol, Ameliorates Experimental Multiple Sclerosis by Suppressing Neuroinflammation Through Regulation of miRNA-Mediated Signaling Pathways. Front. Immunol. 2019, 10, 1921. [CrossRef] [PubMed] 
76. Haupts, M.; Vila, C.; Jonas, A.; Witte, K.; Alvarez-Ossorio, L. Influence of Previous Failed Antispasticity Therapy on the Efficacy and Tolerability of THC:CBD Oromucosal Spray for Multiple Sclerosis Spasticity. Eur. Neurol. 2016, 75, 236-243. [CrossRef] [PubMed]

77. Laprairie, R.B.; Bagher, A.M.; Kelly, M.E.; Denovan-Wright, E.M. Cannabidiol is a negative allosteric modulator of the cannabinoid CB1 receptor. Br. J. Pharmacol. 2015, 172, 4790-4805. [CrossRef] [PubMed]

78. Blasco-Benito, S.; Seijo-Vila, M.; Caro-Villalobos, M.; Tundidor, I.; Andradas, C.; Garcia-Taboada, E.; Wade, J.; Smith, S.; Guzman, M.; Perez-Gomez, E.; et al. Appraising the "entourage effect": Antitumor action of a pure cannabinoid versus a botanical drug preparation in preclinical models of breast cancer. Biochem. Pharmacol. 2018, 157, 285-293. [CrossRef] [PubMed]

79. Russo, E.B. The Case for the Entourage Effect and Conventional Breeding of Clinical Cannabis: No "Strain," No Gain. Front. Plant Sci. 2018, 9, 1969. [CrossRef]

80. Felipe, C.F.B.; Albuquerque, A.M.S.; de Pontes, J.L.X.; de Melo, J.I.V.; Rodrigues, T.; de Sousa, A.M.P.; Monteiro, A.B.; Ribeiro, A.; Lopes, J.P.; de Menezes, I.R.A.; et al. Comparative study of alpha- and beta-pinene effect on PTZ-induced convulsions in mice. Fundam. Clin. Pharmacol. 2019, 33, 181-190. [CrossRef]

81. Zamyad, M.; Abbasnejad, M.; Esmaeili-Mahani, S.; Mostafavi, A.; Sheibani, V. The anticonvulsant effects of Ducrosia anethifolia (Boiss) essential oil are produced by its main component alpha-pinene in rats. Arq. De Neuro-Psiquiatr. 2019, 77, 106-114. [CrossRef]

82. Khoshnazar, M.; Bigdeli, M.R.; Parvardeh, S.; Pouriran, R. Attenuating effect of alpha-pinene on neurobehavioural deficit, oxidative damage and inflammatory response following focal ischaemic stroke in rat. J. Pharm. Pharmacol. 2019, 71, 1725-1733. [CrossRef]

83. Zhao, Y.; Chen, R.; Wang, Y.; Yang, Y. alpha-Pinene Inhibits Human Prostate Cancer Growth in a Mouse Xenograft Model. Chemotherapy 2018, 63, 1-7. [CrossRef] [PubMed]

84. Araujo-Filho, H.G.; Pereira, E.W.M.; Rezende, M.M.; Menezes, P.P.; Araujo, A.A.S.; Barreto, R.S.S.; Martins, A.; Albuquerque, T.R.; Silva, B.A.F.; Alcantara, I.S.; et al. D-limonene exhibits superior antihyperalgesic effects in a beta-cyclodextrin-complexed form in chronic musculoskeletal pain reducing Fos protein expression on spinal cord in mice. Neuroscience 2017, 358, 158-169. [CrossRef] [PubMed]

85. Booth, J.K.; Page, J.E.; Bohlmann, J. Terpene synthases from Cannabis sativa. PLoS ONE 2017, $12, \mathrm{e} 0173911$. [CrossRef] [PubMed]

86. Naz, S.; Hanif, M.A.; Ansari, T.M.; Al-Sabahi, J.N. A Comparative Study on Hemp (Cannabis sativa) Essential Oil Extraction Using Traditional and Advanced Techniques. Guang Pu Xue Yu Guang Pu Fen Xi=Guang Pu 2017, 37, 306-311.

87. Fidyt, K.; Fiedorowicz, A.; Strzadala, L.; Szumny, A. beta-caryophyllene and beta-caryophyllene oxide-natural compounds of anticancer and analgesic properties. Cancer Med. 2016, 5, 3007-3017. [CrossRef]

88. Sabulal, B.; Dan, M.; J, A.J.; Kurup, R.; Pradeep, N.S.; Valsamma, R.K.; George, V. Caryophyllene-rich rhizome oil of Zingiber nimmonii from South India: Chemical characterization and antimicrobial activity. Phytochemistry 2006, 67, 2469-2473. [CrossRef]

89. Su, Y.C.; Ho, C.L. Composition of the Leaf Essential Oil of Phoebe formosana from Taiwan and its in vitro Cytotoxic, Antibacterial, and Antifungal Activities. Nat. Prod. Commun. 2016, 11, 845-848. [CrossRef]

90. Sarvmeili, N.; Jafarian-Dehkordi, A.; Zolfaghari, B. Cytotoxic effects of Pinus eldarica essential oil and extracts on HeLa and MCF-7 cell lines. Res. Pharm. Sci. 2016, 11, 476-483.

91. Memariani, T.; Hosseini, T.; Kamali, H.; Mohammadi, A.; Ghorbani, M.; Shakeri, A.; Spandidos, D.A.; Tsatsakis, A.M.; Shahsavand, S. Evaluation of the cytotoxic effects of Cyperus longus extract, fractions and its essential oil on the PC3 and MCF7 cancer cell lines. Oncol. Lett. 2016, 11, 1353-1360. [CrossRef]

92. Segat, G.C.; Manjavachi, M.N.; Matias, D.O.; Passos, G.F.; Freitas, C.S.; Costa, R.; Calixto, J.B. Antiallodynic effect of beta-caryophyllene on paclitaxel-induced peripheral neuropathy in mice. Neuropharmacology 2017, 125, 207-219. [CrossRef]

93. Bento, A.F.; Marcon, R.; Dutra, R.C.; Claudino, R.F.; Cola, M.; Leite, D.F.; Calixto, J.B. beta-Caryophyllene inhibits dextran sulfate sodium-induced colitis in mice through CB2 receptor activation and PPARgamma pathway. Am. J. Pathol. 2011, 178, 1153-1166. [CrossRef] [PubMed]

94. Gertsch, J.; Leonti, M.; Raduner, S.; Racz, I.; Chen, J.Z.; Xie, X.Q.; Altmann, K.H.; Karsak, M.; Zimmer, A. Beta-caryophyllene is a dietary cannabinoid. Proc. Natl. Acad. Sci. USA 2008, 105, 9099-9104. [CrossRef] [PubMed] 
95. Alberti, T.B.; Marcon, R.; Bicca, M.A.; Raposo, N.R.; Calixto, J.B.; Dutra, R.C. Essential oil from Pterodon emarginatus seeds ameliorates experimental autoimmune encephalomyelitis by modulating Th1/Treg cell balance. J. Ethnopharmacol. 2014, 155, 485-494. [CrossRef]

96. Alberti, T.B.; Barbosa, W.L.; Vieira, J.L.; Raposo, N.R.; Dutra, R.C. (-)-beta-Caryophyllene, a CB2 Receptor-Selective Phytocannabinoid, Suppresses Motor Paralysis and Neuroinflammation in a Murine Model of Multiple Sclerosis. Int. J. Mol. Sci. 2017, 18, 691. [CrossRef] [PubMed]

97. Fernandes, E.S.; Passos, G.F.; Medeiros, R.; da Cunha, F.M.; Ferreira, J.; Campos, M.M.; Pianowski, L.F.; Calixto, J.B. Anti-inflammatory effects of compounds alpha-humulene and (-)-trans-caryophyllene isolated from the essential oil of Cordia verbenacea. Eur. J. Pharmacol. 2007, 569, 228-236. [CrossRef]

98. Ojha, S.; Javed, H.; Azimullah, S.; Haque, M.E. beta-Caryophyllene, a phytocannabinoid attenuates oxidative stress, neuroinflammation, glial activation, and salvages dopaminergic neurons in a rat model of Parkinson disease. Mol. Cell. Biochem. 2016, 418, 59-70. [CrossRef]

99. Sut, S.; Maggi, F.; Nicoletti, M.; Baldan, V.; Dall Acqua, S. New Drugs from Old Natural Compounds: Scarcely Investigated Sesquiterpenes as New Possible Therapeutic Agents. Curr. Med. Chem. 2018, 25, 1241-1258. [CrossRef]

100. Santiago, M.; Sachdev, S.; Arnold, J.C.; McGregor, I.S.; Connor, M. Absence of Entourage: Terpenoids Commonly Found in Cannabis sativa Do Not Modulate the Functional Activity of Delta(9)-THC at Human CB1 and CB2 Receptors. Cannabis Cannabinoid Res. 2019, 4, 165-176. [CrossRef]

101. Sun, J. D-Limonene: Safety and clinical applications. Altern. Med. Rev. J. Clin. Ther. 2007, 12, $259-264$.

102. Shah, B.B.; Baksi, R.; Chaudagar, K.K.; Nivsarkar, M.; Mehta, A.A. Anti-leukemic and anti-angiogenic effects of d-Limonene on K562-implanted C57BL/6 mice and the chick chorioallantoic membrane model. Anim. Models Exp. Med. 2018, 1, 328-333. [CrossRef]

103. d'Alessio, P.A.; Ostan, R.; Bisson, J.F.; Schulzke, J.D.; Ursini, M.V.; Bene, M.C. Oral administration of d-limonene controls inflammation in rat colitis and displays anti-inflammatory properties as diet supplementation in humans. Life Sci. 2013, 92, 1151-1156. [CrossRef] [PubMed]

104. Shin, M.; Liu, Q.F.; Choi, B.; Shin, C.; Lee, B.; Yuan, C.; Song, Y.J.; Yun, H.S.; Lee, I.S.; Koo, B.S.; et al. Neuroprotective effects of limonene (+) against Abeta42-induced neurotoxicity in a Drosophila model of Alzheimer's disease. Biol. Pharm. Bull. 2019. [CrossRef]

105. de Almeida, A.A.; Silva, R.O.; Nicolau, L.A.; de Brito, T.V.; de Sousa, D.P.; Barbosa, A.L.; de Freitas, R.M.; Lopes, L.D.; Medeiros, J.R.; Ferreira, P.M. Physio-pharmacological Investigations About the Anti-inflammatory and Antinociceptive Efficacy of (+)-Limonene Epoxide. Inflammation 2017, 40, 511-522. [CrossRef] [PubMed]

106. Rozza, A.L.; Moraes Tde, M.; Kushima, H.; Tanimoto, A.; Marques, M.O.; Bauab, T.M.; Hiruma-Lima, C.A.; Pellizzon, C.H. Gastroprotective mechanisms of Citrus lemon (Rutaceae) essential oil and its majority compounds limonene and beta-pinene: Involvement of heat-shock protein-70, vasoactive intestinal peptide, glutathione, sulfhydryl compounds, nitric oxide and prostaglandin E(2). Chem. Biol. Interact. 2011, 189, 82-89.

107. de Souza, M.C.; Vieira, A.J.; Beserra, F.P.; Pellizzon, C.H.; Nobrega, R.H.; Rozza, A.L. Gastroprotective effect of limonene in rats: Influence on oxidative stress, inflammation and gene expression. Phytomed. Int. J. Phytother. Phytopharm. 2019, 53, 37-42. [CrossRef]

108. Wang, L.; Zhang, Y.; Fan, G.; Ren, J.N.; Zhang, L.L.; Pan, S.Y. Effects of orange essential oil on intestinal microflora in mice. J. Sci. Food Agric. 2019, 99, 4019-4028. [CrossRef]

109. do Amaral, J.F.; Silva, M.I.; Neto, M.R.; Neto, P.F.; Moura, B.A.; de Melo, C.T.; de Araujo, F.L.; de Sousa, D.P.; de Vasconcelos, P.F.; de Vasconcelos, S.M.; et al. Antinociceptive effect of the monoterpene R-(+)-limonene in mice. Biol. Pharm. Bull. 2007, 30, 1217-1220. [CrossRef]

110. Piccinelli, A.C.; Santos, J.A.; Konkiewitz, E.C.; Oesterreich, S.A.; Formagio, A.S.; Croda, J.; Ziff, E.B.; Kassuya, C.A. Antihyperalgesic and antidepressive actions of (R)-(+)-limonene, alpha-phellandrene, and essential oil from Schinus terebinthifolius fruits in a neuropathic pain model. Nutr. Neurosci. 2015, 18, 217-224. [CrossRef]

111. Smeriglio, A.; Alloisio, S.; Raimondo, F.M.; Denaro, M.; Xiao, J.; Cornara, L.; Trombetta, D. Essential oil of Citrus lumia Risso: Phytochemical profile, antioxidant properties and activity on the central nervous system. Food Chem. Toxicol. Int. J. Publ. Br. Ind. Biol. Res. Assoc. 2018, 119, 407-416. [CrossRef] 
112. Zhang, Y.; Wang, J.; Cao, X.; Liu, W.; Yu, H.; Ye, L. High-level production of linalool by engineered Saccharomyces cerevisiae harboring dual mevalonate pathways in mitochondria and cytoplasm. Enzym. Microb. Technol. 2020, 134, 109462. [CrossRef]

113. Kim, M.G.; Kim, S.M.; Min, J.H.; Kwon, O.K.; Park, M.H.; Park, J.W.; Ahn, H.I.; Hwang, J.Y.; Oh, S.R.; Lee, J.W.; et al. Anti-inflammatory effects of linalool on ovalbumin-induced pulmonary inflammation. Int. Immunopharmacol. 2019, 74, 105706. [CrossRef] [PubMed]

114. Sabogal-Guaqueta, A.M.; Hobbie, F.; Keerthi, A.; Oun, A.; Kortholt, A.; Boddeke, E.; Dolga, A. Linalool attenuates oxidative stress and mitochondrial dysfunction mediated by glutamate and NMDA toxicity. Biomed. Pharmacother. 2019, 118, 109295. [CrossRef] [PubMed]

115. Harada, H.; Kashiwadani, H.; Kanmura, Y.; Kuwaki, T. Linalool Odor-Induced Anxiolytic Effects in Mice. Front. Behav. Neurosci. 2018, 12, 241. [CrossRef] [PubMed]

116. Xu, P.; Wang, K.; Lu, C.; Dong, L.; Gao, L.; Yan, M.; Aibai, S.; Yang, Y.; Liu, X. Protective effects of linalool against amyloid beta-induced cognitive deficits and damages in mice. Life Sci. 2017, 174, 21-27. [CrossRef] [PubMed]

117. Iwasaki, K.; Zheng, Y.W.; Murata, S.; Ito, H.; Nakayama, K.; Kurokawa, T.; Sano, N.; Nowatari, T.; Villareal, M.O.; Nagano, Y.N.; et al. Anticancer effect of linalool via cancer-specific hydroxyl radical generation in human colon cancer. World J. Gastroenterol. 2016, 22, 9765-9774. [CrossRef]

118. Gunaseelan, S.; Balupillai, A.; Govindasamy, K.; Muthusamy, G.; Ramasamy, K.; Shanmugam, M.; Prasad, N.R. The preventive effect of linalool on acute and chronic UVB-mediated skin carcinogenesis in Swiss albino mice. Photochem. Photobiol. Sci. Off. J. Eur. Photochem. Assoc. Eur. Soc. Photobiol. 2016, 15, 851-860. [CrossRef]

119. Katsuyama, S.; Kuwahata, H.; Yagi, T.; Kishikawa, Y.; Komatsu, T.; Sakurada, T.; Nakamura, H. Intraplantar injection of linalool reduces paclitaxel-induced acute pain in mice. Biomed. Res. 2012, 33, 175-181. [CrossRef]

120. Ibrahim, E.A.; Wang, M.; Radwan, M.M.; Wanas, A.S.; Majumdar, C.G.; Avula, B.; Wang, Y.H.; Khan, I.A.; Chandra, S.; Lata, H.; et al. Analysis of Terpenes in Cannabis sativa L. Using GC/MS: Method Development, Validation, and Application. Planta Med. 2019, 85, 431-438. [CrossRef]

121. Oliveira, M.G.; Brito, R.G.; Santos, P.L.; Araujo-Filho, H.G.; Quintans, J.S.; Menezes, P.P.; Serafini, M.R.; Carvalho, Y.M.; Silva, J.C.; Almeida, J.R.; et al. alpha-Terpineol, a monoterpene alcohol, complexed with beta-cyclodextrin exerts antihyperalgesic effect in animal model for fibromyalgia aided with docking study. Chem. Biol. Interact. 2016, 254, 54-62. [CrossRef]

122. Kumar Chaudhari, A.; Singh, A.; Kumar Singh, V.; Kumar Dwivedy, A.; Das, S.; Grace Ramsdam, M.; Dkhar, M.S.; Kayang, H.; Kishore Dubey, N. Assessment of chitosan biopolymer encapsulated alpha-Terpineol against fungal, aflatoxin B1 (AFB1) and free radicals mediated deterioration of stored maize and possible mode of action. Food Chem. 2020, 311, 126010. [CrossRef]

123. de Oliveira, M.G.; Marques, R.B.; de Santana, M.F.; Santos, A.B.; Brito, F.A.; Barreto, E.O.; De Sousa, D.P.; Almeida, F.R.; Badaue-Passos, D., Jr.; Antoniolli, A.R.; et al. alpha-terpineol reduces mechanical hypernociception and inflammatory response. Basic Clin. Pharmacol. Toxicol. 2012, 111, 120-125. [PubMed]

124. Dos Santos Negreiros, P.; da Costa, D.S.; da Silva, V.G.; de Carvalho Lima, I.B.; Nunes, D.B.; de Melo Sousa, F.B.; de Souza Lopes Araujo, T.; Medeiros, J.V.R.; Dos Santos, R.F.; de Cassia Meneses Oliveira, R. Antidiarrheal activity of alpha-terpineol in mice. Biomed. Pharmacother. 2019, 110, 631-640. [CrossRef] [PubMed]

125. Gouveia, D.N.; Costa, J.S.; Oliveira, M.A.; Rabelo, T.K.; Silva, A.; Carvalho, A.A.; Miguel-Dos-Santos, R.; Lauton-Santos, S.; Scotti, L.; Scotti, M.T.; et al. alpha-Terpineol reduces cancer pain via modulation of oxidative stress and inhibition of iNOS. Biomed. Pharmacother. 2018, 105, 652-661. [CrossRef] [PubMed]

126. Parvardeh, S.; Moghimi, M.; Eslami, P.; Masoudi, A. alpha-Terpineol attenuates morphine-induced physical dependence and tolerance in mice: Role of nitric oxide. Iran. J. Basic Med Sci. 2016, 19, 201-208. [PubMed]

127. Moghimi, M.; Parvardeh, S.; Zanjani, T.M.; Ghafghazi, S. Protective effect of alpha-terpineol against impairment of hippocampal synaptic plasticity and spatial memory following transient cerebral ischemia in rats. Iran. J. Basic Med Sci. 2016, 19, 960-969. [PubMed]

128. Kim, K.; Bu, Y.; Jeong, S.; Lim, J.; Kwon, Y.; Cha, D.S.; Kim, J.; Jeon, S.; Eun, J.; Jeon, H. Memory-enhancing effect of a supercritical carbon dioxide fluid extract of the needles of Abies koreana on scopolamine-induced amnesia in mice. Biosci. Biotechnol. Biochem. 2006, 70, 1821-1826. [CrossRef] 
129. Nogueira, M.N.; Aquino, S.G.; Rossa Junior, C.; Spolidorio, D.M. Terpinen-4-ol and alpha-terpineol (tea tree oil components) inhibit the production of IL-1beta, IL-6 and IL-10 on human macrophages. Inflamm. Res. 2014, 63, 769-778. [CrossRef]

130. Jing, G.X.; Tao, N.G.; Jia, L.; Zhou, H.E. Influence of alpha-terpineol on the growth and morphogenesis of Penicillium digitatum. Bot. Stud. 2015, 56, 35. [CrossRef]

131. Sharifi-Rad, J.; Salehi, B.; Varoni, E.M.; Sharopov, F.; Yousaf, Z.; Ayatollahi, S.A.; Kobarfard, F.; Sharifi-Rad, M.; Afdjei, M.H.; Sharifi-Rad, M.; et al. Plants of the Melaleuca Genus as Antimicrobial Agents: From Farm to Pharmacy. Phytother. Res. PTR 2017, 31, 1475-1494. [CrossRef]

132. Chen, Y.; Weng, Y.; Zhou, M.; Meng, Y.; Liu, J.; Yang, L.; Zuo, Z. Linalool- and alpha-terpineol-induced programmed cell death in Chlamydomonas reinhardtii. Ecotoxicol. Environ. Saf. 2019, 167, 435-440. [CrossRef]

133. Wua, Y.; Chenb, H.P.; Wei, J.Y.; Yang, K.; Tian, Z.F.; Li, X.L.; Wang, P.J.; Wang, C.F.; Du, S.S.; Cai, Q. Repellent Constituents of essential oil from Citrus wilsonii stem barks against Tribolium castaneum. Nat. Prod. Commun. 2014, 9, 1515-1518. [CrossRef] [PubMed]

134. Villa-Ruano, N.; Becerra-Martinez, E.; Cruz-Duran, R.; Zarate-Reyes, J.A.; Landeta-Cortes, G.; Romero-Arenas, O. Volatile Profiling, Insecticidal, Antibacterial and Antiproliferative Properties of the Essential Oils of Bursera glabrifolia Leaves. Chem. Biodivers. 2018, 15, e1800354. [CrossRef] [PubMed]

135. Hassan, S.B.; Gali-Muhtasib, H.; Goransson, H.; Larsson, R. Alpha terpineol: A potential anticancer agent which acts through suppressing NF-kB signalling. Anticancer Res. 2010, 30, 1911-1919. [PubMed]

136. Djenane, D.; Yanguela, J.; Amrouche, T.; Boubrit, S.; Boussad, N.; Roncales, P. Chemical composition and antimicrobial effects of essential oils of Eucalyptus globulus, Myrtus communis and Satureja hortensis against Escherichia coli O157:H7 and Staphylococcus aureus in minced beef. Food Sci. Technol. Int. = Cienc. Tecnol. Aliment. Int. 2011, 17, 505-515. [CrossRef] [PubMed]

137. Ramalho, T.R.; Pacheco de Oliveira, M.T.; Lima, A.L.; Bezerra-Santos, C.R.; Piuvezam, M.R. Erratum for: Gamma-Terpinene Modulates Acute Inflammatory Response in Mice. Planta Med. 2015, 81, E3. [CrossRef] [PubMed]

138. Su, Y.C.; Hsu, K.P.; Hua, K.F.; Ho, C.L. Composition, in vitro Anti-inflammatory, Antioxidant and Antimicrobial Activities of Essential Oils from Leaf and Twig Parts of Cupressus cashmeriana. Nat. Prod. Commun. 2015, 10, 1461-1464. [CrossRef]

139. Xavier, A.L.; Pita, J.C.; Brito, M.T.; Meireles, D.R.; Tavares, J.F.; Silva, M.S.; Maia, J.G.; Andrade, E.H.; Diniz, M.F.; Silva, T.G.; et al. Chemical composition, antitumor activity, and toxicity of essential oil from the leaves of Lippia microphylla. Z. Fur Naturforschung. Cjournal Biosci. 2015, 70, 129-137. [CrossRef]

140. Mekonnen, A.; Tesfaye, S.; Christos, S.G.; Dires, K.; Zenebe, T.; Zegeye, N.; Shiferaw, Y.; Lulekal, E. Evaluation of Skin Irritation and Acute and Subacute Oral Toxicity of Lavandula angustifolia Essential Oils in Rabbit and Mice. J. Toxicol. 2019, 2019, 5979546. [CrossRef]

141. Plastina, P.; Apriantini, A.; Meijerink, J.; Witkamp, R.; Gabriele, B.; Fazio, A. In Vitro Anti-Inflammatory and Radical Scavenging Properties of Chinotto (Citrus myrtifolia Raf.) Essential Oils. Nutrients 2018, 10, 783. [CrossRef]

142. Lima Mda, S.; Quintans-Junior, L.J.; de Santana, W.A.; Martins Kaneto, C.; Pereira Soares, M.B.; Villarreal, C.F. Anti-inflammatory effects of carvacrol: Evidence for a key role of interleukin-10. Eur. J. Pharmacol. 2013, 699, 112-117. [CrossRef]

143. Guimaraes, A.G.; Quintans, J.S.; Quintans, L.J., Jr. Monoterpenes with analgesic activity-a systematic review. Phytother. Res. PTR 2013, 27, 1-15. [CrossRef]

144. Siveen, K.S.; Kuttan, G. Thujone inhibits lung metastasis induced by B16F-10 melanoma cells in C57BL/6 mice. Can. J. Physiol. Pharmacol. 2011, 89, 691-703. [CrossRef] [PubMed]

145. Ramalho, T.R.; Pacheco de Oliveira, M.T.; Lima, A.L.; Bezerra-Santos, C.R.; Piuvezam, M.R. Gamma-Terpinene Modulates Acute Inflammatory Response in Mice. Planta Med. 2015, 81, 1248-1254. [CrossRef] [PubMed]

146. Ramalho, T.R.; Filgueiras, L.R.; Pacheco de Oliveira, M.T.; Lima, A.L.; Bezerra-Santos, C.R.; Jancar, S.; Piuvezam, M.R. Gamma-Terpinene Modulation of LPS-Stimulated Macrophages is Dependent on the PGE2/IL-10 Axis. Planta Med. 2016, 82, 1341-1345. [CrossRef] [PubMed]

147. Baldissera, M.D.; Grando, T.H.; Souza, C.F.; Gressler, L.T.; Stefani, L.M.; da Silva, A.S.; Monteiro, S.G. In vitro and in vivo action of terpinen-4-ol, gamma-terpinene, and alpha-terpinene against Trypanosoma evansi. Exp. Parasitol. 2016, 162, 43-48. [CrossRef] [PubMed] 
148. Assmann, C.E.; Cadona, F.C.; Bonadiman, B.; Dornelles, E.B.; Trevisan, G.; Cruz, I. Tea tree oil presents in vitro antitumor activity on breast cancer cells without cytotoxic effects on fibroblasts and on peripheral blood mononuclear cells. Biomed. Pharmacother. 2018, 103, 1253-1261. [CrossRef]

149. Begum, A.; Sandhya, S.; Shaffath Ali, S.; Vinod, K.R.; Reddy, S.; Banji, D. An in-depth review on the medicinal flora Rosmarinus officinalis (Lamiaceae). Acta Sci. Polonorum. Technol. Aliment. 2013, 12, 61-73.

150. Nissen, L.; Zatta, A.; Stefanini, I.; Grandi, S.; Sgorbati, B.; Biavati, B.; Monti, A. Characterization and antimicrobial activity of essential oils of industrial hemp varieties (Cannabis sativa L.). Fitoterapia 2010, 81, 413-419. [CrossRef]

151. Yang, H.; Woo, J.; Pae, A.N.; Um, M.Y.; Cho, N.C.; Park, K.D.; Yoon, M.; Kim, J.; Lee, C.J.; Cho, S. alpha-Pinene, a Major Constituent of Pine Tree Oils, Enhances Non-Rapid Eye Movement Sleep in Mice through GABAA-benzodiazepine Receptors. Mol. Pharmacol. 2016, 90, 530-539. [CrossRef]

152. Satou, T.; Kasuya, H.; Maeda, K.; Koike, K. Daily inhalation of alpha-pinene in mice: Effects on behavior and organ accumulation. Phytother. Res. PTR 2014, 28, 1284-1287. [CrossRef]

153. Mercier, B.; Prost, J.; Prost, M. The essential oil of turpentine and its major volatile fraction (alpha- and beta-pinenes): A review. Int. J. Occup. Med. Environ. Health 2009, 22, 331-342. [CrossRef] [PubMed]

154. Nuutinen, T. Medicinal properties of terpenes found in Cannabis sativa and Humulus lupulus. Eur. J. Med. Chem. 2018, 157, 198-228. [CrossRef] [PubMed]

155. Kasuya, H.; Iida, S.; Ono, K.; Satou, T.; Koike, K. Intracerebral Distribution of a-Pinene and the Anxiolytic-like Effect in Mice Following Inhaled Administration of Essential Oil from Chamaecyparis obtuse. Nat. Prod. Commun. 2015, 10, 1479-1482. [CrossRef] [PubMed]

156. Ueno, H.; Shimada, A.; Suemitsu, S.; Murakami, S.; Kitamura, N.; Wani, K.; Matsumoto, Y.; Okamoto, M.; Ishihara, T. Attenuation Effects of Alpha-Pinene Inhalation on Mice with Dizocilpine-Induced Psychiatric-Like Behaviour. Evid. Based Complement. Altern. Med. ECAM 2019, 2019, 2745453. [CrossRef]

157. Lee, G.Y.; Lee, C.; Park, G.H.; Jang, J.H. Amelioration of Scopolamine-Induced Learning and Memory Impairment by alpha-Pinene in C57BL/6 Mice. Evid. Based Complement. Altern. Med. Ecam 2017, 2017, 4926815. [CrossRef]

158. Karthikeyan, R.; Kanimozhi, G.; Prasad, N.R.; Agilan, B.; Ganesan, M.; Srithar, G. Alpha pinene modulates UVA-induced oxidative stress, DNA damage and apoptosis in human skin epidermal keratinocytes. Life Sci. 2018, 212, 150-158. [CrossRef]

159. Karthikeyan, R.; Kanimozhi, G.; Madahavan, N.R.; Agilan, B.; Ganesan, M.; Prasad, N.R.; Rathinaraj, P. Alpha-pinene attenuates UVA-induced photoaging through inhibition of matrix metalloproteinases expression in mouse skin. Life Sci. 2019, 217, 110-118. [CrossRef]

160. Bouzenna, H.; Hfaiedh, N.; Giroux-Metges, M.A.; Elfeki, A.; Talarmin, H. Potential protective effects of alpha-pinene against cytotoxicity caused by aspirin in the IEC-6 cells. Biomed. Pharmacother. 2017, 93, 961-968. [CrossRef]

161. Hou, J.; Zhang, Y.; Zhu, Y.; Zhou, B.; Ren, C.; Liang, S.; Guo, Y. alpha-Pinene Induces Apoptotic Cell Death via Caspase Activation in Human Ovarian Cancer Cells. Med Sci. Monit.: Int. Med J. Exp. Clin. Res. 2019, 25, 6631-6638. [CrossRef]

162. Xu, Q.; Li, M.; Yang, M.; Yang, J.; Xie, J.; Lu, X.; Wang, F.; Chen, W. alpha-pinene regulates miR-221 and induces G2/M phase cell cycle arrest in human hepatocellular carcinoma cells. Biosci. Rep. 2018, 38. [CrossRef]

163. Rahbar, I.; Abbasnejad, M.; Haghani, J.; Raoof, M.; Kooshki, R.; Esmaeili-Mahani, S. The effect of central administration of alpha-pinene on capsaicin-induced dental pulp nociception. Int. Endod. J. 2019, 52, 307-317. [CrossRef] [PubMed]

164. Li, X.J.; Yang, Y.J.; Li, Y.S.; Zhang, W.K.; Tang, H.B. alpha-Pinene, linalool, and 1-octanol contribute to the topical anti-inflammatory and analgesic activities of frankincense by inhibiting COX-2. J. Ethnopharmacol. 2016, 179, 22-26. [CrossRef] [PubMed]

165. Iseppi, R.; Brighenti, V.; Licata, M.; Lambertini, A.; Sabia, C.; Messi, P.; Pellati, F.; Benvenuti, S. Chemical Characterization and Evaluation of the Antibacterial Activity of Essential Oils from Fibre-Type Cannabis sativa L. (Hemp). Molecules 2019, 24, 2302. [CrossRef] [PubMed]

166. Pertwee, R.G.E. Handbook of Cannabis, 1st ed.; Oxford University Press: London, UK, 2016.

167. Mahajan, P.; Singh, H.P.; Kaur, S.; Batish, D.R.; Kohli, R.K. beta-Pinene moderates Cr(VI) phytotoxicity by quenching reactive oxygen species and altering antioxidant machinery in maize. Environ. Sci. Pollut. Res. Int. 2019, 26, 456-463. [CrossRef] [PubMed] 
168. Pajaro-Castro, N.; Caballero-Gallardo, K.; Olivero-Verbel, J. Neurotoxic Effects of Linalool and beta-Pinene on Tribolium castaneum Herbst. Molecules 2017, 22, 2052. [CrossRef]

169. Guzman-Gutierrez, S.L.; Gomez-Cansino, R.; Garcia-Zebadua, J.C.; Jimenez-Perez, N.C.; Reyes-Chilpa, R. Antidepressant activity of Litsea glaucescens essential oil: Identification of beta-pinene and linalool as active principles. J. Ethnopharmacol. 2012, 143, 673-679. [CrossRef]

170. Guzman-Gutierrez, S.L.; Bonilla-Jaime, H.; Gomez-Cansino, R.; Reyes-Chilpa, R. Linalool and beta-pinene exert their antidepressant-like activity through the monoaminergic pathway. Life Sci. 2015, 128, 24-29. [CrossRef]

171. Wang, Y.; Wu, C.; Zhang, Q.; Shan, Y.; Gu, W.; Wang, S. Design, synthesis and biological evaluation of novel beta-pinene-based thiazole derivatives as potential anticancer agents via mitochondrial-mediated apoptosis pathway. Bioorg. Chem. 2019, 84, 468-477. [CrossRef]

172. Astani, A.; Reichling, J.; Schnitzler, P. Comparative study on the antiviral activity of selected monoterpenes derived from essential oils. Phytother. Res. PTR 2010, 24, 673-679. [CrossRef]

173. Zhou, L.; Zhang, Z.; Wei, M.; Xie, Y.; He, S.; Shi, H.; Lin, Z. Evaluation of the antifungal activity of individual and combined monoterpenes against Rhizopus stolonifer and Absidia coerulea. Environ. Sci. Pollut. Res. Int. 2019, 26, 7804-7809. [CrossRef]

174. Astani, A.; Schnitzler, P. Antiviral activity of monoterpenes beta-pinene and limonene against herpes simplex virus in vitro. Iran. J. Microbiol. 2014, 6, 149-155. [PubMed]

175. de Macedo Andrade, A.C.; Rosalen, P.L.; Freires, I.A.; Scotti, L.; Scotti, M.T.; Aquino, S.G.; de Castro, R.D. Antifungal Activity, Mode of Action, Docking Prediction and Anti-biofilm Effects of (+)-beta-pinene Enantiomers against Candida spp. Curr. Top. Med. Chem. 2018, 18, 2481-2490. [CrossRef] [PubMed]

176. Jia, N.; Arthington-Skaggs, B.; Lee, W.; Pierson, C.A.; Lees, N.D.; Eckstein, J.; Barbuch, R.; Bard, M. Candida albicans sterol C-14 reductase, encoded by the ERG24 gene, as a potential antifungal target site. Antimicrob. Agents Chemother. 2002, 46, 947-957. [CrossRef] [PubMed]

177. Rivas da Silva, A.C.; Lopes, P.M.; Barros de Azevedo, M.M.; Costa, D.C.; Alviano, C.S.; Alviano, D.S. Biological activities of alpha-pinene and beta-pinene enantiomers. Molecules 2012, 17, 6305-6316. [CrossRef] [PubMed]

178. Marchini, M.; Charvoz, C.; Dujourdy, L.; Baldovini, N.; Filippi, J.J. Multidimensional analysis of cannabis volatile constituents: Identification of 5,5-dimethyl-1-vinylbicyclo[2.1.1]hexane as a volatile marker of hashish, the resin of Cannabis sativa L. J. Chromatography. A 2014, 1370, 200-215. [CrossRef] [PubMed]

179. Booth, J.K.; Bohlmann, J. Terpenes in Cannabis sativa-From plant genome to humans. Plant Sci. Int. J. Exp. Plant Biol. 2019, 284, 67-72. [CrossRef] [PubMed]

180. Zhai, B.; Zhang, N.; Han, X.; Li, Q.; Zhang, M.; Chen, X.; Li, G.; Zhang, R.; Chen, P.; Wang, W.; et al. Molecular targets of beta-elemene, a herbal extract used in traditional Chinese medicine, and its potential role in cancer therapy: A review. Biomed. Pharmacother. 2019, 114, 108812. [CrossRef]

181. Deng, M.; Zhang, Y.; Liu, B.; Chen, Y.; Song, H.; Yu, R.; Che, X.; Qu, X.; Liu, Y.; Hu, X.; et al. beta-Elemene inhibits peritoneal metastasis of gastric cancer cells by modulating FAK/Claudin-1 signaling. Phytother. Res. PTR 2019, 33, 2448-2456. [CrossRef]

182. Wu, Z.; Wang, T.; Zhang, Y.; Zheng, Z.; Yu, S.; Jing, S.; Chen, S.; Jiang, H.; Ma, S. Anticancer effects of beta-elemene with hyperthermia in lung cancer cells. Exp. Ther. Med. 2017, 13, 3153-3157. [CrossRef]

183. Fang, M.; Mei, X.; Yao, H.; Zhang, T.; Zhang, T.; Lu, N.; Liu, Y.; Xu, W.; Wan, C. beta-elemene enhances anticancer and anti-metastatic effects of osteosarcoma of ligustrazine in vitro and in vivo. Oncol. Lett. 2018, 15, 3957-3964.

184. Cai, B.; Ma, L.; Nong, S.; Wu, Y.; Guo, X.; Pu, J. beta-elemene induced anticancer effect in bladder cancer through upregulation of PTEN and suppression of AKT phosphorylation. Oncol. Lett. 2018, 16, 6019-6025. [PubMed]

185. Liu, J.S.; He, S.C.; Zhang, Z.L.; Chen, R.; Fan, L.; Qiu, G.L.; Chang, S.; Li, L.; Che, X.M. Anticancer effects of beta-elemene in gastric cancer cells and its potential underlying proteins: A proteomic study. Oncol. Rep. 2014, 32, 2635-2647. [CrossRef] [PubMed]

186. Li, Q.Q.; Lee, R.X.; Liang, H.; Zhong, Y. Anticancer activity of beta-Elemene and its synthetic analogs in human malignant brain tumor cells. Anticancer Res. 2013, 33, 65-76. [PubMed]

187. Wei, Y.; Pu, X.; Zhao, L. Preclinical studies for the combination of paclitaxel and curcumin in cancer therapy. Oncol. Rep. 2017, 37, 3159-3166. [CrossRef] [PubMed] 
188. Li, X.; Gao, C.; Wu, Y.; Cheng, C.Y.; Xia, W.; Zhang, Z. Combination delivery of Adjudin and Doxorubicin via integrating drug conjugation and nanocarrier approaches for the treatment of drug-resistant cancer cells. J. Mater. Chem. B 2015, 3, 1556-1564. [CrossRef] [PubMed]

189. Yao, Y.Q.; Ding, X.; Jia, Y.C.; Huang, C.X.; Wang, Y.Z.; Xu, Y.H. Anti-tumor effect of beta-elemene in glioblastoma cells depends on p38 MAPK activation. Cancer Lett. 2008, 264, 127-134. [CrossRef]

190. Jiang, Z.; Jacob, J.A.; Loganathachetti, D.S.; Nainangu, P.; Chen, B. beta-Elemene: Mechanistic Studies on Cancer Cell Interaction and Its Chemosensitization Effect. Front. Pharmacol. 2017, 8, 105. [CrossRef]

191. Li, Q.Q.; Wang, G.; Zhang, M.; Cuff, C.F.; Huang, L.; Reed, E. beta-Elemene, a novel plant-derived antineoplastic agent, increases cisplatin chemosensitivity of lung tumor cells by triggering apoptosis. Oncol. Rep. 2009, 22, 161-170. [CrossRef]

192. Eloy, J.O.; Claro de Souza, M.; Petrilli, R.; Barcellos, J.P.; Lee, R.J.; Marchetti, J.M. Liposomes as carriers of hydrophilic small molecule drugs: Strategies to enhance encapsulation and delivery. Colloids Surf. Biointerfaces 2014, 123, 345-363. [CrossRef]

193. Cao, M.; Long, M.; Chen, Q.; Lu, Y.; Luo, Q.; Zhao, Y.; Lu, A.; Ge, C.; Zhu, L.; Chen, Z. Development of beta-elemene and Cisplatin Co-Loaded Liposomes for Effective Lung Cancer Therapy and Evaluation in Patient-Derived Tumor Xenografts. Pharm. Res. 2019, 36, 121. [CrossRef]

194. Cao, C.; Wang, Q.; Liu, Y. Lung cancer combination therapy: Doxorubicin and beta-elemene co-loaded, pH-sensitive nanostructured lipid carriers. Drug Des. Dev. Ther. 2019, 13, 1087-1098. [CrossRef] [PubMed]

195. Zeng, Y.Y.; Zeng, Y.J.; Zhang, N.N.; Li, C.X.; Xie, T.; Zeng, Z.W. The Preparation, Determination of a Flexible Complex Liposome Co-Loaded with Cabazitaxel and beta-Elemene, and Animal Pharmacodynamics on Paclitaxel-Resistant Lung Adenocarcinoma. Molecules 2019, 24, 1697. [CrossRef] [PubMed]

196. Yoshida, T.; Hashimura, M.; Mastumoto, T.; Tazo, Y.; Inoue, H.; Kuwata, T.; Saegusa, M. Transcriptional upregulation of HIF-1alpha by NF-kB/p65 and its associations with beta-catenin/p300 complexes in endometrial carcinoma cells. Lab. Investig. J. Tech. Methods Pathol. 2013, 93, 1184-1193. [CrossRef] [PubMed]

197. Yu, X.; Li, Z.; Zhang, Y.; Xu, M.; Che, Y.; Tian, X.; Wang, R.; Zou, K.; Zou, L. beta-elemene inhibits radiation and hypoxia-induced macrophages infiltration via Prx-1/NF-kB/HIF-1alpha signaling pathway. Oncotargets Ther. 2019, 12, 4203-4211. [CrossRef] [PubMed]

198. Liu, M.; Chen, X.; Ma, J.; Hassan, W.; Wu, H.; Ling, J.; Shang, J. beta-Elemene attenuates atherosclerosis in apolipoprotein E-deficient mice via restoring $\mathrm{NO}$ levels and alleviating oxidative stress. Biomed. Pharmacother. 2017, 95, 1789-1798. [CrossRef] [PubMed]

199. Zhou, Y.; Liu, Y.; Chen, J.; Sun, Y.Z.; Li, L.H.; Chen, L. Inhibition of beta-elemene on the expressions of HIF-lalpha, VEGF and iNOS in diabetic rats model. Int. J. Ophthalmol. 2019, 12, 1693-1698. [CrossRef]

200. Zhang, R.; Tian, A.; Shi, X.; Yu, H.; Chen, L. Downregulation of IL-17 and IFN-gamma in the optic nerve by beta-elemene in experimental autoimmune encephalomyelitis. Int. Immunopharmacol. 2010, 10, 738-743. [CrossRef]

201. Farre-Armengol, G.; Filella, I.; Llusia, J.; Penuelas, J. beta-Ocimene, a Key Floral and Foliar Volatile Involved in Multiple Interactions between Plants and Other Organisms. Molecules 2017, 22, 1148. [CrossRef]

202. Pavlovic, R.; Panseri, S.; Giupponi, L.; Leoni, V.; Citti, C.; Cattaneo, C.; Cavaletto, M.; Giorgi, A. Phytochemical and Ecological Analysis of Two Varieties of Hemp (Cannabis sativa L.) Grown in a Mountain Environment of Italian Alps. Front. Plant Sci. 2019, 10, 1265. [CrossRef]

203. Bomfim, L.M.; Menezes, L.R.; Rodrigues, A.C.; Dias, R.B.; Rocha, C.A.; Soares, M.B.; Neto, A.F.; Nascimento, M.P.; Campos, A.F.; Silva, L.C.; et al. Antitumour Activity of the Microencapsulation of Annona vepretorum Essential Oil. Basic Clin. Pharmacol. Toxicol. 2016, 118, 208-213. [CrossRef]

204. Sayyah, M.; Nadjafnia, L.; Kamalinejad, M. Anticonvulsant activity and chemical composition of Artemisia dracunculus L. essential oil. J. Ethnopharmacol. 2004, 94, 283-287. [CrossRef]

205. Bas \er, K.H.C.; Buchbauer, G. Handbook of Essential Oils: Science, Technology, and Applications; CRC Press/Taylor \& Francis: Boca Raton, FL, USA, 2010.

206. Feng, Y.X.; Wang, Y.; Chen, Z.Y.; Guo, S.S.; You, C.X.; Du, S.S. Efficacy of bornyl acetate and camphene from Valeriana officinalis essential oil against two storage insects. Environ. Sci. Pollut. Res. Int. 2019, 26, 16157-16165. [CrossRef] [PubMed] 
207. Benelli, G.; Govindarajan, M.; Rajeswary, M.; Vaseeharan, B.; Alyahya, S.A.; Alharbi, N.S.; Kadaikunnan, S.; Khaled, J.M.; Maggi, F. Insecticidal activity of camphene, zerumbone and alpha-humulene from Cheilocostus speciosus rhizome essential oil against the Old-World bollworm, Helicoverpa armigera. Ecotoxicol. Environ. Saf. 2018, 148, 781-786. [CrossRef] [PubMed]

208. Benelli, G.; Govindarajan, M.; AlSalhi, M.S.; Devanesan, S.; Maggi, F. High toxicity of camphene and gamma-elemene from Wedelia prostrata essential oil against larvae of Spodoptera litura (Lepidoptera: Noctuidae). Environ. Sci. Pollut. Res. Int. 2018, 25, 10383-10391. [CrossRef] [PubMed]

209. Souza, M.R.P.; Coelho, N.P.; Baldin, V.P.; Scodro, R.B.L.; Cardoso, R.F.; da Silva, C.C.; Vandresen, F. Synthesis of novel (-)-Camphene-based thiosemicarbazones and evaluation of anti-Mycobacterium tuberculosis activity. Nat. Prod. Res. 2019, 33, 3372-3377. [CrossRef] [PubMed]

210. Baldissera, M.D.; Souza, C.F.; Rieffel, R.C.; Velho, M.C.; Ramos, A.P.; Nascimento, K.; Sagrillo, M.R.; Ourique, A.F.; da Silva, A.S.; Stefani, L.M.; et al. Protective effect of nerolidol-loaded in nanospheres against cerebral damage caused by Trypanosoma evansi. Naunyn-Schmiedeberg's Arch. Pharmacol. 2018, 391, 753-759. [CrossRef]

211. Ceole, L.F.; Cardoso, M.D.G.; Soares, M.J. Nerolidol, the main constituent of Piper aduncum essential oil, has anti-Leishmania braziliensis activity. Parasitology 2017, 144, 1179-1190. [CrossRef]

212. Alonso, L.; Fernandes, K.S.; Mendanha, S.A.; Goncalves, P.J.; Gomes, R.S.; Dorta, M.L.; Alonso, A. In vitro antileishmanial and cytotoxic activities of nerolidol are associated with changes in plasma membrane dynamics. Biochim. Biophys. Acta Biomembr. 2019, 1861, 1049-1056. [CrossRef]

213. Silva, M.P.; de Oliveira, R.N.; Mengarda, A.C.; Roquini, D.B.; Allegretti, S.M.; Salvadori, M.C.; Teixeira, F.S.; de Sousa, D.P.; Pinto, P.L.S.; da Silva Filho, A.A.; et al. Antiparasitic activity of nerolidol in a mouse model of schistosomiasis. Int. J. Antimicrob. Agents 2017, 50, 467-472. [CrossRef]

214. Zhang, L.; Sun, D.; Bao, Y.; Shi, Y.; Cui, Y.; Guo, M. Nerolidol Protects Against LPS-induced Acute Kidney Injury via Inhibiting TLR4/NF-kB Signaling. Phytother. Res. PTR 2017, 31, 459-465. [CrossRef]

215. Barros Silva Soares de Souza, E.P.; Trindade, G.; Lins Dantas Gomes, M.V.; Santos Silva, L.A.; Grespan, R.; Quintans Junior, L.J.; Cavalcanti de Albuquerque Junior, R.L.; Shanmugan, S.; Antunes de Souza Araujo, A. Anti-inflammatory effect of nano-encapsulated nerolidol on zymosan-induced arthritis in mice. Food Chem. Toxicol. Int. J. Publ. Br. Ind. Biol. Res. Assoc. 2019, 110958. [CrossRef] [PubMed]

216. Hanusova, V.; Caltova, K.; Svobodova, H.; Ambroz, M.; Skarka, A.; Murinova, N.; Kralova, V.; Tomsik, P.; Skalova, L. The effects of beta-caryophyllene oxide and trans-nerolidol on the efficacy of doxorubicin in breast cancer cells and breast tumor-bearing mice. Biomed. Pharmacother. 2017, 95, 828-836. [CrossRef] [PubMed]

217. Iqubal, A.; Sharma, S.; Najmi, A.K.; Syed, M.A.; Ali, J.; Alam, M.M.; Haque, S.E. Nerolidol ameliorates cyclophosphamide-induced oxidative stress, neuroinflammation and cognitive dysfunction: Plausible role of Nrf2 and NF-kB. Life Sci. 2019, 236, 116867. [CrossRef] [PubMed]

218. Iqubal, A.; Sharma, S.; Ansari, M.A.; Najmi, A.K.; Syed, M.A.; Ali, J.; Alam, M.M.; Ahmad, S.; Haque, S.E. Nerolidol attenuates cyclophosphamide-induced cardiac inflammation, apoptosis and fibrosis in Swiss Albino mice. Eur. J. Pharmacol. 2019, 863, 172666. [CrossRef]

219. Asaikumar, L.; Vennila, L.; Akila, P.; Sivasangari, S.; Kanimozhi, K.; Premalatha, V.; Sindhu, G. Preventive effect of nerolidol on isoproterenol induced myocardial damage in Wistar rats: Evidences from biochemical and histopathological studies. Drug Dev. Res. 2019, 80, 814-823. [CrossRef]

220. Pellati, F.; Borgonetti, V.; Brighenti, V.; Biagi, M.; Benvenuti, S.; Corsi, L. Cannabis sativa L. and Nonpsychoactive Cannabinoids: Their Chemistry and Role against Oxidative Stress, Inflammation, and Cancer. Biomed Res. Int. 2018, 2018, 1691428. [CrossRef]

221. Betancur-Galvis, L.A.; Morales, G.E.; Forero, J.E.; Roldan, J. Cytotoxic and antiviral activities of Colombian medicinal plant extracts of the Euphorbia genus. Mem. Inst. Oswaldo Cruz 2002, 97, 541-546. [CrossRef]

222. Nes, W.D.; Wong, R.Y.; Benson, M.; Landrey, J.R.; Nes, W.R. Rotational isomerism about the 17(20)-bond of steroids and euphoids as shown by the crystal structures of euphol and tirucallol. Proc. Natl. Acad. Sci. USA 1984, 81, 5896-5900. [CrossRef]

223. Xie, X.; Li, Y.; Gao, D.; Zhang, Y.; Ren, Y. Quantitative determination of euphol in rat plasma by LC-MS/MS and its application to a pharmacokinetic study. Biomed. Chromatogr. BMC 2014, 28, 1229-1234. [CrossRef] 
224. de Souza, L.S.; Puziol, L.C.; Tosta, C.L.; Bittencourt, M.L.F.; Ardisson, J.S.; Kitagawa, R.R.; Filgueiras, P.R.; Kuster, R.M. Analytical methods to access the chemical composition of an Euphorbia tirucalli anticancer latex from traditional Brazilian medicine. J. Ethnopharmacol. 2019, 237, 255-265. [CrossRef]

225. Prinsloo, G.; Marokane, C.K.; Street, R.A. Anti-HIV activity of southern African plants: Current developments, phytochemistry and future research. J. Ethnopharmacol. 2018, 210, 133-155. [CrossRef] [PubMed]

226. Mazoir, N.; Benharref, A.; Bailen, M.; Reina, M.; Gonzalez-Coloma, A.; Martinez-Diaz, R.A. Antileishmanial and antitrypanosomal activity of triterpene derivatives from latex of two Euphorbia species. Z. Fur Naturforschung. Cjournal Biosci. 2011, 66, 360-366. [CrossRef] [PubMed]

227. Ibrahim, E.H.; Kilany, M.; Mostafa, O.M.S.; Shaker, K.H.; Alshehri, M.; Alsyaad, K.M.; Alshehri, A.; Khan, K.A.; Qasim, M.; Kotb, N.; et al. TH1/TH2 chemokines/cytokines profile in rats treated with tetanus toxoid and Euphorbia tirucalli. Saudi J. Biol. Sci. 2019, 26, 1716-1723. [CrossRef] [PubMed]

228. Silva, V.A.O.; Rosa, M.N.; Tansini, A.; Oliveira, R.J.S.; Martinho, O.; Lima, J.P.; Pianowski, L.F.; Reis, R.M. In vitro screening of cytotoxic activity of euphol from Euphorbia tirucalli on a large panel of human cancer-derived cell lines. Exp. Ther. Med. 2018, 16, 557-566. [CrossRef]

229. Cruz, L.S.; de Oliveira, T.L.; Kanunfre, C.C.; Paludo, K.S.; Minozzo, B.R.; Prestes, A.P.; Wang, M.; Fernandes, D.; Santos, F.A.D.; Manda, V.K.; et al. Pharmacokinetics and cytotoxic study of euphol from Euphorbia umbellata (Bruyns) Pax latex. Phytomedicine: Int. J. Phytother. Phytopharm. 2018, 47, 105-112. [CrossRef]

230. Wang, L.; Wang, G.; Yang, D.; Guo, X.; Xu, Y.; Feng, B.; Kang, J. Euphol arrests breast cancer cells at the G1 phase through the modulation of cyclin D1, p21 and p27 expression. Mol. Med. Rep. 2013, 8, 1279-1285. [CrossRef]

231. Silva, V.A.O.; Rosa, M.N.; Miranda-Goncalves, V.; Costa, A.M.; Tansini, A.; Evangelista, A.F.; Martinho, O.; Carloni, A.C.; Jones, C.; Lima, J.P.; et al. Euphol, a tetracyclic triterpene, from Euphorbia tirucalli induces autophagy and sensitizes temozolomide cytotoxicity on glioblastoma cells. Investig. New Drugs 2019, 37, 223-237. [CrossRef]

232. Athmouni, K.; El Feki, A.; Ayadi, H. Hepatotoxic effects of Euphol-rich fractions from Euphorbia bivonae-Relevance to cytotoxic and anti-tumor activities. Pathophysiol. Off. J. Int. Soc. Pathophysiol. 2019, 26, 69-76. [CrossRef]

233. Dutra, R.C.; Claudino, R.F.; Bento, A.F.; Marcon, R.; Schmidt, E.C.; Bouzon, Z.L.; Pianowski, L.F.; Calixto, J.B. Preventive and therapeutic euphol treatment attenuates experimental colitis in mice. PLoS ONE 2011, 6, e27122. [CrossRef]

234. Dutra, R.C.; de Souza, P.R.; Bento, A.F.; Marcon, R.; Bicca, M.A.; Pianowski, L.F.; Calixto, J.B. Euphol prevents experimental autoimmune encephalomyelitis in mice: Evidence for the underlying mechanisms. Biochem. Pharmacol. 2012, 83, 531-542. [CrossRef]

235. Yasukawa, K.; Akihisa, T.; Yoshida, Z.Y.; Takido, M. Inhibitory effect of euphol, a triterpene alcohol from the roots of Euphorbia kansui, on tumour promotion by 12-O-tetradecanoylphorbol-13-acetate in two-stage carcinogenesis in mouse skin. J. Pharm. Pharmacol. 2000, 52, 119-124. [CrossRef] [PubMed]

236. Passos, G.F.; Medeiros, R.; Marcon, R.; Nascimento, A.F.; Calixto, J.B.; Pianowski, L.F. The role of PKC/ERK1/2 signaling in the anti-inflammatory effect of tetracyclic triterpene euphol on TPA-induced skin inflammation in mice. Eur. J. Pharmacol. 2013, 698, 413-420. [CrossRef] [PubMed]

237. Dutra, R.C.; Simao da Silva, K.A.; Bento, A.F.; Marcon, R.; Paszcuk, A.F.; Meotti, F.C.; Pianowski, L.F.; Calixto, J.B. Euphol, a tetracyclic triterpene produces antinociceptive effects in inflammatory and neuropathic pain: The involvement of cannabinoid system. Neuropharmacology 2012, 63, 593-605. [CrossRef] [PubMed]

238. Dutra, R.C.; Bicca, M.A.; Segat, G.C.; Silva, K.A.; Motta, E.M.; Pianowski, L.F.; Costa, R.; Calixto, J.B. The antinociceptive effects of the tetracyclic triterpene euphol in inflammatory and neuropathic pain models: The potential role of PKCepsilon. Neuroscience 2015, 303, 126-137. [CrossRef] [PubMed]

239. Yang, C.; Kennes, Y.M.; Lepp, D.; Yin, X.; Wang, Q.; Yu, H.; Yang, C.; Gong, J.; Diarra, M.S. Effects of encapsulated cinnamaldehyde and citral on the performance and cecal microbiota of broilers vaccinated or not vaccinated against coccidiosis. Poult. Sci. 2020, 99, 936-948. [CrossRef]

240. Shi, C.; Song, K.; Zhang, X.; Sun, Y.; Sui, Y.; Chen, Y.; Jia, Z.; Sun, H.; Sun, Z.; Xia, X. Antimicrobial Activity and Possible Mechanism of Action of Citral against Cronobacter sakazakii. PLoS ONE 2016, 11, e0159006. [CrossRef] 
241. Parra-Flores, J.; Cerda-Leal, F.; Contreras, A.; Valenzuela-Riffo, N.; Rodriguez, A.; Aguirre, J. Cronobacter sakazakii and Microbiological Parameters in Dairy Formulas Associated With a Food Alert in Chile. Front. Microbiol. 2018, 9, 1708. [CrossRef]

242. Gupta, P.; Patel, D.K.; Gupta, V.K.; Pal, A.; Tandon, S.; Darokar, M.P. Citral, a monoterpenoid aldehyde interacts synergistically with norfloxacin against methicillin resistant Staphylococcus aureus. Phytomed. Int. J. Phytother. Phytopharm. 2017, 34, 85-96. [CrossRef]

243. Leite, M.C.; Bezerra, A.P.; de Sousa, J.P.; Guerra, F.Q.; Lima Ede, O. Evaluation of Antifungal Activity and Mechanism of Action of Citral against Candida albicans. Evid. Based Complement. Altern. Med. ECAM 2014, 2014, 378280. [CrossRef]

244. Qian, W.; Liu, M.; Fu, Y.; Wang, T.; Zhang, J.; Yang, M.; Sun, Z.; Li, X.; Li, Y. Antimicrobial and Antibiofilm Activities of Citral against Carbapenem-Resistant Enterobacter cloacae. Foodborne Pathog. Dis. 2020. [CrossRef]

245. Fancello, F.; Petretto, G.L.; Marceddu, S.; Venditti, T.; Pintore, G.; Zara, G.; Mannazzu, I.; Budroni, M.; Zara, S. Antimicrobial activity of gaseous Citrus limon var pompia leaf essential oil against Listeria monocytogenes on ricotta salata cheese. Food Microbiol. 2020, 87, 103386. [CrossRef] [PubMed]

246. de Souza, R.C.; da Costa, M.M.; Baldisserotto, B.; Heinzmann, B.M.; Schmidt, D.; Caron, B.O.; Copatti, C.E. Antimicrobial and synergistic activity of essential oils of Aloysia triphylla and Lippia alba against Aeromonas spp. Microb. Pathog. 2017, 113, 29-33. [CrossRef] [PubMed]

247. Adil, M.; Baig, M.H.; Rupasinghe, H.P.V. Impact of Citral and Phloretin, Alone and in Combination, on Major Virulence Traits of Streptococcus pyogenes. Molecules 2019, 24, 4237. [CrossRef] [PubMed]

248. Lulekal, E.; Tesfaye, S.; Gebrechristos, S.; Dires, K.; Zenebe, T.; Zegeye, N.; Feleke, G.; Kassahun, A.; Shiferaw, Y.; Mekonnen, A. Phytochemical analysis and evaluation of skin irritation, acute and sub-acute toxicity of Cymbopogon citratus essential oil in mice and rabbits. Toxicol. Rep. 2019, 6, 1289-1294. [CrossRef]

249. Sharma, S.; Gupta, J.; Habib, S.; Sahu, D. Chemical properties and therapeutic potential of citral, a monoterpene isolated from lemongrass. Med. Chem. 2019. [CrossRef]

250. Shen, Y.; Sun, Z.; Guo, X. Citral inhibits lipopolysaccharide-induced acute lung injury by activating PPAR-gamma. Eur. J. Pharmacol. 2015, 747, 45-51. [CrossRef]

251. Boukhatem, M.N.; Ferhat, M.A.; Kameli, A.; Saidi, F.; Kebir, H.T. Lemon grass (Cymbopogon citratus) essential oil as a potent anti-inflammatory and antifungal drugs. Libyan J. Med. 2014, 9, 25431. [CrossRef]

252. Yang, S.M.; Hua, K.F.; Lin, Y.C.; Chen, A.; Chang, J.M.; Kuoping Chao, L.; Ho, C.L.; Ka, S.M. Citral is renoprotective for focal segmental glomerulosclerosis by inhibiting oxidative stress and apoptosis and activating Nrf2 pathway in mice. PLoS ONE 2013, 8, e74871. [CrossRef]

253. Campos, C.A.; Lima, B.S.; Trindade, G.G.G.; Souza, E.; Mota, D.S.A.; Heimfarth, L.; Quintans, J.S.S.; Quintans-Junior, L.J.; Sussuchi, E.M.; Sarmento, V.H.V.; et al. Anti-hyperalgesic and anti-inflammatory effects of citral with beta-cyclodextrin and hydroxypropyl-beta-cyclodextrin inclusion complexes in animal models. Life Sci. 2019, 229, 139-148. [CrossRef]

254. Song, Y.; Zhao, H.; Liu, J.; Fang, C.; Miao, R. Effects of Citral on Lipopolysaccharide-Induced Inflammation in Human Umbilical Vein Endothelial Cells. Inflammation 2016, 39, 663-671. [CrossRef]

255. Katsukawa, M.; Nakata, R.; Takizawa, Y.; Hori, K.; Takahashi, S.; Inoue, H. Citral, a component of lemongrass oil, activates PPARalpha and gamma and suppresses COX-2 expression. Biochim. Biophys. Acta 2010, 1801, 1214-1220. [CrossRef]

256. Goncalves, E.C.D.; Assis, P.M.; Junqueira, L.A.; Cola, M.; Santos, A.R.S.; Raposo, N.R.B.; Dutra, R.C. Citral Inhibits the Inflammatory Response and Hyperalgesia in Mice: The Role of TLR4, TLR2/Dectin-1, and CB2 Cannabinoid Receptor/ATP-Sensitive K(+) Channel Pathways. J. Nat. Prod. 2020. [CrossRef] [PubMed]

257. Bouzenna, H.; Hfaiedh, N.; Giroux-Metges, M.A.; Elfeki, A.; Talarmin, H. Biological properties of citral and its potential protective effects against cytotoxicity caused by aspirin in the IEC- 6 cells. Biomed. Pharmacother. 2017, 87, 653-660. [CrossRef] [PubMed]

258. Ortiz, M.I.; Ramirez-Montiel, M.L.; Gonzalez-Garcia, M.P.; Ponce-Monter, H.A.; Castaneda-Hernandez, G.; Carino-Cortes, R. The combination of naproxen and citral reduces nociception and gastric damage in rats. Arch. Pharmacal Res. 2010, 33, 1691-1697. [CrossRef] [PubMed] 
259. Sanches, L.J.; Marinello, P.C.; Panis, C.; Fagundes, T.R.; Morgado-Diaz, J.A.; de-Freitas-Junior, J.C.; Cecchini, R.; Cecchini, A.L.; Luiz, R.C. Cytotoxicity of citral against melanoma cells: The involvement of oxidative stress generation and cell growth protein reduction. Tumour Biol. J. Int. Soc. Oncodev. Biol. Med. 2017, 39. [CrossRef] [PubMed]

260. Sheikh, B.Y.; Sarker, M.M.R.; Kamarudin, M.N.A.; Mohan, G. Antiproliferative and apoptosis inducing effects of citral via p53 and ROS-induced mitochondrial-mediated apoptosis in human colorectal HCT116 and HT29 cell lines. Biomed. Pharmacother. 2017, 96, 834-846. [CrossRef] [PubMed]

261. Nordin, N.; Yeap, S.K.; Rahman, H.S.; Zamberi, N.R.; Abu, N.; Mohamad, N.E.; How, C.W.; Masarudin, M.J.; Abdullah, R.; Alitheen, N.B. In vitro cytotoxicity and anticancer effects of citral nanostructured lipid carrier on MDA MBA-231 human breast cancer cells. Sci. Rep. 2019, 9, 1614. [CrossRef]

262. Bayala, B.; Bassole, I.H.N.; Maqdasy, S.; Baron, S.; Simpore, J.; Lobaccaro, J.A. Cymbopogon citratus and Cymbopogon giganteus essential oils have cytotoxic effects on tumor cell cultures. Identification of citral as a new putative anti-proliferative molecule. Biochimie 2018, 153, 162-170. [CrossRef]

263. Zielinska, A.; Martins-Gomes, C.; Ferreira, N.R.; Silva, A.M.; Nowak, I.; Souto, E.B. Anti-inflammatory and anti-cancer activity of citral: Optimization of citral-loaded solid lipid nanoparticles (SLN) using experimental factorial design and LUMiSizer(R). Int. J. Pharm. 2018, 553, 428-440. [CrossRef]

264. Naz, F.; Khan, F.I.; Mohammad, T.; Khan, P.; Manzoor, S.; Hasan, G.M.; Lobb, K.A.; Luqman, S.; Islam, A.; Ahmad, F.; et al. Investigation of molecular mechanism of recognition between citral and MARK4: A newer therapeutic approach to attenuate cancer cell progression. Int. J. Biol. Macromol. 2018, 107 Pt B, 2580-2589. [CrossRef]

265. Voura, M.; Khan, P.; Thysiadis, S.; Katsamakas, S.; Queen, A.; Hasan, G.M.; Ali, S.; Sarli, V.; Hassan, M.I. Probing the Inhibition of Microtubule Affinity Regulating Kinase 4 by N-Substituted Acridones. Sci. Rep. 2019, 9, 1676. [CrossRef] [PubMed]

266. Nigjeh, S.E.; Yeap, S.K.; Nordin, N.; Rahman, H.; Rosli, R. In Vivo Anti-Tumor Effects of Citral on 4T1 Breast Cancer Cells via Induction of Apoptosis and Downregulation of Aldehyde Dehydrogenase Activity. Molecules 2019, 24, 3241. [CrossRef] [PubMed]

267. Dinavahi, S.S.; Bazewicz, C.G.; Gowda, R.; Robertson, G.P. Aldehyde Dehydrogenase Inhibitors for Cancer Therapeutics. Trends Pharmacol. Sci. 2019, 40, 774-789. [CrossRef] [PubMed]

268. Thomas, M.L.; de Antueno, R.; Coyle, K.M.; Sultan, M.; Cruickshank, B.M.; Giacomantonio, M.A.; Giacomantonio, C.A.; Duncan, R.; Marcato, P. Citral reduces breast tumor growth by inhibiting the cancer stem cell marker ALDH1A3. Mol. Oncol. 2016, 10, 1485-1496. [CrossRef] [PubMed]

269. Nordin, N.; Yeap, S.K.; Zamberi, N.R.; Abu, N.; Mohamad, N.E.; Rahman, H.S.; How, C.W.; Masarudin, M.J.; Abdullah, R.; Alitheen, N.B. Characterization and toxicity of citral incorporated with nanostructured lipid carrier. PeerJ 2018, 6, e3916. [CrossRef]

270. Maruoka, T.; Kitanaka, A.; Kubota, Y.; Yamaoka, G.; Kameda, T.; Imataki, O.; Dobashi, H.; Bandoh, S.; Kadowaki, N.; Tanaka, T. Lemongrass essential oil and citral inhibit Src/Stat3 activity and suppress the proliferation/survival of small-cell lung cancer cells, alone or in combination with chemotherapeutic agents. Int. J. Oncol. 2018, 52, 1738-1748. [CrossRef]

271. Fang, Z.; Wang, Y.; Li, H.; Yu, S.; Liu, Z.; Fan, Z.; Chen, X.; Wu, Y.; Pan, X.; Li, X.; et al. Combination Treatment of Citral Potentiates the Efficacy of Hyperthermic Intraperitoneal Chemoperfusion with Pirarubicin for Colorectal Cancer. Mol. Pharm. 2017, 14, 3588-3597. [CrossRef]

272. Kremer, J.L.; Melo, G.P.; Marinello, P.C.; Bordini, H.P.; Rossaneis, A.C.; Sabio, L.R.; Cecchini, R.; Cecchini, A.L.; Verri, W.A., Jr.; Luiz, R.C. Citral prevents UVB-induced skin carcinogenesis in hairless mice. J. Photochem. Photobiol. Biol. 2019, 198, 111565. [CrossRef]

273. Venkatesha, S.H.; Moudgil, K.D. Celastrol and Its Role in Controlling Chronic Diseases. Adv. Exp. Med. Biol. 2016, 928, 267-289.

274. Law, S.; Leung, A.W.; Xu, C. Folic acid-modified celastrol nanoparticles: Synthesis, characterization, anticancer activity in 2D and 3D breast cancer models. Artif. Cells Nanomed. Biotechnol. 2020, 48, 542-559. [CrossRef]

275. Zhu, B.; Wei, Y. Antitumor activity of celastrol by inhibition of proliferation, invasion, and migration in cholangiocarcinoma via PTEN/PI3K/Akt pathway. Cancer Med. 2020, 9, 783-796. [CrossRef] [PubMed] 
276. Allison, A.C.; Cacabelos, R.; Lombardi, V.R.; Alvarez, X.A.; Vigo, C. Celastrol, a potent antioxidant and anti-inflammatory drug, as a possible treatment for Alzheimer's disease. Prog. Neuro-Psychopharmacol. Biol. Psychiatry 2001, 25, 1341-1357. [CrossRef]

277. Wang, H.; Ahn, K.S.; Alharbi, S.A.; Shair, O.H.; Arfuso, F.; Sethi, G.; Chinnathambi, A.; Tang, F.R. Celastrol Alleviates Gamma Irradiation-Induced Damage by Modulating Diverse Inflammatory Mediators. Int. J. Mol. Sci. 2020, 21, 1084. [CrossRef] [PubMed]

278. Kim, D.H.; Shin, E.K.; Kim, Y.H.; Lee, B.W.; Jun, J.G.; Park, J.H.; Kim, J.K. Suppression of inflammatory responses by celastrol, a quinone methide triterpenoid isolated from Celastrus regelii. Eur. J. Clin. Investig. 2009, 39, 819-827. [CrossRef]

279. Venkatesha, S.H.; Yu, H.; Rajaiah, R.; Tong, L.; Moudgil, K.D. Celastrus-derived celastrol suppresses autoimmune arthritis by modulating antigen-induced cellular and humoral effector responses. J. Biol. Chem. 2011, 286, 15138-15146. [CrossRef]

280. Li, H.; Yuan, Y.; Zhang, Y.; He, Q.; Xu, R.; Ge, F.; Wu, C. Celastrol inhibits IL-1beta-induced inflammation in orbital fibroblasts through the suppression of NF-кB activity. Mol. Med. Rep. 2016, 14, 2799-2806. [CrossRef]

281. Paris, D.; Ganey, N.J.; Laporte, V.; Patel, N.S.; Beaulieu-Abdelahad, D.; Bachmeier, C.; March, A.; Ait-Ghezala, G.; Mullan, M.J. Reduction of beta-amyloid pathology by celastrol in a transgenic mouse model of Alzheimer's disease. J. Neuroinflamm. 2010, 7, 17. [CrossRef]

282. Shrivastava, S.; Jeengar, M.K.; Reddy, V.S.; Reddy, G.B.; Naidu, V.G. Anticancer effect of celastrol on human triple negative breast cancer: Possible involvement of oxidative stress, mitochondrial dysfunction, apoptosis and PI3K/Akt pathways. Exp. Mol. Pathol. 2015, 98, 313-327. [CrossRef]

283. Nagase, M.; Oto, J.; Sugiyama, S.; Yube, K.; Takaishi, Y.; Sakato, N. Apoptosis induction in HL-60 cells and inhibition of topoisomerase II by triterpene celastrol. Biosci. Biotechnol. Biochem. 2003, 67, 1883-1887. [CrossRef]

284. Yu, X.; Ruan, X.; Zhang, J.; Zhao, Q. Celastrol Induces Cell Apoptosis and Inhibits the Expression of the AML1-ETO/C-KIT Oncoprotein in t(8;21) Leukemia. Molecules 2016, 21, 574. [CrossRef]

285. Hsieh, M.J.; Wang, C.W.; Lin, J.T.; Chuang, Y.C.; Hsi, Y.T.; Lo, Y.S.; Lin, C.C.; Chen, M.K. Celastrol, a plant-derived triterpene, induces cisplatin-resistance nasopharyngeal carcinoma cancer cell apoptosis though ERK1/2 and p38 MAPK signaling pathway. Phytomed. Int. J. Phytother. Phytopharm. 2019, 58, 152805. [CrossRef] [PubMed]

286. Liu, Z.; Ma, L.; Wen, Z.S.; Hu, Z.; Wu, F.Q.; Li, W.; Liu, J.; Zhou, G.B. Cancerous inhibitor of PP2A is targeted by natural compound celastrol for degradation in non-small-cell lung cancer. Carcinogenesis 2014, 35, 905-914. [CrossRef] [PubMed]

287. Kannaiyan, R.; Manu, K.A.; Chen, L.; Li, F.; Rajendran, P.; Subramaniam, A.; Lam, P.; Kumar, A.P.; Sethi, G. Celastrol inhibits tumor cell proliferation and promotes apoptosis through the activation of c-Jun N-terminal kinase and suppression of PI3 K/Akt signaling pathways. Apoptosis: Int. J. Program. Cell Death 2011, 16, 1028-1041. [CrossRef] [PubMed]

288. Kiaei, M.; Kipiani, K.; Petri, S.; Chen, J.; Calingasan, N.Y.; Beal, M.F. Celastrol blocks neuronal cell death and extends life in transgenic mouse model of amyotrophic lateral sclerosis. Neuro-Degener. Dis. 2005, 2, $246-254$. [CrossRef]

289. Chow, A.M.; Tang, D.W.; Hanif, A.; Brown, I.R. Localization of heat shock proteins in cerebral cortical cultures following induction by celastrol. Cell Stress Chaperones 2014, 19, 845-851. [CrossRef]

290. Hou, W.; Liu, B.; Xu, H. Celastrol: Progresses in structure-modifications, structure-activity relationships, pharmacology and toxicology. Eur. J. Med. Chem. 2020, 189, 112081. [CrossRef]

291. Leonti, M.; Casu, L.; Raduner, S.; Cottiglia, F.; Floris, C.; Altmann, K.H.; Gertsch, J. Falcarinol is a covalent cannabinoid CB1 receptor antagonist and induces pro-allergic effects in skin. Biochem. Pharmacol. 2010, 79, 1815-1826. [CrossRef]

292. Kobaek-Larsen, M.; Nielsen, D.S.; Kot, W.; Krych, L.; Christensen, L.P.; Baatrup, G. Effect of the dietary polyacetylenes falcarinol and falcarindiol on the gut microbiota composition in a rat model of colorectal cancer. BMC Res. Notes 2018, 11, 411. [CrossRef]

293. Stefanson, A.L.; Bakovic, M. Falcarinol Is a Potent Inducer of Heme Oxygenase-1 and Was More Effective than Sulforaphane in Attenuating Intestinal Inflammation at Diet-Achievable Doses. Oxidative Med. Cell. Longev. 2018, 2018, 3153527. [CrossRef] 
294. Yamauchi, T.; Kadowaki, T. Physiological and pathophysiological roles of adiponectin and adiponectin receptors in the integrated regulation of metabolic and cardiovascular diseases. Int. J. Obes. 2008, 32 (Suppl. 7), S13-S18. [CrossRef]

295. Takagi, M.; Kimura, K.; Nakashima, K.I.; Inoue, M. Ameliorative effect of panaxynol on the reduction in high-molecular-weight adiponectin secretion from 3T3-L1 adipocytes treated with palmitic acids. Eur. J. Pharmacol. 2018, 820, 138-145. [CrossRef] [PubMed]

296. Yu, L.C. Microbiota dysbiosis and barrier dysfunction in inflammatory bowel disease and colorectal cancers: Exploring a common ground hypothesis. J. Biomed. Sci. 2018, 25, 79. [CrossRef] [PubMed]

297. Kho, Z.Y.; Lal, S.K. The Human Gut Microbiome-A Potential Controller of Wellness and Disease. Front. Microbiol. 2018, 9, 1835. [CrossRef] [PubMed]

298. Kobaek-Larsen, M.; El-Houri, R.B.; Christensen, L.P.; Al-Najami, I.; Frette, X.; Baatrup, G. Dietary polyacetylenes, falcarinol and falcarindiol, isolated from carrots prevents the formation of neoplastic lesions in the colon of azoxymethane-induced rats. Food Funct. 2017, 8, 964-974. [CrossRef]

299. Kobaek-Larsen, M.; Baatrup, G.; KhataeiNotabi, M.; El-Houri, R.B.; Pipo-Olle, E.; Christensen Arnspang, E.; Christensen, L.P. Dietary Polyacetylenic Oxylipins Falcarinol and Falcarindiol Prevent Inflammation and Colorectal Neoplastic Transformation: A Mechanistic and Dose-Response Study in A Rat Model. Nutrients 2019, 11, 2223. [CrossRef]

300. Moharil, R.B.; Dive, A.; Khandekar, S.; Bodhade, A. Cancer stem cells: An insight. J. Oral Maxillofac. Pathol. JOMFP 2017, 21, 463. [CrossRef]

301. Zappa, C.; Mousa, S.A. Non-small cell lung cancer: Current treatment and future advances. Transl. Lung Cancer Res. 2016, 5, 288-300. [CrossRef]

302. Trepel, J.; Mollapour, M.; Giaccone, G.; Neckers, L. Targeting the dynamic HSP90 complex in cancer. Nat. Rev. Cancer 2010, 10, 537-549. [CrossRef]

303. Yan, Z.; Yang, R.; Jiang, Y.; Yang, Z.; Yang, J.; Zhao, Q.; Lu, Y. Induction of apoptosis in human promyelocytic leukemia HL60 cells by panaxynol and panaxydol. Molecules 2011, 16, 5561-5573. [CrossRef]

304. Henderson, S.K.; Cohen, H. Nalbuphine augmentation of analgesia and reversal of side effects following epidural hydromorphone. Anesthesiology 1986, 65, 216-218. [CrossRef]

305. Wang, Z.J.; Song, L.; Guo, L.C.; Yin, M.; Sun, Y.N. Induction of differentiation by panaxydol in human hepatocarcinoma SMMC-7721 cells via cAMP and MAP kinase dependent mechanism. Yakugaku Zasshi: J. Pharm. Soc. Jpn. 2011, 131, 993-1000. [CrossRef] [PubMed]

306. Sohn, J.; Lee, C.H.; Chung, D.J.; Park, S.H.; Kim, I.; Hwang, W.I. Effect of petroleum ether extract of Panax ginseng roots on proliferation and cell cycle progression of human renal cell carcinoma cells. Exp. Mol. Med. 1998, 30, 47-51. [CrossRef] [PubMed]

307. Hai, J.; Lin, Q.; Lu, Y.; Yi, J.; Zhang, H. Growth inhibition and induction of differentiation by panaxydol in rat C6 glioma cells. Neurol. Res. 2008, 30, 99-105. [CrossRef] [PubMed]

308. Machado, S.; Silva, E.; Massa, A. Occupational allergic contact dermatitis from falcarinol. Contact Dermat. 2002, 47, 113-114. [CrossRef]

309. Qu, C.; Li, B.; Lai, Y.; Li, H.; Windust, A.; Hofseth, L.J.; Nagarkatti, M.; Nagarkatti, P.; Wang, X.L.; Tang, D.; et al. Identifying panaxynol, a natural activator of nuclear factor erythroid-2 related factor 2 (Nrf2) from American ginseng as a suppressor of inflamed macrophage-induced cardiomyocyte hypertrophy. J. Ethnopharmacol. 2015, 168, 326-336. [CrossRef]

310. Phinney, S.D.; Tang, A.B.; Waggoner, C.R.; Tezanos-Pinto, R.G.; Davis, P.A. The transient hypercholesterolemia of major weight loss. Am. J. Clin. Nutr. 1991, 53, 1404-1410. [CrossRef]

311. MacLean, K.A.; Johnson, M.W.; Reissig, C.J.; Prisinzano, T.E.; Griffiths, R.R. Dose-related effects of salvinorin A in humans: Dissociative, hallucinogenic, and memory effects. Psychopharmacology 2013, 226, 381-392. [CrossRef]

312. Roach, J.J.; Shenvi, R.A. A review of salvinorin analogs and their kappa-opioid receptor activity. Bioorganic Med. Chem. Lett. 2018, 28, 1436-1445. [CrossRef]

313. Walentiny, D.M.; Vann, R.E.; Warner, J.A.; King, L.S.; Seltzman, H.H.; Navarro, H.A.; Twine, C.E., Jr.; Thomas, B.F.; Gilliam, A.F.; Gilmour, B.P.; et al. Kappa opioid mediation of cannabinoid effects of the potent hallucinogen, salvinorin A, in rodents. Psychopharmacology 2010, 210, 275-284. [CrossRef] 
314. Coffeen, U.; Canseco-Alba, A.; Simon-Arceo, K.; Almanza, A.; Mercado, F.; Leon-Olea, M.; Pellicer, F. Salvinorin A reduces neuropathic nociception in the insular cortex of the rat. Eur. J. Pain 2018, 22, 311-318. [CrossRef]

315. Guida, F.; Luongo, L.; Aviello, G.; Palazzo, E.; De Chiaro, M.; Gatta, L.; Boccella, S.; Marabese, I.; Zjawiony, J.K.; Capasso, R.; et al. Salvinorin A reduces mechanical allodynia and spinal neuronal hyperexcitability induced by peripheral formalin injection. Mol. Pain 2012, 8, 60. [CrossRef] [PubMed]

316. Butelman, E.R.; Prisinzano, T.E.; Deng, H.; Rus, S.; Kreek, M.J. Unconditioned behavioral effects of the powerful kappa-opioid hallucinogen salvinorin A in nonhuman primates: Fast onset and entry into cerebrospinal fluid. J. Pharmacol. Exp. Ther. 2009, 328, 588-597. [CrossRef] [PubMed]

317. Prisinzano, T.E. Psychopharmacology of the hallucinogenic sage Salvia divinorum. Life Sci. 2005, 78, 527-531. [CrossRef] [PubMed]

318. Ranganathan, M.; Schnakenberg, A.; Skosnik, P.D.; Cohen, B.M.; Pittman, B.; Sewell, R.A.; D'Souza, D.C. Dose-related behavioral, subjective, endocrine, and psychophysiological effects of the kappa opioid agonist Salvinorin A in humans. Biol. Psychiatry 2012, 72, 871-879. [CrossRef] [PubMed]

319. Paton, K.F.; Kumar, N.; Crowley, R.S.; Harper, J.L.; Prisinzano, T.E.; Kivell, B.M. The analgesic and anti-inflammatory effects of Salvinorin A analogue beta-tetrahydropyran Salvinorin B in mice. Eur. J. Pain 2017, 21, 1039-1050. [CrossRef]

320. Kivell, B.M.; Paton, K.F.; Kumar, N.; Morani, A.S.; Culverhouse, A.; Shepherd, A.; Welsh, S.A.; Biggerstaff, A.; Crowley, R.S.; Prisinzano, T.E. Kappa Opioid Receptor Agonist Mesyl Sal B Attenuates Behavioral Sensitization to Cocaine with Fewer Aversive Side-Effects than Salvinorin A in Rodents. Molecules 2018, 23, 2602. [CrossRef]

321. Zhou, Y.; Crowley, R.; Prisinzano, T.; Kreek, M.J. Effects of mesyl salvinorin B alone and in combination with naltrexone on alcohol deprivation effect in male and female mice. Neurosci. Lett. 2018, 673, 19-23. [CrossRef]

322. Salaga, M.; Polepally, P.R.; Zakrzewski, P.K.; Cygankiewicz, A.; Sobczak, M.; Kordek, R.; Zjawiony, J.K.; Krajewska, W.M.; Fichna, J. Novel orally available salvinorin A analog PR-38 protects against experimental colitis and reduces abdominal pain in mice by interaction with opioid and cannabinoid receptors. Biochem. Pharmacol. 2014, 92, 618-626. [CrossRef]

323. Wang, Z.; Ma, N.; Riley, J.; Armstead, W.M.; Liu, R. Salvinorin A administration after global cerebral hypoxia/ischemia preserves cerebrovascular autoregulation via kappa opioid receptor in piglets. PLoS ONE 2012, 7, e41724. [CrossRef]

324. Su, D.; Riley, J.; Armstead, W.M.; Liu, R. Salvinorin A pretreatment preserves cerebrovascular autoregulation after brain hypoxic/ischemic injury via extracellular signal-regulated kinase/mitogen-activated protein kinase in piglets. Anesth. Analg. 2012, 114, 200-204. [CrossRef]

325. Xin, J.; Zhang, Y.; He, Z.; Wang, Z. Highly selective non-opioid kappa opioid receptor (KOR) agonist salvinorin A protects against forebrain ischemia-induced brain injury in rats. Brain Res. 2016, 1637, 168-176. [CrossRef] [PubMed]

326. Sun, J.; Zhang, Y.; Lu, J.; Zhang, W.; Yan, J.; Yang, L.; Zhou, C.; Liu, R.; Chen, C. Salvinorin A ameliorates cerebral vasospasm through activation of endothelial nitric oxide synthase in a rat model of subarachnoid hemorrhage. Microcirculation 2018, 25, e12442. [CrossRef] [PubMed]

327. Dong, H.; Zhou, W.; Xin, J.; Shi, H.; Yao, X.; He, Z.; Wang, Z. Salvinorin A moderates postischemic brain injury by preserving endothelial mitochondrial function via AMPK/Mfn2 activation. Exp. Neurol. 2019, 322, 113045. [CrossRef]

328. Tang, G.; Yang, G.Y. Aquaporin-4: A Potential Therapeutic Target for Cerebral Edema. Int. J. Mol. Sci. 2016, 17, 1413. [CrossRef]

329. Braida, D.; Capurro, V.; Zani, A.; Rubino, T.; Vigano, D.; Parolaro, D.; Sala, M. Potential anxiolytic- and antidepressant-like effects of salvinorin A, the main active ingredient of Salvia divinorum, in rodents. Br. J. Pharmacol. 2009, 157, 844-853. [CrossRef] [PubMed]

330. Ebner, S.R.; Roitman, M.F.; Potter, D.N.; Rachlin, A.B.; Chartoff, E.H. Depressive-like effects of the kappa opioid receptor agonist salvinorin A are associated with decreased phasic dopamine release in the nucleus accumbens. Psychopharmacology 2010, 210, 241-252. [CrossRef]

331. Kivell, B.; Uzelac, Z.; Sundaramurthy, S.; Rajamanickam, J.; Ewald, A.; Chefer, V.; Jaligam, V.; Bolan, E.; Simonson, B.; Annamalai, B.; et al. Salvinorin A regulates dopamine transporter function via a kappa opioid receptor and ERK1/2-dependent mechanism. Neuropharmacology 2014, 86, 228-240. [CrossRef] 
332. Keasling, A.W.; Pandey, P.; Doerksen, R.J.; Pedrino, G.R.; Costa, E.A.; da Cunha, L.C.; Zjawiony, J.K.; Fajemiroye, J.O. Salvindolin elicits opioid system-mediated antinociceptive and antidepressant-like activities. J. Psychopharmacol. 2019, 33, 865-881. [CrossRef]

333. Fajemiroye, J.O.; Prabhakar, P.R.; Cunha, L.C.; Costa, E.A.; Zjawiony, J.K. 22-azidosalvinorin A exhibits antidepressant-like effect in mice. Eur. J. Pharmacol. 2017, 800, 96-106. [CrossRef]

334. Rossi, A.; Caiazzo, E.; Bilancia, R.; Riemma, M.A.; Pagano, E.; Cicala, C.; Ialenti, A.; Zjawiony, J.K.; Izzo, A.A.; Capasso, R.; et al. Salvinorin A Inhibits Airway Hyperreactivity Induced by Ovalbumin Sensitization. Front. Pharmacol. 2016, 7, 525. [CrossRef]

335. Salaga, M.; Polepally, P.R.; Zielinska, M.; Marynowski, M.; Fabisiak, A.; Murawska, N.; Sobczak, K.; Sacharczuk, M.; Do Rego, J.C.; Roth, B.L.; et al. Salvinorin A analogues PR-37 and PR-38 attenuate compound 48/80-induced itch responses in mice. Br. J. Pharmacol. 2015, 172, 4331-4341. [CrossRef] [PubMed]

336. Gertsch, J.; Pertwee, R.G.; Di Marzo, V. Phytocannabinoids beyond the Cannabis plant-Do they exist? Br. J. Pharmacol. 2010, 160, 523-529. [CrossRef] [PubMed]

337. Zhao, Q.; Bi, Y.; Zhong, J.; Ren, Z.; Liu, Y.; Jia, J.; Yu, M.; Tan, Y.; Zhang, Q.; Yu, X. Pristimerin suppresses colorectal cancer through inhibiting inflammatory responses and Wnt/beta-catenin signaling. Toxicol. Appl. Pharmacol. 2020, 386, 114813. [CrossRef] [PubMed]

338. Yousef, B.A.; Hassan, H.M.; Zhang, L.Y.; Jiang, Z.Z. Pristimerin exhibits in vitro and in vivo anticancer activities through inhibition of nuclear factor-small ka, CyrillicB signaling pathway in colorectal cancer cells. Phytomed. Int. J. Phytother. Phytopharm. 2018, 40, 140-147.

339. Slattery, M.L.; Mullany, L.E.; Sakoda, L.; Samowitz, W.S.; Wolff, R.K.; Stevens, J.R.; Herrick, J.S. The NF-кB signalling pathway in colorectal cancer: Associations between dysregulated gene and miRNA expression. J. Cancer Res. Clin. Oncol. 2018, 144, 269-283. [CrossRef]

340. Park, J.H.; Kim, J.K. Pristimerin, a naturally occurring triterpenoid, attenuates tumorigenesis in experimental colitis-associated colon cancer. Phytomed. Int. J. Phytother. Phytopharm. 2018, 42, 164-171. [CrossRef]

341. Grossi, V.; Fasano, C.; Celestini, V.; Lepore Signorile, M.; Sanese, P.; Simone, C. Chasing the FOXO3: Insights into Its New Mitochondrial Lair in Colorectal Cancer Landscape. Cancers 2019, 11, 414. [CrossRef]

342. Liu, Y.; Ao, X.; Ding, W.; Ponnusamy, M.; Wu, W.; Hao, X.; Yu, W.; Wang, Y.; Li, P.; Wang, J. Critical role of FOXO3a in carcinogenesis. Mol. Cancer 2018, 17, 104. [CrossRef]

343. Yousef, B.A.; Hassan, H.M.; Guerram, M.; Hamdi, A.M.; Wang, B.; Zhang, L.Y.; Jiang, Z.Z. Pristimerin inhibits proliferation, migration and invasion, and induces apoptosis in HCT-116 colorectal cancer cells. Biomed. Pharmacother. 2016, 79, 112-119. [CrossRef]

344. Yousef, B.A.; Guerram, M.; Hassan, H.M.; Hamdi, A.M.; Zhang, L.Y.; Jiang, Z.Z. Pristimerin demonstrates anticancer potential in colorectal cancer cells by inducing G1 phase arrest and apoptosis and suppressing various pro-survival signaling proteins. Oncol. Rep. 2016, 35, 1091-1100. [CrossRef]

345. Adams, R.; Brown, E.; Brown, L.; Butler, R.; Falk, S.; Fisher, D.; Kaplan, R.; Quirke, P.; Richman, S.; Samuel, L.; et al. Inhibition of EGFR, HER2, and HER3 signalling in patients with colorectal cancer wild-type for BRAF, PIK3CA, KRAS, and NRAS (FOCUS4-D): A phase 2-3 randomised trial. Lancet. Gastroenterol. Hepatol. 2018, 3, 162-171. [CrossRef]

346. Zhao, Q.; Liu, Y.; Zhong, J.; Bi, Y.; Liu, Y.; Ren, Z.; Li, X.; Jia, J.; Yu, M.; Yu, X. Pristimerin induces apoptosis and autophagy via activation of ROS/ASK1/JNK pathway in human breast cancer in vitro and in vivo. Cell Death Discov. 2019, 5, 125. [CrossRef] [PubMed]

347. Lee, Y.; Na, J.; Lee, M.S.; Cha, E.Y.; Sul, J.Y.; Park, J.B.; Lee, J.S. Combination of pristimerin and paclitaxel additively induces autophagy in human breast cancer cells via ERK1/2 regulation. Mol. Med. Rep. 2018, 18, 4281-4288. [CrossRef] [PubMed]

348. Cevatemre, B.; Erkisa, M.; Aztopal, N.; Karakas, D.; Alper, P.; Tsimplouli, C.; Sereti, E.; Dimas, K.; Armutak, E.I.I.; Gurevin, E.G.; et al. A promising natural product, pristimerin, results in cytotoxicity against breast cancer stem cells in vitro and xenografts in vivo through apoptosis and an incomplete autopaghy in breast cancer. Pharmacol. Res. 2018, 129, 500-514. [CrossRef] [PubMed]

349. Xie, G.; Yu, X.; Liang, H.; Chen, J.; Tang, X.; Wu, S.; Liao, C. Pristimerin overcomes adriamycin resistance in breast cancer cells through suppressing Akt signaling. Oncol. Lett. 2016, 11, 3111-3116. [CrossRef]

350. Lee, J.S.; Yoon, I.S.; Lee, M.S.; Cha, E.Y.; Thuong, P.T.; Diep, T.T.; Kim, J.R. Anticancer activity of pristimerin in epidermal growth factor receptor 2-positive SKBR3 human breast cancer cells. Biol. Pharm. Bull. 2013, 36, 316-325. [CrossRef] 
351. Zhang, B.; Zhang, J.; Pan, J. Pristimerin effectively inhibits the malignant phenotypes of uveal melanoma cells by targeting NFkappaB pathway. Int. J. Oncol. 2017, 51, 887-898. [CrossRef]

352. Mori, Y.; Shirai, T.; Terauchi, R.; Tsuchida, S.; Mizoshiri, N.; Hayashi, D.; Arai, Y.; Kishida, T.; Mazda, O.; Kubo, T. Antitumor effects of pristimerin on human osteosarcoma cells in vitro and in vivo. Oncotargets Ther. 2017, 10, 5703-5710. [CrossRef]

353. Deeb, D.; Gao, X.; Liu, Y.B.; Pindolia, K.; Gautam, S.C. Pristimerin, a quinonemethide triterpenoid, induces apoptosis in pancreatic cancer cells through the inhibition of pro-survival Akt/NF- $\mathrm{kB} / \mathrm{mTOR}$ signaling proteins and anti-apoptotic Bcl-2. Int. J. Oncol. 2014, 44, 1707-1715. [CrossRef]

354. Deeb, D.; Gao, X.; Liu, Y.; Pindolia, K.; Gautam, S.C. Inhibition of hTERT/telomerase contributes to the antitumor activity of pristimerin in pancreatic ductal adenocarcinoma cells. Oncol. Rep. 2015, 34, 518-524. [CrossRef]

355. Lee, S.O.; Kim, J.S.; Lee, M.S.; Lee, H.J. Anti-cancer effect of pristimerin by inhibition of HIF-1alpha involves the SPHK-1 pathway in hypoxic prostate cancer cells. BMC Cancer 2016, 16, 701. [CrossRef] [PubMed]

356. Liu, Y.B.; Gao, X.; Deeb, D.; Pindolia, K.; Gautam, S.C. Role of telomerase in anticancer activity of pristimerin in prostate cancer cells. J. Exp. Ther. Oncol. 2015, 11, 41-49. [PubMed]

357. Liu, Y.B.; Gao, X.; Deeb, D.; Brigolin, C.; Zhang, Y.; Shaw, J.; Pindolia, K.; Gautam, S.C. Ubiquitin-proteasomal degradation of antiapoptotic survivin facilitates induction of apoptosis in prostate cancer cells by pristimerin. Int. J. Oncol. 2014, 45, 1735-1741. [CrossRef] [PubMed]

358. Liu, Y.B.; Gao, X.; Deeb, D.; Arbab, A.S.; Gautam, S.C. Pristimerin Induces Apoptosis in Prostate Cancer Cells by Down-regulating Bcl-2 through ROS-dependent Ubiquitin-proteasomal Degradation Pathway. J. Carcinog. Mutagenesis 2013. [CrossRef]

359. Clark, A.R.; Toker, A. Signalling specificity in the Akt pathway in breast cancer. Biochem. Soc. Trans. 2014, 42, 1349-1355. [CrossRef] [PubMed]

360. Jin, Y.; Huynh, D.T.N.; Kang, K.W.; Myung, C.S.; Heo, K.S. Inhibition of p90RSK activation sensitizes triple-negative breast cancer cells to cisplatin by inhibiting proliferation, migration and EMT. BMB Rep. 2019, 52, 706-711. [CrossRef]

361. Li, Z.; Hu, C.; Zhen, Y.; Pang, B.; Yi, H.; Chen, X. Pristimerin inhibits glioma progression by targeting AGO2 and PTPN1 expression via miR-542-5p. Biosci. Rep. 2019, 39. [CrossRef]

362. Ye, Z.; Jin, H.; Qian, Q. Argonaute 2: A Novel Rising Star in Cancer Research. J. Cancer 2015, 6, 877-882. [CrossRef]

363. Liu, J.; Luan, W.; Zhang, Y.; Gu, J.; Shi, Y.; Yang, Y.; Feng, Z.; Qi, F. HDAC6 interacts with PTPN1 to enhance melanoma cells progression. Biochem. Biophys. Res. Commun. 2018, 495, 2630-2636. [CrossRef]

364. Zhao, H.; Wang, C.; Lu, B.; Zhou, Z.; Jin, Y.; Wang, Z.; Zheng, L.; Liu, K.; Luo, T.; Zhu, D.; et al. Pristimerin triggers AIF-dependent programmed necrosis in glioma cells via activation of JNK. Cancer Lett. 2016, 374, 136-148. [CrossRef]

365. Yan, Y.Y.; Bai, J.P.; Xie, Y.; Yu, J.Z.; Ma, C.G. The triterpenoid pristimerin induces U87 glioma cell apoptosis through reactive oxygen species-mediated mitochondrial dysfunction. Oncol. Lett. 2013, 5, 242-248. [CrossRef] [PubMed]

366. Thomas, R.; Weihua, Z. Rethink of EGFR in Cancer with Its Kinase Independent Function on Board. Front. Oncol. 2019, 9, 800. [CrossRef] [PubMed]

367. Wu, H.; Li, L.; Ai, Z.; Yin, J.; Chen, L. Pristimerin induces apoptosis of oral squamous cell carcinoma cells via G1 phase arrest and MAPK/Erk1/2 and Akt signaling inhibition. Oncol. Lett. 2019, 17, 3017-3025. [CrossRef] [PubMed]

368. Gao, X.; Liu, Y.; Deeb, D.; Arbab, A.S.; Gautam, S.C. Anticancer activity of pristimerin in ovarian carcinoma cells is mediated through the inhibition of prosurvival Akt/NF-kB/mTOR signaling. J. Exp. Ther. Oncol. 2014, 10, 275-283.

369. Cuvillier, O.; Ader, I. Hypoxia-inducible factors and sphingosine 1-phosphate signaling. Anti-Cancer Agents Med. Chem. 2011, 11, 854-862. [CrossRef]

370. Yang, H.; Landis-Piwowar, K.R.; Lu, D.; Yuan, P.; Li, L.; Reddy, G.P.; Yuan, X.; Dou, Q.P. Pristimerin induces apoptosis by targeting the proteasome in prostate cancer cells. J. Cell. Biochem. 2008, 103, 234-244. [CrossRef]

371. Wei, X.; Zeng, W.; Xie, K.; Diao, P.; Tang, P. Potential use of chymotrypsin-like proteasomal activity as a biomarker for prostate cancer. Oncol. Lett. 2018, 15, 5149-5154. [CrossRef] 
372. Tong, L.; Nanjundaiah, S.M.; Venkatesha, S.H.; Astry, B.; Yu, H.; Moudgil, K.D. Pristimerin, a naturally occurring triterpenoid, protects against autoimmune arthritis by modulating the cellular and soluble immune mediators of inflammation and tissue damage. Clin. Immunol. 2014, 155, 220-230. [CrossRef]

373. Kim, H.J.; Park, G.M.; Kim, J.K. Anti-inflammatory effect of pristimerin on lipopolysaccharide-induced inflammatory responses in murine macrophages. Arch. Pharmacal Res. 2013, 36, 495-500. [CrossRef] 